\title{
AQUIFER-SYSTEM COMPACTION, TUCSON BASIN AND AVRA VALLEY, ARIZONA
}

by

Randa11 Tyler Hanson

\author{
A Thesis Submitted to the Faculty of the \\ DEPARTMENT OF HYDROLOGY AND WATER RESOURCES \\ In Partial Fulfillment of the Requirements \\ For the Degree of \\ MASTER OF SCIENCE \\ WITH A MAJOR IN HYDROLOGY \\ In the Graduate College \\ THE UNIVERSITY OF ARIZONA
}

1988 


\section{STATEMENT BY AUTHOR}

This thesis has been submitted in partial fulfillment of requirements for an advanced degree at The University of Arizona and is deposited in the University Library to be made available to borrowers under rules of the library.

Brief quotations from this thesis are allowable without special permission, provided that accurate acknowledgment of source is made. Requests for permission for extended quotation from or reproduction of this manuscript in whole or in part may be granted by the head of the major department or the Dean of the Graduate College when in his or her judgment the proposed use of the material is in the interest of scholarship. In all other instances, however, permission must be obtained from the author.

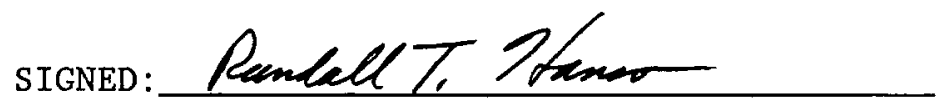

\section{APPROVAL BY THE THESIS DIRECTOR}

This thesis has been approved on the date shown below:

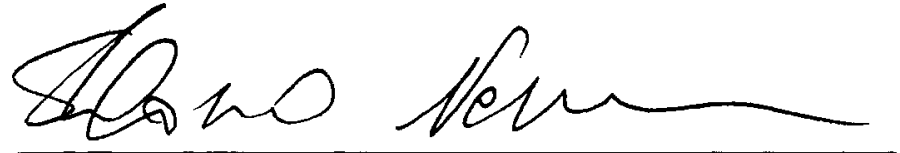

Shlomo P. Neuman

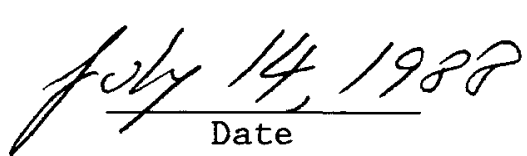




\section{ACKNOWLEDGMENTS}

The writer acknowledges the cooperation of the City of Tucson, Arizona Bureau of Geology, and Arizona Department of Water Resources for collection of data used in this report. Technical support was also provided by Stan Leake and Michael Carpenter of the Survey's R.A.S.A. Subsidence Research Project, and Steve Anderson and Francis Riley of the U. S. Geological Survey. The writer also acknowledges the helpful technical guidance by Dr. S. P. Neuman and the faith and support of my family to whom I dedicate this thesis. 
TABLE OF CONTENTS

Page

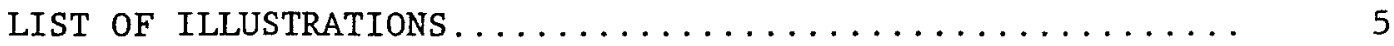

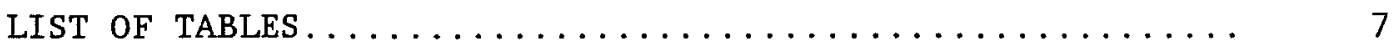

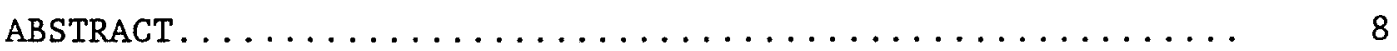

1. INTRODUCTION $\ldots \ldots \ldots \ldots \ldots \ldots \ldots \ldots \ldots \ldots \ldots \ldots \ldots \ldots \ldots$

1.1 Previous Studies.................... 11

1.2 Physical Setting...................... 12

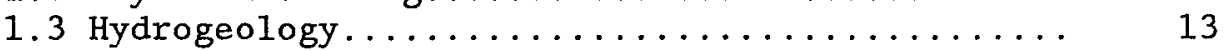

1.4 Extensometer-Data Collection............ 20

2. COMPONENTS OF AQUIFER-SYSTEM COMPACTION........... 25

2.1 One-Dimensional Compaction............ 26

2. 2 Preconsolidation Stress................ 34

2.3 Components of Storage............... 36

2.4 Geometric Properties................. 40

3. AQUIFER-SYSTEM COMPACTION.................. 44

3.1 Extensometers in Tucson Basin............ 45

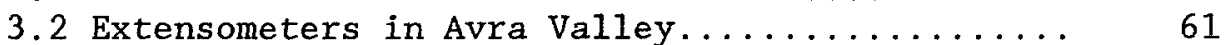

3.3 Observed Stress and Compaction............ 65

4. SIMULATION OF AQUIFER-SYSTEM COMPACTION........... 75

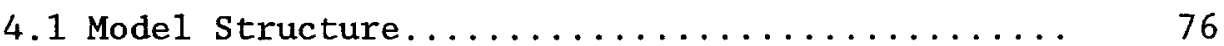

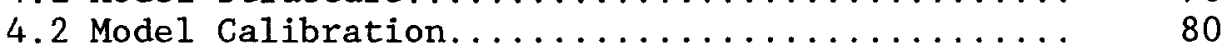

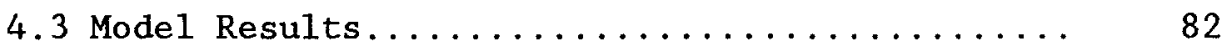

4.4 Sensitivity Analysis................ 85

5. SUMMARY $\ldots \ldots \ldots \ldots \ldots \ldots \ldots \ldots \ldots \ldots \ldots \ldots \ldots \ldots \ldots \ldots$

LIST OF REFERENCES $\ldots \ldots \ldots \ldots \ldots \ldots \ldots \ldots \ldots \ldots \ldots \ldots \ldots \ldots \ldots \ldots$ 
LIST OF ILLUSTRATIONS

Figure

Page

1. Area of report..................... 10

2. Vertical extensometers, piezometers, and selected observation wells, Tucson basin and Avra

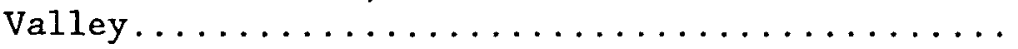

3. Long-term hydrogxaphs for wells near extensometer sites, Tucson basin and Avra Valley...........

4. Depth to water in piezometers, Tucson basin......

5. Typical vertical-extensometer installation in Tucson basin and Avra Valley..............

6. Generalized stress diagram for aquifer system with head reduction for equivalent-system simulation of a combined water-table and confined aquifer system prior to re-establishment of hydrostatic

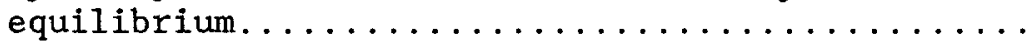

7. Idealized stress-mean strain relation on linear coordinates for a saturated volume element of

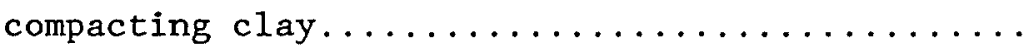

8. Depth to water, measured and simulated compaction, and simulation error in well SC-30,

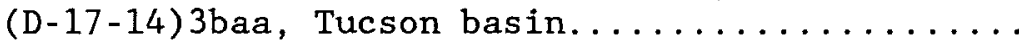

9. Grain-size distribution and hydrologic summary for wel1 SC-30, (D-17-14)3baa, Tucson basin........

10. Measured stress versus compaction in well SC-30,

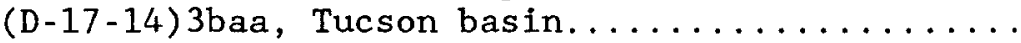

11. Depth to water, measured and simulated compaction, and simulation error in well $\mathrm{SC}-17$,

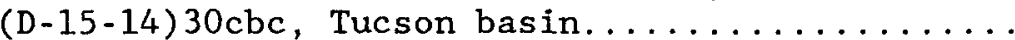

12. Grain-size distribution and hydrologic summary for we11 SC-17, (D-15-14)30cbc, Tucson basin.......

13. Measured stress versus compaction in well $\mathrm{SC}-17$,

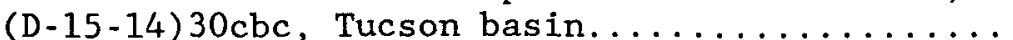

14. Depth to water, measured and simulated compaction, and simulation error in well B-76

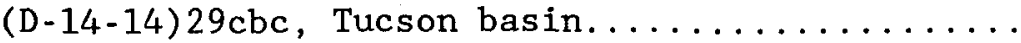




\section{LIST OF ILLUSTRATIONS- Continued}

Figure

Page

15. Grain-size distribution and hydrologic summary for well B-76, (D-14-14) $29 \mathrm{cbc}$, Tucson basin.........

16. Measured stress versus compaction in well B-76,

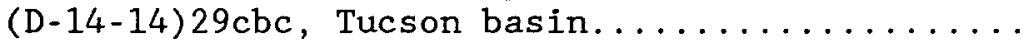

17. Depth to water and measured compaction in wells C-45, (D-14-14) 22adb, and D-61, (D-14-14)23cab,

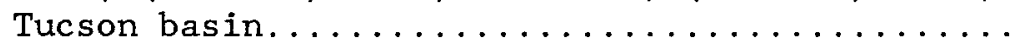

18. Measured stress versus compaction in well $\mathrm{C}-45$, (D-14-14) $22 \mathrm{adb}$, and D-61, (D-14-14) 23cab,

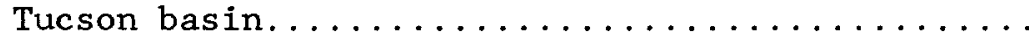

19. Depth to water, measured and simulated compaction, and simulation error in well WR-52,

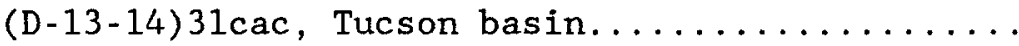

20. Grain-size distribution and hydrologic summary for well WR-52, (D-13-14)31cac, Tucson basin.......

21. Measured stress versus compaction in well WR-52,

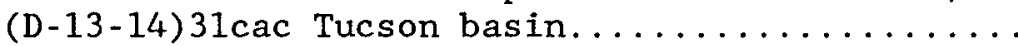

22. Depth to water, measured and simulated compaction, and simulation error in well AF-14,

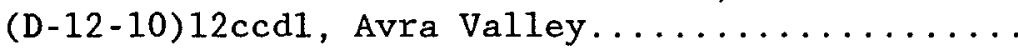

23. Grain-size distribution and hydrologic summary for we11 AF-14 (D-12-10)12ccd1, Avra Valley.........

24. Measured stress versus compaction in well AF-14,

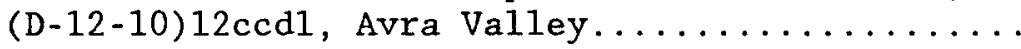

25. Depth to water, measured and simulated compaction, and simulation error in well AV-25,

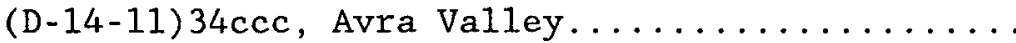

26. Grain-size distribution and hydrologic summary for well AV-25, (D-14-14)34ccc, Avra Valley........

27. Measured stress versus compaction in well AV-25,

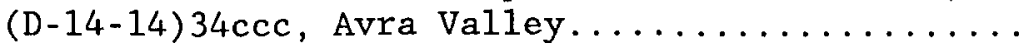


LIST OF TABLES

$\begin{array}{lll}\text { Table Page } & \text { Pas }\end{array}$

1. Summary of aquifer-system storage components and related time constants for selected extensometer sites, Tucson basin and

Avra Valley...................... 47

2. Summary of Helm model aquifer-system components for selected extensometer sites, Tucson basin and Avra Valley............. 84

3. Summary of error sensitivity for selected aquifer-system components............... 


\begin{abstract}
Ground-water declines of several feet per year since the $1940^{\prime}$ 's induced aquifer-system compaction and land subsidence of as much as 0.5 foot in the Tucson basin and 1.1 feet in Avra Valley. Aquifersystem compaction is affected by layering, hydraulic diffusivity, preconsolidation stress, and stress history of the aquifer system. Layering at extensometer sites can be categorized into three general groups that typify the fine- and coarse-grained layering within the Fort Lowel1 Formation and upper Tinaja beds.

A one-dimensional compaction model was used to simulate aquifer-system compaction of less than 0.1 foot. Elastic and some inelastic specific storage values are comparable to previous estimates. Parts of the aquifer systems appear to be in transition from predominantly elastic to inelastic compaction. Water-level declines since 1940 at the six modeled extensometer sites are within an estimated preconsolidation-stress threshold of 50 to 150 feet. The simulations were most sensitive to reduction of initial preconsolidation stress and least sensitive to changes in aquifer specific storage.
\end{abstract}


CHAPTER 1

\section{INTRODUCTION}

Ground water is the main source of water for irrigation, public supply, and industry in Tucson basin and Avra Valley, southeastern Arizona (fig. 1). Since major ground-water development began in the 1940's, pumpage has exceeded recharge in Tucson basin and in Avra Valley. Ground-water withdrawals resulted in water-level declines that in turn caused small amounts of aquifer-system compaction and land subsidence (Anderson, 1987a, 1988). Compaction and subsidence continue in both areas and may cause damage to manmade structures as well as reducing long-term yield to wells. In 1984 the aquifer systems in the Tucson basin and Avra Valley received sole-source designation by the U.S. Environmental Protection Agency in 1984 (U.S. Environmental Protection Agency, 1984). The City of Tucson relies exclusively on ground water for its water supply.

In 1979 the U.S. Geological Survey, in cooperation with the City of Tucson, began to study aquifer compaction and land subsidence in Tucson basin, and in 1983 the study was expanded to include Avra Valley (fig. 1). The study was divided into three phases: (1) a detailed geohydrologic investigation, (2) a stress-strain analysis, and (3) areal subsidence models. 


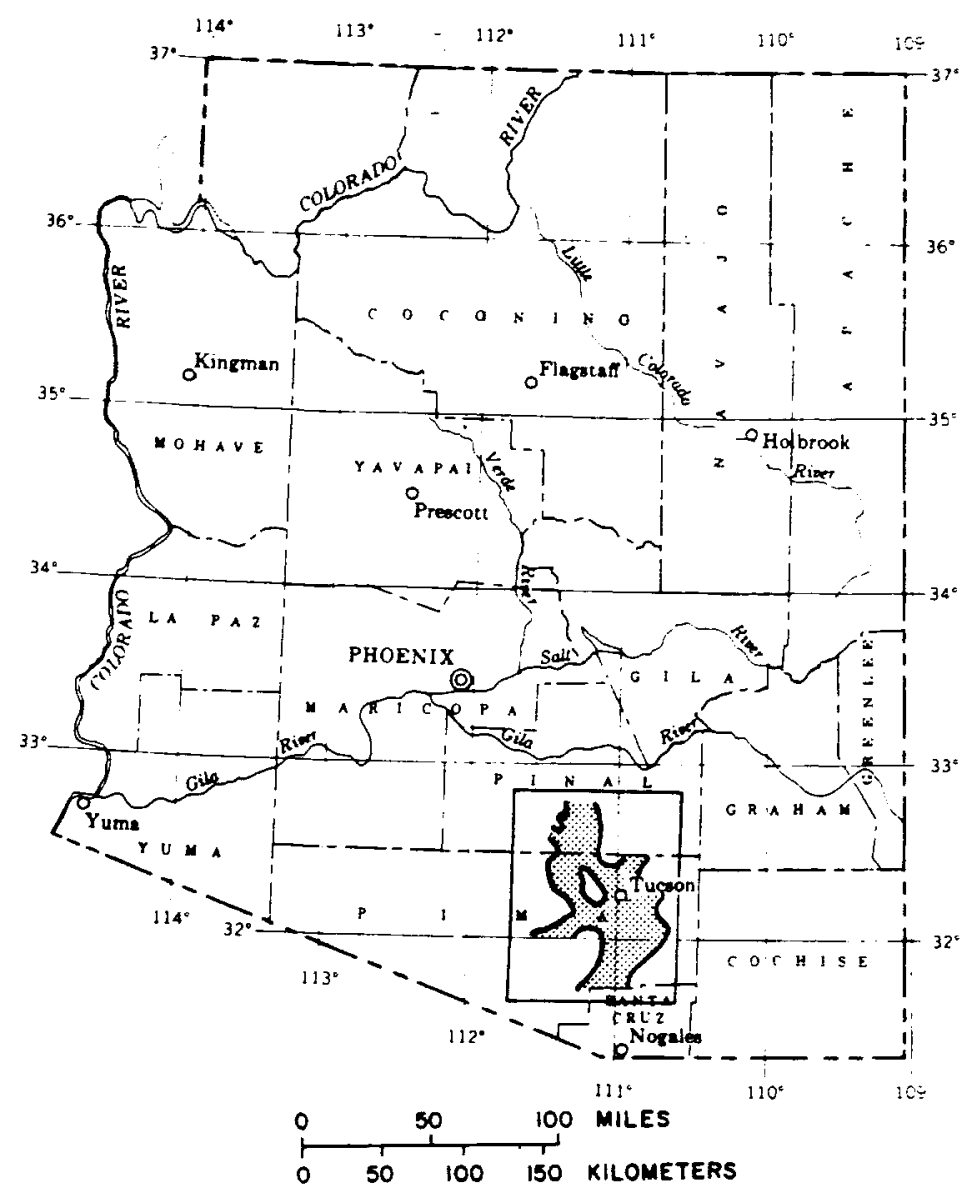

Figure 1.--Area of report (shaded). 
Vertical extensometer installations were completed during the first phase of the investigation (Anderson, 1987a, 1988) to monitor the amount and rate of aquifer-system compaction. The initial phase of the investigation delineated clay and silt distribution within the Fort Lowell Formation and upper Tinaja beds, identified areas of potential and differential subsidence, estimated ultimate compaction, and provided basic data on compaction and subsidence.

The second phase of the investigation was initiated in 1985 to study the relations between aquifer compaction, water-level changes, and sediment layering at six extensometers. Numerical simulations based on extensometer data provided estimates of aquifer-system components needed for areal subsidence models. This report presents a description of the aquifer-system, hydrologic conditions near six extensometer sites, an analysis of extensometer compaction data, and the results of applying a one-dimensional compaction model to data from the six extensometers. The scope of this study was limited to data collected between December 1979 and August 1986.

In the third phase, areal-subsidence models will be used to assess the basin-wide impact of continued ground-water withdrawals on the distribution of aquifer-system compaction and land subsidence. Areal-subsidence models will provide a management tool for assessing the impact of various ground-water withdrawal strategies on aquifersystem compaction and land subsidence.

\subsection{Previous Studies}

Federal, State, county, municipal, and university studies have focused on various aspects of the geohydrologic framework of 
Tucson basin and Avra Valley. Geohydrology and water resources were studied by Davidson (1973), Pool (1984), and Schmidt (1985), and generalized stratigraphy was studied by Oppenheimer and Sumner (1980), Allen (1981), and Anderson (1987b). Laney (1972) studied the chemical quality of water, and streamflow characteristics was studied by Condes de la Torre (1970) and Burkham (1970). Models of ground-water flow were detailed by Anderson (1972), Moosburner (1972), Clifton (1981), and Travers and Mock (1984). Mock and others (1985), Rampe (1985), and Leake and Hanson (1986) studied distribution and movement of trichloroethylene in ground water. The potential for aquifer compaction, land subsidence, and earth fissures was reviewed by Anderson (1987a, 1988), Caito and Sogge (1982), and Platt (1963). General ground-water conditions were defined by white and others (1966), Reeter and Cady (1982), Whallon (1983), and Cuff and Anderson (1987). Babcock and Hix (1982) and Babcock and others (1984, 1986) reported static water levels. Poland and others (1972), Anderson and others (1982), and Laney and Davidson (1986) summarize hydrologic and geologic terms used in this report.

\subsection{Physical Setting}

Tucson basin in Pima County and Avra Valley in Pima and Pinal Counties, southeastern Arizona (fig. 2) are two adjacent alluvial basins in the Basin and Range physiographic province (Fenneman, 1931). Tucson basin is geomorphologically similar to the high-altitude basins to the east that are characterized by high, extensive mountains and steeply sloping valley floors. Avra Valley is similar to basins to the west that are characterized by a higher proportion of alluvial area in 
relation to mountain area, lower surrounding mountain ranges, and less sloping valley floors. Tucson basin is separated from Avra Valley by the Tucson Mountains and Black Mountain.

Tucson basin encompasses about $1,000 \mathrm{mi}^{2}$ in the northcentral part of the upper Santa Cruz River drainage basin. Tucson basin is bounded on the east by the Rincon, Empire, and Tanque Verde Mountains; on the north by the Tortolita and Santa Catalina Mountains; on the west by the Sierrita and Tucson Mountains and Black Mountain; and on the south by the Santa Rita Mountains. These mountains range in altitude from 3,000 to $9,400 \mathrm{ft}$. The valley floor ranges in altitude from 2,000 ft near Rillito at the northwest end of the basin to 3,500 ft near the south end. Annual precipitation ranges from 11 in. on the valley floor to about 30 in. annually in the surrounding mountains. Avra Valley encompasses about $520 \mathrm{mi}^{2}$ and is bounded on the east by the Tucson Mountains; on the northeast by the Tortolita Mountains; on the northwest by Picacho Peak; on the west by the Silverbe11, Waterman, and Roskruge Mountains; and on the south by the Sierrita Mountains and Altar Valley. These mountains range in altitude from about 4,500 ft to $6,000 \mathrm{ft}$. The valley floor ranges from $1,800 \mathrm{ft}$ near Picacho Peak to 2,600 ft near Three Points. Annual precipitation in Avra Valley ranges from less than $10 \mathrm{in.}$ on the valley floor to about 12 in. in the mountains.

\section{$\underline{1.3 \text { Hydrogeology }}$}

Tucson basin and Avra Valley are two north- to northwesttrending alluvial basins bounded by block-faulted mountains that consist of Precambrian to Tertiary igneous, metamorphic, and 
Figure 2.-Vertical extensometers, piezometers, and selected observation wells, Tucson basin and Avra Valley.

\author{
E X P L A N A I I O N
}

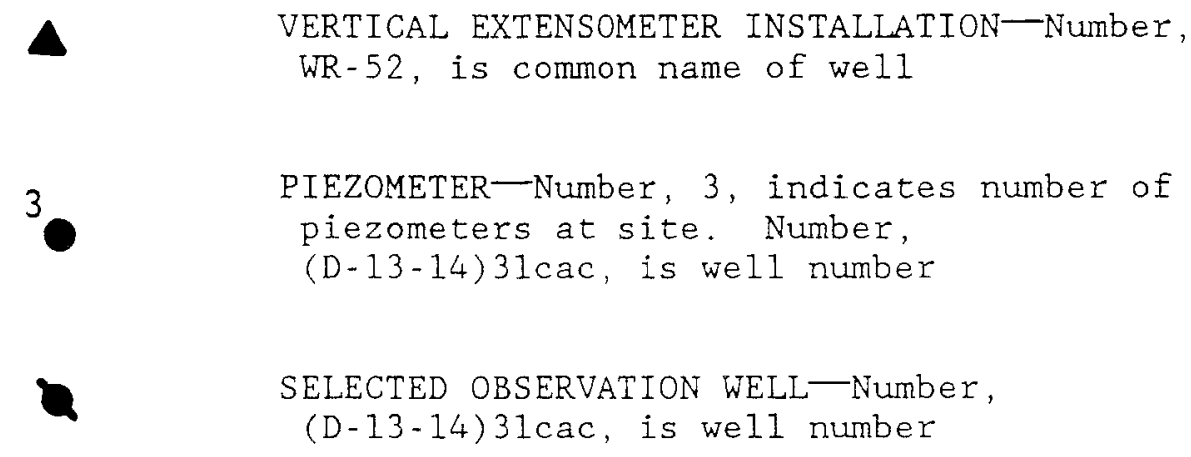

$-\longrightarrow-\cdots$ SUBBASIN BOUNDARY

BOUNDARY OF AQUIFER 


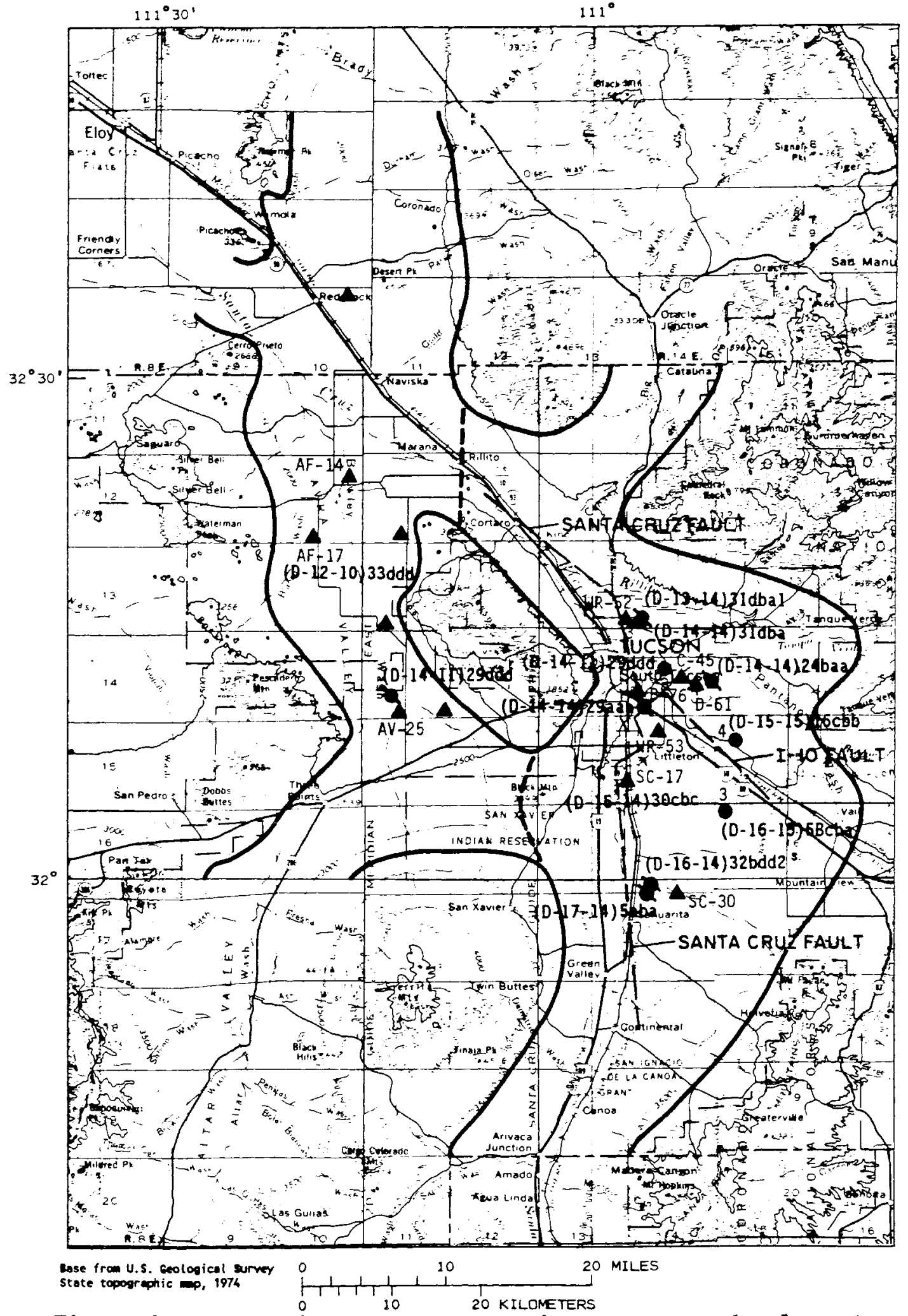

Figure 2.--Vertical extensometers, piezometers, and selected observation wells, Tucson basin and Avra Valley. 
sedimentary rocks (Wilson and others, 1969). Three sedimentary units of Cenozoic age-the Pantano Formation of Oligocene age, the Tinaja beds of Miocene to Pliocene age, and the Fort Lowell Formation of Pleistocene age-compose the alluvial-aquifer system (Davidson, 1973, Allen, 1981, and Anderson, 1987a, 1987b, and 1988). The term, aquifer system, refers to a complex set of variably extensive, faulted, and interbedded aquifers and aquitards that function regionally as a wateryielding unit (Poland and others, 1972). Previous investigations have treated the aquifer system in Tucson basin (Anderson, 1972, Davidson, 1973, and Travers and Mock, 1984) and Avra Valley (Moosburner, 1972, Whallon, 1983, and Travers and Mock, 1984) as a single hydrogeologic unit. Continued withdrawal of ground water has developed perched aquifer zones from hydraulic disconnection and irrigation return flow in some places; however, in other places, vertical-hydraulic gradients are maintained between aquifers across confining and semiconfining beds (Leake and Hanson, 1986, and Cuff and Anderson, 1987). Cuff and Anderson (1987) outlined an area of perched ground water in the north-central part of Avra Valley that is similar to an area in west-central Tucson. Perched aquifers, which are caused by irrigation return flow or artificial recharge, can increase the geostatic stress, and transient vertical gradients can result in seepage stresses. Both conditions can increase the change in effective stress on aquitards. Ground water is replenished by mountain-front recharge in Tucson basin and by underflow in Avra Valley. Additional streamflow infiltration contributes to ground-water recharge along the Santa Cruz River and its tributaries in Tucson basin. The Santa Cruz River and ground-water outflow from Tucson basin enter Avra Valley northwest of 
Rillito. Additional underflow enters Avra Valley from Altar Valley to the south. Ground-water outflow from Avra Valley occurs between the Silverbell Mountains and Picacho Peak and enters Picacho basin in the southern part of the lower Santa Cruz River drainage basin. Natural ground-water flow paths and head distributions have been altered by ground-water withdrawals.

Long-term declines in hydraulic head near extensometers were fairly constant and ranged from $2.0 \mathrm{ft} / \mathrm{yr}$ near well AV-25 to $4.8 \mathrm{ft} / \mathrm{yr}$ near well AF-14 in Avra Valley. Recovery or decrease in ground-water decline rates started in 1979-80 near most sites although municipal and industrial usage remained fairly constant. Recovery is mainly the result of retirement of agricultural water rights, reduced mining withdrawals, increased effluent reuse and reclamation, and increased precipitation and runoff recharge. Seasonal and long-term (years to decades) changes in applied stress caused by changes in head in aquifers surrounding the aquitards have been observed in hydrograph records. Because the extensometer sites are former water-supply wells or test holes with large contributing intervals, head changes represent a combination of water-table and confined-aquifer conditions (fig. 3). Seasonal head changes-less than $30 \mathrm{ft}$-generally are one or more months in duration. Long-term head changes-2 to $5 \mathrm{ft} / \mathrm{yr}$-include sequential periods of decline and recovery. Some isolated peaks on extensometer hydrographs appear as small recovery events superimposed on the long-term hydraulic-head decline. In contrast, hydraulic-head changes that caused compaction in a confined aquifer system near Pixley, California (Helm, 1974) were large-greater than 150 ft-regular seasonal decline and recovery cycles without long-term 


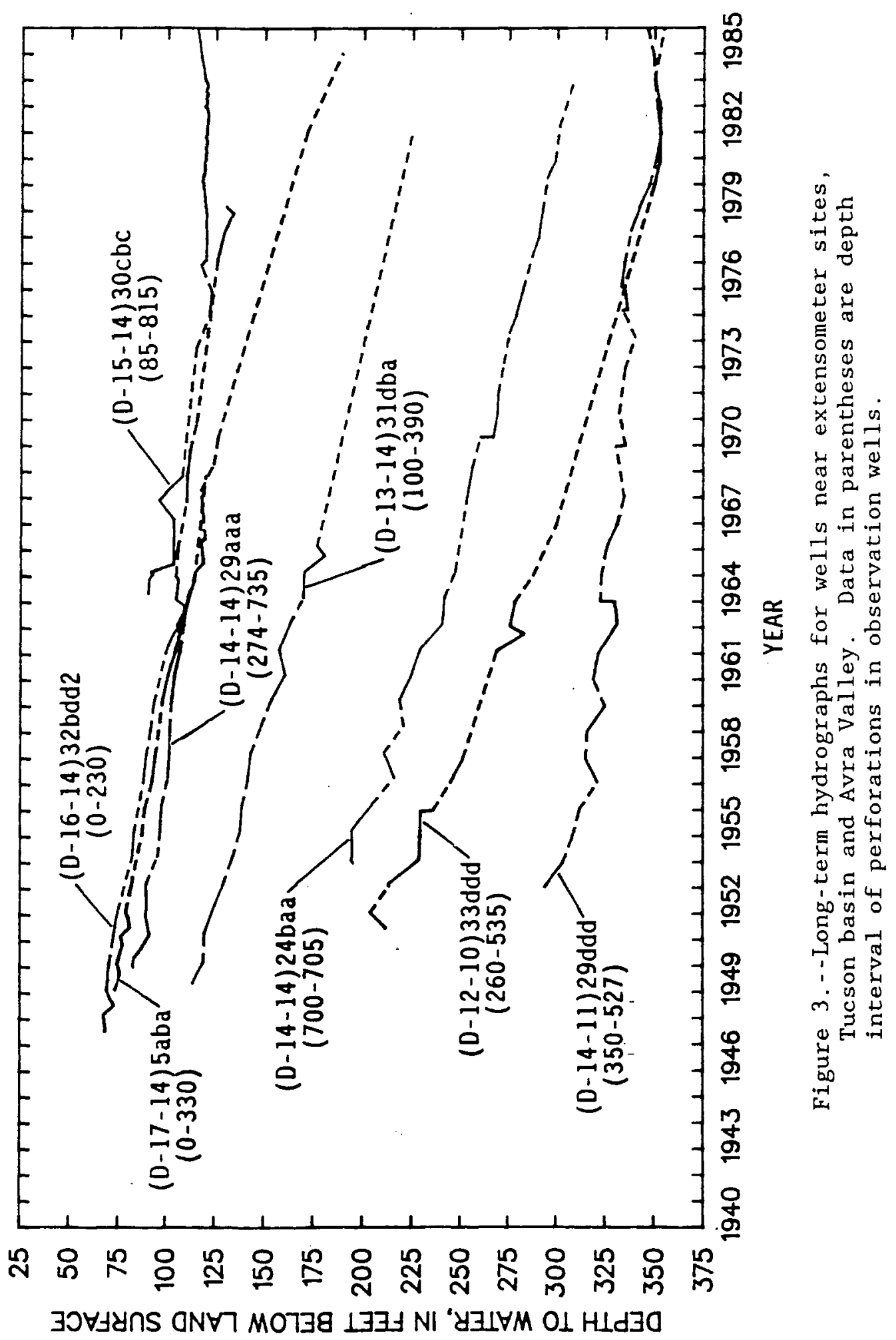


decline in head. Head changes in a confined-and unconfined-aquifer system at an extensometer north of the study area, in Picacho basin, Arizona, are large-greater than $100 \mathrm{ft}$-regular seasonal cycles superimposed on a long-term decline in head-greater than $4 \mathrm{ft} / \mathrm{yr}$. Five groups of piezometers were installed during Davidson's (1973) geohydrologic study of Tucson basin (fig. 4). On the basis of initial water levels of 1966, Davidson (1973, table 1) concluded that hydraulic head generally decreases with depth in coarse-grained sediments of the aquifer system and increases with depth in thick sequences of clay and silt. Coarse-grained sediments, however, also coincide with recharge areas where natural downward hydraulic gradients would be expected. Similarly, parts of the aquifer system composed of clay and silt also coincide with parts of the central-basin graben where natural upward hydraulic gradients would be expected. As of 1966 Davidson found no obvious relation between pumpage and vertical-head distribution.

Data from piezometers near extensometers indicate little or no change in the direction of vertical gradients from 1966 to 1986 in Tucson basin (fig. 4) and from 1981 to 1985 in Avra Valley (Wrege and others, 1985). Spatial distribution of vertical gradients is consistent with distribution of clay and silt (Davidson, 1973, and Anderson, 1987a), hydrochemical facies (Laney, 1973), and recharge and discharge areas of Tucson basin. For example, data from groups A and B show opposing vertical gradients across the I-10 fault in the centralbasin graben in the Tucson basin (figs. 2 and 4). Ground-water declines in piezometers can be larger than ground-water declines in nearby observation wells that are open to larger screened intervals, 

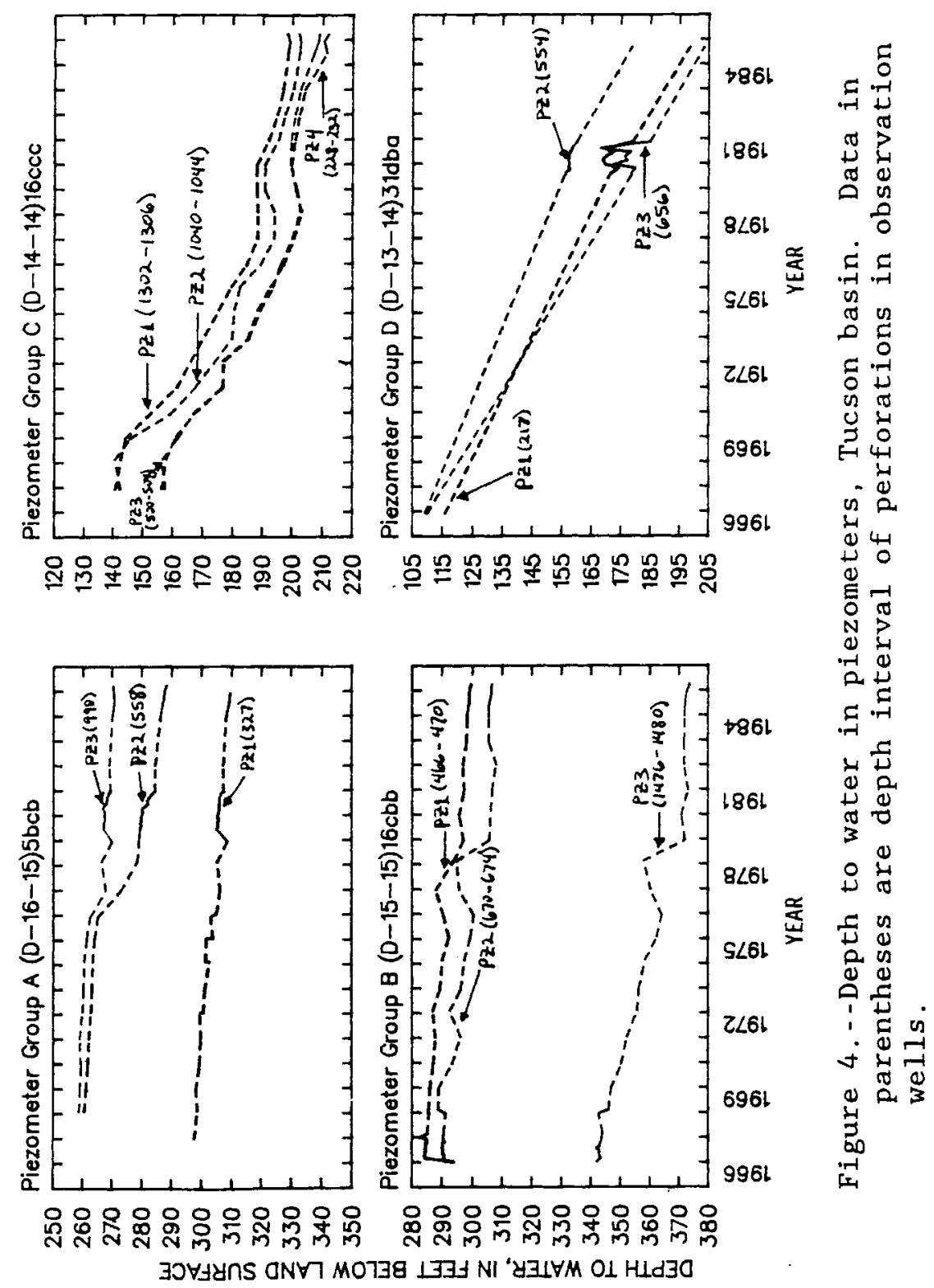
which may represent the integrated decline of several aquifers (fig. 3 , well (D-13-14) 31dba; fig.4, group D). More recent data indicate differential decrease in head in response to ground-water withdrawals at some piezometers in both basins. Increased vertical gradients could contribute to long-term compaction of upper and middle Tinaja beds in some parts of Tucson basin. For this period of study, vertical gradients appear to be fairly constant in both areas.

\subsection{Extensometer-Data Collection}

Vertical extensometers measure vertical compaction between the land surface and a depth at which the extensometer pipe rests on an anchored plate that is set into a sedimentary layer that is less compressible than the monitored sediments (fig. 5). Measured compaction generally is less than measured subsidence because compaction will occur below an extensometer as water levels continue to decline. Extensometers in Tucson basin and Avra Valley were completed to depths of about 800 to $1,000 \mathrm{ft}$ in the less compressible layers of the middle and lower Tinaja beds. Eight extensometers were installed in large-diameter wells that were originally used for water supply or irrigation; two extensometers were installed in 6-inch-diameter test holes. Extensometer construction and instrumentation are illustrated by Babcock and Hix (1982), Babcock and others (1984), and Anderson (1987a, 1988).

Water levels and compaction are measured in the same well at extensometers in the Tucson basin and Avra Valley. All wells are cased with single or multiple intervals of perforations below the water table. Measured water levels represent an integral head over the 


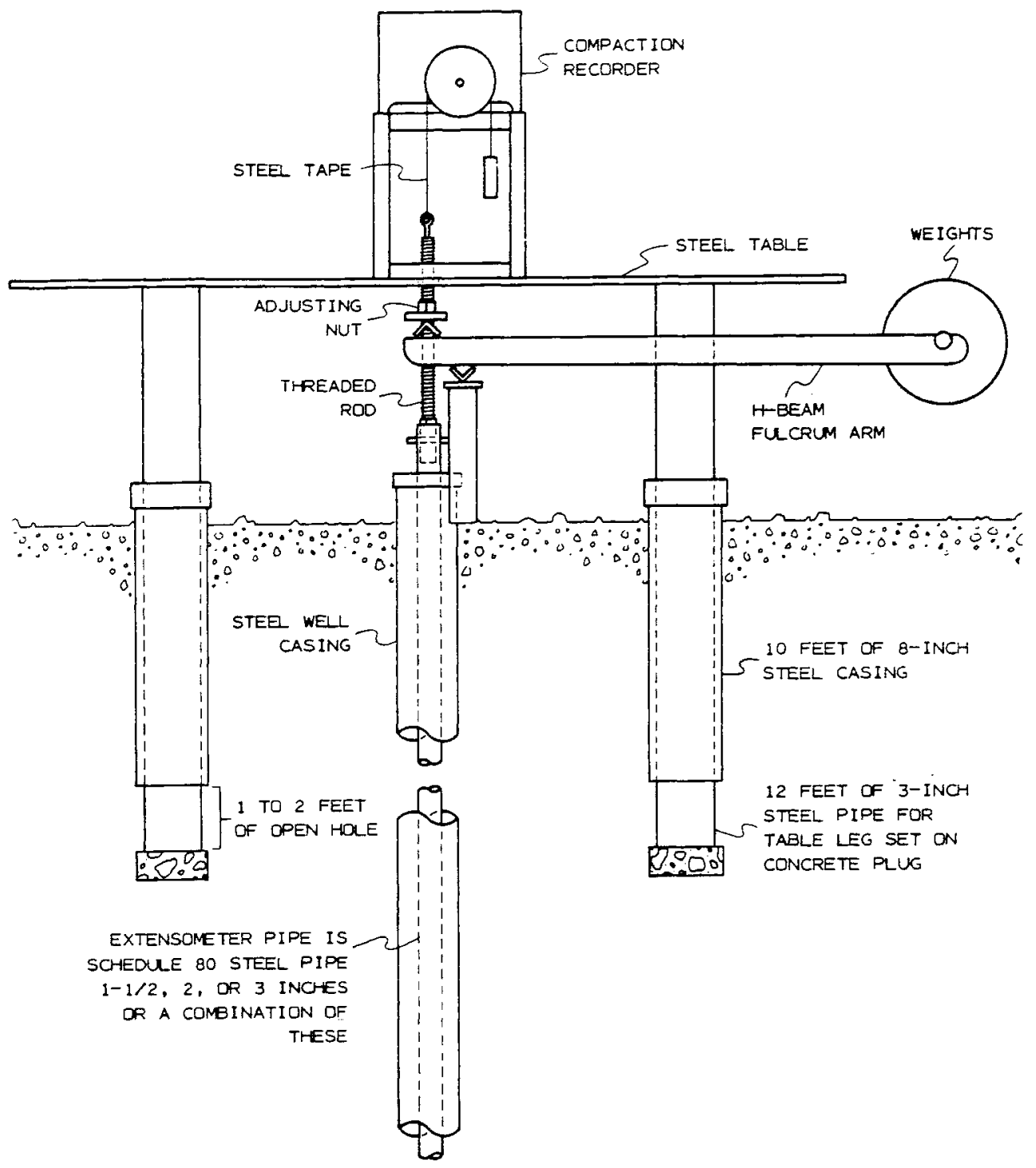

BOTTOM OF EXTENSOMETER PIPE RESTS ON CONCRETE PLUG OR ON CONCRETE-FILLED STEE PIPE DRIVEN TO RESISTANCE.

Figure 5.--Typical vertical-extensometer installation in Tucson basin and Avra Valley. From Anderson (1987a, 1988). 
entire saturated thickness. Chart recorders attached to air-pressure lines are used for monitoring water levels. The recorders are periodically calibrated against steel tapes. Water levels are reported to the nearest $0.1 \mathrm{ft}$. Most chart recorders used to monitor compaction are equipped with a wheel for a 10:1 amplification of movement and yield a resolution of $0.001 \mathrm{ft}$. At selected sites, resolution to the nearest $0.0002 \mathrm{ft}$ was achieved with 50:1 amplification (Anderson, 1987a). The amount and rate of aquifer compaction before installation of the extensometers are unknown; therefore, all net compaction data are referenced to the first day of compaction record. Water-level and compaction data were reduced to single midday values during the period of record.

Compaction data may be adversely affected by frictional, thermal, and bouyant forces as well as stress transmission below the monitored interval. Down-hole friction typically is the limiting factor in determining extensometer accuracy (Riley, 1984). Two kinds of down-hole friction are negative-skin friction and stick-slip friction. Negative-skin friction occurs between sediments and extensometer casing and can cause casing failures. Negative-skin friction tends to redistribute stresses adjacent to the borehole and causes the instrument to under record compaction. Most of the extensometers are wells with multiple reductions in casing diameter that could act as telescoping casing in the event of substantial compaction. Stick-slip friction occurs between the extensometer pipe and the we11 casing and causes near-vertical steps in the data that are approximately the heigth of the stick-slip portion of the total frictional dead band (Riley, 1984). The frictional dead band is about 
$0.0002 \mathrm{ft}$ on the basis of dead-band tests at eight of the extensometers. Total frictional dead band is the difference between the rest point of the instrument arm and the equal manual deflections of the lever arm in opposite directions. Stick-slip friction introduces a small phase lag and clips the peaks at a smaller amplitude of compaction through time. To minimize stick-slip frictional loss, centralizers were installed at several points along extensometer pipes, and counterweights were installed at the surface to balance most of the weight of each pipe. Only the compaction records from wells B-76 and AF-14 show slight stair stepping that is typical of stick-slip friction. We11s $\mathrm{B}-76$ and AF-14 were the only extensometers that also showed a stepped movement of $0.001 \mathrm{ft}$ from seismic waves of the earthquake west of Mexico City on September 19, 1985. The stepped movement indicates that some additional stick-slip friction may not be accounted for by the dead-band tests.

Although friction may be the largest factor in degrading compaction-data accuracy, bouyant and thermal effects may also affect the quality of data in measuring small net compaction. Bouyant forces were minimized through the use of an open-ended extensometer pipe so that water levels would be the same inside and outside the pipe. Seasonal and diurnal thermal effects were minimized by insulating extensometer shelters and anchoring instrument-table legs $12 \mathrm{ft}$ below the land surface. Temperature records from well WR-52 taken adjacent to the table leg and extensometer pipe at a depth of $6 \mathrm{ft}$ indicate a fairly constant difference in temperature between the table and the extensometer pipe. Transient thermal gradients caused by transient intraborehole flow were measured at well WR-52 and may be common at 
other extensometers. We11 B-76 has a bottom-hole temperature of $107^{\circ} \mathrm{F}$ at a depth of $880 \mathrm{ft}$ and has two zones with higher temperatures within the active compaction interval. Well B-76 may also be susceptible to transient thermal effects from nearby pumping wells and cascading water. Small diurnal fluctuations that probably resulted from barometric changes, earth tides, or thermal effects were observed in the records of some extensometers (Anderson, 1987a). For example, compaction data from the extensometer at we11 C-45 shows barometric effects that coincide with large winter storm fronts (Anderson, 1987a). Datums of the cement pad-fulcrum support, instrument table, and extensometer anchor are considered to be stable and to contribute negligible amounts of error through time. Stick-slip friction may affect the record at wells $B-76$ and $A F-14$ by about $0.001 \mathrm{ft}$. Changes in water temperature adjacent to the extensometer pipe may result in changes in length of the pipe, which can result in several thousandths of a foot of error. Stick-slip friction and transient thermal effects are the two factors affecting accuracy of measurements for small net compaction. Maximum resolution for the compaction record from frictional and thermal effects is between 0.001 and $0.003 \mathrm{ft}$ 
CHAPTER 2

\section{COMPONENTS OF AQUIFER-SYSTEM COMPACTION}

In hydrology, inelastic compaction in aquifer systems is synonomyous with primary consolidation (Poland and others, 1972). In this report, compaction is used to describe the decrease in thickness of sediments as a result of an increase in the vertical compressive stress. Compaction is synonomyous with the concept of one-dimensional consolidation used in soil mechanics (Poland and others, 1972). Inelastic compaction occurs when the past maximum effective-stress distribution is exceeded and is proportional to the logarithm of effective stress increase. If the change in effective stress is less than any previous maximum effective stress, compaction is recoverable and is termed elastic compaction (Poland and others, 1972). Although this type of compaction is not necessarily an instantaneous linear response to change in effective stress, it is termed elastic because the compaction is fully recoverable. Total inelastic and elastic compaction lag behind each increase in effective stress because of the impedence to ground-water outflow as the void space is reduced. Subsidence is the total settling of sediments at the land surface. Some subsidence can eventually take place below the depth of an extensometer installation; therefore, subsidence can be larger than measured net compaction. Most extensometers, however, are completed in 
less compressible layers; therefore compaction represents most of the measured land subsidence.

One-dimensional vertical estimates of compaction for aquifer systems are made on the basis of Terzaghi's theory of consolidation using estimates of aquifer-system hydraulic components. Aquifer-system compaction is affected by the preconsolidation stress, hydraulic diffusivity, layering and the stress history of the aquifer system.

\subsection{One-Dimensional Compaction}

Terzaghi (1943) developed the expression for total vertical stress on a horizontal plane at any depth, $z$, in a system at equilibrium as:

$$
P_{t}=P^{\prime}+U
$$

where

$$
\begin{aligned}
& P_{t}=\text { total vertical stress, } \\
& \mathbf{P}^{\prime}=\text { effective stress, and } \\
& \mathbf{U}=\text { pore-water pressure. }
\end{aligned}
$$

Effective stress can be increased by increasing the total vertical stress or by reducing the pore-water pressure.

To develop an expression for the compaction of aquifer systems under field conditions, the following assumptions are made.

(1) The aquifer-system properties are homogeneous.

(2) Drainage occurs at both horizontal boundaries of aquitards.

(3) All flow is within the limits of Darcy's law.

(4) The water and soil grains are incompressible. 
(5) Compression and flow are vertically one dimensional in fine-grained layers.

(6) Compaction is small with vertically averaged hydraulic conductivity, $\mathrm{K}^{\prime} \mathbf{v}$, and specific storage, $\mathrm{S}^{\prime} \mathbf{s}$, remaining constant.

(7) A hysteretic relation exists between change in void ratio, $\Delta e$, and change in effective stress, $\Delta \mathrm{p}^{\prime}$, and implies no secondary consolidation.

Terzaghi's equation is developed in terms of hydraulic head by using hydrologic components and by assuming that sediment volume reduction through vertical compaction is equal to the volume of water expelled. Effective stress is estimated indirectly from the two measureable quantities total stress and pore-water pressure. The vertical component of effective stress under static conditions can be expressed in terms of total (geostatic) stress and pore-water pressure as the difference of the integral terms (fig. 6):

$$
\begin{aligned}
p^{\prime}= & \int_{0}^{Z}{ }_{w} \operatorname{Sn} \gamma_{w} d z+\int_{Z_{w}}^{Z} n \gamma_{w} d z+\int_{0}^{Z}(1-n) G \gamma_{w} d z \text { (geostatic 1oad) } \\
& -\int_{Z_{w} \gamma_{w} d z}^{Z} \quad \text { (pore-water pressure) (2) }
\end{aligned}
$$

where

$$
\begin{aligned}
& \mathbf{z}_{\mathbf{w}}=\text { depth below land surface to the water table, } \\
& \mathbf{S}=\text { degree of saturation above the water table, } \\
& \mathbf{n}=\text { average porosity, } \\
& \gamma_{\mathbf{w}}=\text { specific weight of water }=0.434 \mathrm{lb} \mathrm{in}^{-2} \mathrm{ft}^{-1},
\end{aligned}
$$




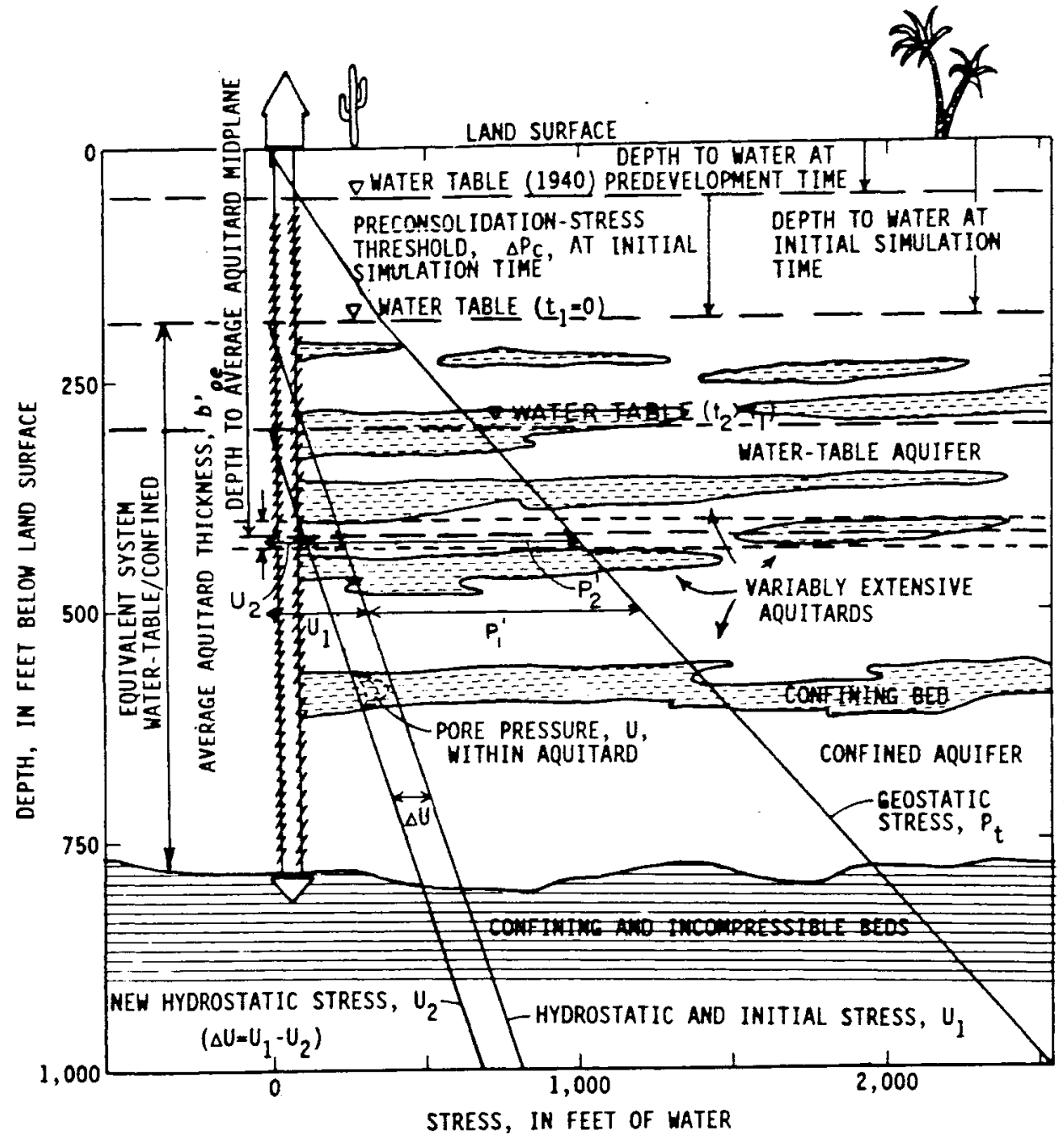

Figure 6.--Generalized stress diagram for aquifer systems with head reduction for equivalent-system simulation of a combined water table and confined aquifer system prior to re-establishment of hydrostatic equilibrium. Modified from Helm (1974, 1975). 
$\mathbf{Z}=$ depth below land surface, and

$G=$ specific gravity of the solids in the aquifer system.

The first three terms represent the components of the geostatic stress within a vertical column and are the weight of the water above the water table, the weight of the water below the water table, and the weight of the sediments. The fourth term is the pore-water pressure or upward bouyant force under static conditions.

In an aquifer system, the change in stress applied to the boundary of an aquitard is measured as a change in head in the aquifers surrounding an aquitard (fig. 6). By continuity, the change in applied stress is equal to the change in effective stress at the aquiferaquitard boundary. Thus, a decrease in pore-water stress in an adjacent aquifer is equal to an increase in effective stress at the boundary of an adjacent aquitard $\left(\Delta \mathbf{p}^{\prime}=-\Delta \mathrm{u}\right)$. The increase in effective stress is dissipated through the expulsion of pore water from within the aquitard in order to bring the aquitard back into equilibrium. This process results in a volume change through a reduction in the void space within the aquitard. Helm (1975) expressed the volume reduction as vertical strain in an aquitard in terms of an average void ratio as

$$
\Delta \mathrm{b}^{\prime} / \mathrm{b}^{\prime}{ }_{0}=-\Delta \mathrm{e} /(1+\mathrm{e})
$$

where

$$
\begin{array}{ll}
\Delta \mathrm{b}^{\prime} & =\text { linear compaction, } \\
\mathrm{b}_{0} & =\text { initial aquitard thickness, } \\
\Delta \mathrm{b}^{\prime} / \mathrm{b}^{\prime} & =\text { mean vertical strain, }
\end{array}
$$




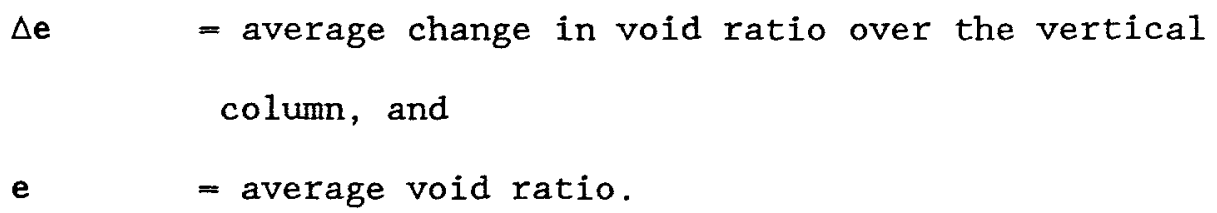

In soil mechanics, the empirical relation between loss of void space and increase in effective stress is defined as $-\Delta e / \Delta \mathrm{p}^{\prime}$ for inelastic compaction and is termed the empirical coefficient of compressibility, $a_{v}$. The inelastic loss of volume from aquitards in an aquifer systems is expressed in terms of the empirical coefficient of compressibility as the skeletal inelastic specific storage (Helm, 1975):

$$
s^{\prime}{ }_{s k v}=\left(a_{v} \gamma_{w}\right) /(1+e)
$$

where

$$
\mathbf{S}_{\mathbf{s k v}}=\text { inelastic specific storage for aquitards. }
$$

By analogy, inelastic specific storage is the slope between compaction and change in effective stress (Helm, 1975):

$$
S^{\prime}{ }_{s k v}=\gamma_{w}\left(\Delta b^{\prime} / b^{\prime}{ }_{0}\right) / \Delta \mathrm{p}^{\prime} \text {. }
$$

The slope that represents a value for average inelastic specific storage for an aquitard is a linear approximation of the more nonlinear behavior of soil compression measured in laboratory tests (fig. 7).

The volume change can also be expressed through continuity of flow across a unit of aquitard. Volume change is the difference between inflow and outflow of the unit volume for a given time interva1. By expressing the change in pore-water pressure in terms of hydraulic head and by using Darcy's law, inflow, $Q_{\text {in }}$, can be expressed as

$$
Q_{\text {in }}=\left(K_{v}^{\prime} / \gamma_{w}\right)\left(\partial u / \partial z+\partial^{2} u / \partial z^{2}\right) d x d y d t
$$




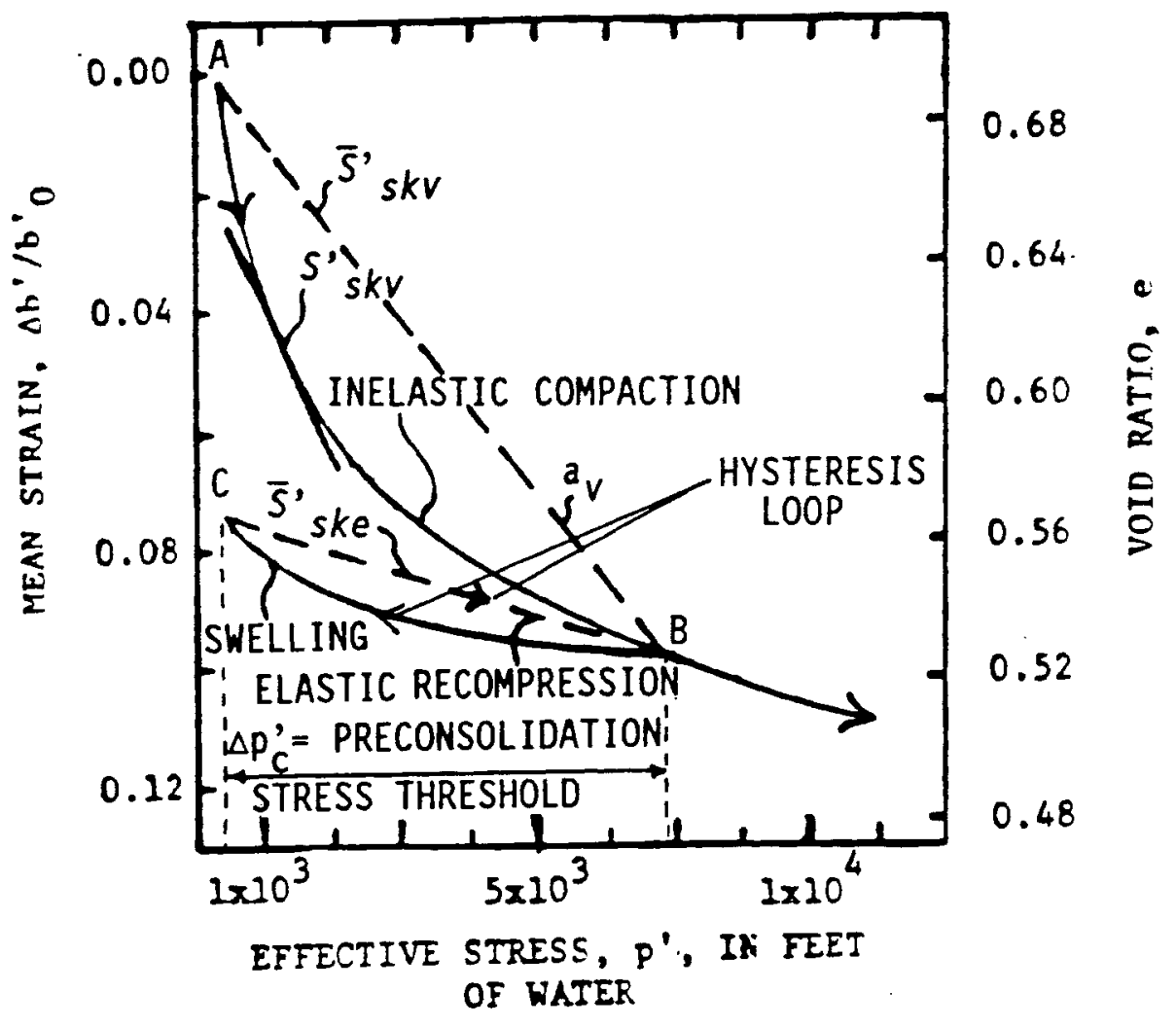

Figure 7.--Idealized stress-mean strain relation on linear coordinates for a saturated volume element of compacting clay. From Helm (1974). 
and outflow, Q out, as

$$
Q_{\text {out }}=\left(K_{v}^{\prime} / \gamma_{w}\right) \partial u / \partial z d x d y d t
$$

Thus, volume change from inflow and outflow in an aquitard column of unit area can be expressed as

$$
Q_{\text {out }}-Q_{\text {in }}=-\left(K_{v}^{\prime} / \gamma_{w}\right) \partial^{2} \mathbf{u} / \partial z^{2} d t
$$

Through continuity of volume of outflow with volume of void reduction, equations 5 and 8 yield Terzaghi's one-dimensional consolidation equation in terms of hydraulic head:

$$
C_{v} \partial^{2} u / \partial z^{2}=\partial u / \partial t
$$

where the properties of the aquitard are contained in the coefficient of consolidation, $\mathrm{C}_{\mathbf{v}}$ :

$$
C_{v}=\left(K_{v}^{\prime} / \gamma_{w}\right)\left[(1+e) / a_{v}\right]=K_{v}^{\prime} / S_{s k v}^{\prime}
$$

where

$$
\mathbf{K}_{\mathbf{v}}^{\prime} / \mathbf{S}_{\mathbf{s k v}}^{\prime}=\text { vertical hydraulic diffusivity. }
$$

The coefficient of consolidation is not a constant and in laboratory consolidation tests is determined for each increase in effective stress. Change in compaction may be expressed in terms of change in logarithm of effective stress (Jorgensen, 1980) as

$$
\Delta b^{\prime \prime}=\left(b^{\prime}{ }_{0} c_{c} /(1+e)\right)\left(\log _{10} p^{\prime}{ }_{2}-\log _{10} p^{\prime}{ }_{1}\right)
$$

where

$$
\begin{aligned}
\Delta \mathbf{b}^{\prime \prime}= & \text { nonlinear compaction, } \\
\mathbf{C}_{\mathbf{c}}= & \text { compression index, } \\
\mathrm{p}_{2}^{\prime}= & \text { effective stress larger than the initial effective } \\
& \text { stress, and }
\end{aligned}
$$




$$
\mathrm{p}_{1}^{\prime} \quad=\text { initial effective stress. }
$$

Jorgensen (1980, equation 50) expresses $C_{c}$ in terms of the slope of the compression line, $a_{v}$, as

$$
c_{c}=-\Delta e / \Delta\left(\log _{10} p^{\prime}\right) \text {. }
$$

From equation 5, the linear approximation of compaction in terms of initial thickness, $\mathbf{b}_{\mathbf{o}}^{\prime}$, becomes

$$
\Delta b^{\prime}=b^{\prime}{ }_{0} s^{\prime}{ }_{s k v} \Delta p^{\prime} / \gamma_{w} .
$$

The inelastic specific storage, $\mathbf{S}^{\prime}$ skv' can now be expressed in terms of the compression index as done for example by Jorgensen (1980, equation 59):

$$
S^{\prime}{ }_{\text {skv }}=0.434 \gamma_{w} c_{c} /\left(p^{\prime}(1+e)\right) \text {. }
$$

Helm (1976) showed that the product of $\mathrm{S}^{\prime}{ }_{\mathrm{skv}}$ and $\mathrm{p}^{\prime}$ for constant $\mathrm{C}_{c}$ is constant for variable $\mathrm{p}^{\prime}$. Thus, the error in compaction estimates from use of a linear estimate can be expressed as

$$
\begin{aligned}
& \text { Error }=\left(\left(\Delta \mathrm{b}^{\prime}-\Delta \mathrm{b}^{\prime}\right) / \Delta \mathrm{b}^{\prime \prime}\right) \times 100
\end{aligned}
$$

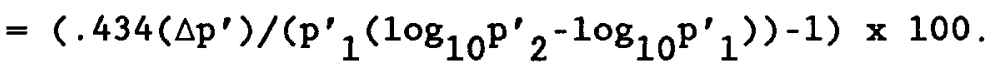

The percent error in using the linear form of the compaction estimate is determined empirically to be just less than half the percentage increase in effective stress. If changes in effective stress represent a small percentage of the initial effective stress, the linear approximation of specific storage yields an acceptable approximation of compaction. 
Helm (1976) also shows that vertical hydraulic conductivity decreases with an increase in effective stress:

$$
\mathrm{K}_{v^{\prime} / \mathrm{K}_{\mathrm{O}}^{\prime}}^{\prime}=\left(\mathrm{P}_{\mathrm{o}}^{\prime} \max / \mathrm{P}^{\prime} \max \right)^{\mathrm{m}}
$$

where

$$
\begin{aligned}
& \mathrm{K}_{\mathrm{vo}}^{\prime} \quad=\text { initial vertical hydraulic conductivity, } \\
& \mathrm{P}_{0}^{\prime} \max =\text { initial effective stress, and } \\
& \text { m } \quad=C_{c} / C_{k} \text {, which is a ratio of empirical coefficients } \\
& \text { that typically ranges from } 0.5 \text { to } 2.0 \text { and where } \\
& c_{k}=\Delta \log \left(k_{v}^{\prime}\right) / \Delta e \text {. }
\end{aligned}
$$

A value of 1 for $m$ is equal to setting the coefficient of consolidation to a constant value. For a value of 2 for $\mathrm{m}$ and a 10-percent change in effective stress, the decrease in vertical hydraulic conductivity is about 20 percent. Because both hydraulic conductivity and specific storage are reduced with an increase in effective stress, the ratio of the two hydraulic properties generally remains constant during small ranges in effective stress. The use of constant hydraulic diffusivity for changes in effective stress of less than 10 percent that result in compaction of less than $0.1 \mathrm{ft}$, therefore, is considered reasonable for simulations of historical compaction data presented in this report.

\subsection{Preconsolidation Stress}

Terzaghi's (1943) one-dimensional consolidation equation is

for small inelastic compaction. In an aquifer system, the stress level for the transition between predominantly elastic and inelastic compaction is defined as the preconsolidation stress, $\mathrm{p}_{\mathrm{c}}^{\prime}$ (Holzer, 
1981). The preconsolidation-stress threshold, $\Delta \mathbf{p}_{\mathrm{c}}{ }^{\prime}$, (fig. 7, between points $C$ and B) is the amount of increase in effective stress required to reach the previous maximum preconsolidation stress in the aquifer system before withdrawal of ground water (Holzer, 1981) and is related to overconsolidation, diagenesis, and nonhydrodynamic compaction. Overconsolidation is a prestressing of the aquifer system to pressures larger than the current effective-stress distribution and may vary areally or by formation. During periods of sustained overdrafts and large seasonal drawdowns of the ground-water system, exceedance of the preconsolidation-stress thresholds generally is induced by man's activities (Riley, 1969).

Preconsolidation stress can be estimated from laboratory-consolidation tests on undisturbed core samples from various parts of the aquifer system or from historical water-level decline and land-subsidence records. Holzer (1981) indicates that core samples range from underconsolidated to overconsolidated material and show some increase in preconsolidation stress with depth except in regions where large, shallow ground-water withdrawals have disrupted the natural distribution of stress. The ratio of land subsidence to water-level decline typically changes at a point in time when compaction of the aquifer system or dominant layers within the system changes to inelastic compaction. The amount of water-level decline from predevelopment to threshold conditions is equivalent to the preconsolidation-stress threshold of the aquifer system (Holzer, 1981). For example, vertical profiles across the regional-aquifer system of water-level decline and land subsidence spatially show this transition 
from elastic to inelastic compaction for a specified time period. Profiles shown in Anderson (1987a, 1988) for Tucson basin and Avra Valley are consistent with the 52- to 207-foot range of water-level declines for other subsidence areas (Holzer, 1981).

\section{$\underline{2.3 \text { Components of Storage }}$}

In a homogenous aquitard within the aquifer system, the time required to dissipate excess pore pressure depends on both the volume of water being forced from the aquitard, which results in a vertical shortening and volume reduction of sediments, and the resistance to outflow $\left(1 / \mathrm{K}^{\prime}{ }_{\mathrm{v}}\right)$ of the excess water. When net-compaction measurements represent a composite of aquitard compactions within an aquifer system, net compaction can be affected by different aquitards and by different magnitudes and rates of stress. For example, after a short pumping season, a large range in maximum excess pore pressures can develop within an aquifer system. The thinner or more permeable aquitards will contain the least excess pore pressure and will return to elastic conditions soon after the onset of water-level recovery, whereas the thicker or less permeable aquitards will continue compacting at slower rates that probably extend past the period of water-level recovery. When a drop in water level causes an increase in applied stress, the product of the volume change with the resistance to outflow represents the time constant (Riley, 1969):

$$
\tau=\left[\mathrm{S}_{\mathrm{S}}^{\prime}\left(\mathrm{b}^{\prime}{ }_{\mathrm{o}} / 2\right)^{2}\right] / \mathrm{K}_{\mathrm{v}}^{\prime}
$$

where

$$
\tau=\text { time constant and }
$$




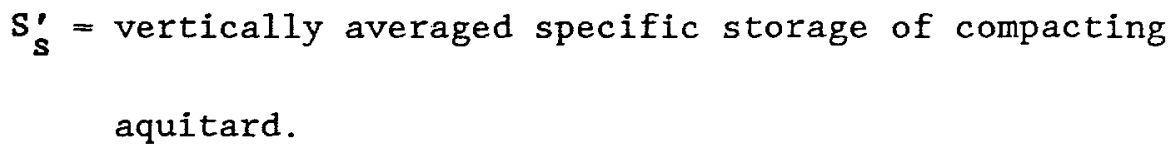

The time constant represents the time required to dissipate 93 percent of the excess pore-water pressure and is derived from solution of Terzaghi's equation (Holtz and Kovacs, 1981). Thus, the percentage of total compaction occurring after an increase in applied stress is the elapsed time divided by the time constant. Net compaction at any elapsed time is the product of the degree of compaction and the total compaction that will occur from the increase in applied stress. Helm (1974) suggested that both aquifer and aquitard material have some degree of delayed response for elastic and inelastic compaction. Helm makes the further distinction between seasonal and short-term stress changes that can occur above the past maximum effective stress and that can result in cycles of elastic compaction. Aquifer tests used to estimate elastic storage are frequently derived from short-term stress changes. Storage values derived from aquifer tests generally are less than storage values of longer, seasonal cycles of elastic compaction. Riley (1969) developed a graphical method to estimate aquifer-system elastic and inelastic storage coefficients from stressstrain or stress-compaction diagrams. Extensometer data can be used to estimate graphically aquifer-system elastic storage components from seasonal and short-term stress changes. The aquifer-system elastic storage coefficient is the slope of the recovery limb of the hysteresis loops (fig. 7, between points $B$ and $C$ ), and can be expressed as

$$
\mathrm{s}_{\mathrm{ke}}^{*}=-\gamma_{\mathrm{w}} \Delta \mathrm{b} / \Delta \mathrm{p}^{\prime}
$$

where 
$s_{k e}^{*}=$ aquifer-system skeletal elastic storage coefficient, $\Delta \mathrm{b}=$ measured recoverable compaction, and $\Delta \mathrm{p}^{\prime}=$ change in effective stress due to seasonal or short-term drawdown.

These loops are analogous to the loops of elastic compaction (fig. 6, from point $C$ to $B$ ) that occur in aquifer systems at stresses less than the past maximum effective stress (fig. 6, point B).

The skeletal components of aquitard storage needed for compaction simulations, in turn, can be estimated from graphical estimates of aquifer-system storage and were used to determine the initial components of compressibility for calibration of compaction simulations for extensometer data from the San Joaquin Valley, California (Ireland and others, 1982, table 4). Helm (1974, p. 64) cautions that the validity of this approach depends on the assumption that aquifer-storage coefficients from aquifer tests represent aquifer-storage coefficients from seasonal changes in stress. The sequence of calculations used to estimate elastic-storage components starts with an estimate of the aquifer-storage coefficient, s, and proceeds as follows:

(a) aquifer specific storage,

$$
s_{s}=s / b \text {, }
$$

(b) aquifer skeletal specific storage,

$$
s_{\text {ske }}=s_{s}-s_{s w},
$$

(c) aquifer skeletal storage coefficient,

$$
s_{k e}=s_{s k e} b \text {, }
$$

(d) aquitard skeletal storage coefficient, 


$$
s_{k e}^{\prime}=s_{k e}^{*}-s_{k e}
$$

(e) aquitard skeletal specific storage,

$$
\mathrm{S}^{\prime}{ }_{\text {ske }}=\mathrm{s}^{\prime}{ }_{\mathrm{ke}} / \mathrm{b}^{\prime},
$$

(f) aquitard specific storage,

$$
S^{\prime}{ }_{s}=s^{\prime}{ }_{s k e}+s_{s w}
$$

(g) aquitard storage coefficient,

$$
S^{\prime}=S^{\prime}{ }_{S} b^{\prime},
$$

(h) aquifer-system storage coefficient,

$$
s^{*}=s+s^{\prime} \text {, }
$$

with

$$
\begin{aligned}
& b^{\prime}=\text { aggregate thickness of aquitards, } \\
& b=\text { aggregate thickness of aquifers, and }
\end{aligned}
$$

where

$$
\mathrm{s}_{\mathbf{s w}}=\mathrm{n} \beta_{\mathrm{w}} \gamma_{\mathrm{w}}
$$

with

$$
\begin{aligned}
& \beta_{\mathrm{w}}=\text { compressibilty of water, which is } 3.3 \times 10^{-6} \mathrm{in}^{2} 1 \mathrm{~b}^{-1}, \\
& \quad \text { and } \\
& \mathrm{n}=\text { porosity. }
\end{aligned}
$$

Initial estimates of aquitard elastic specific storage (equation 19e) are used in the calibration of the compaction simulations. With longterm aquifer tests generally unavailable, this method also provides an additional technique for estimating aquifer-system storage coefficients for problems involving long-term cyclic stresses (equation 19h). An approximation of the aquifer-system inelastic storage coefficient is the linear slope of a line at or near the equilibrium 
points (fig. 7, points A and B) of sequential hysteresis loops and parallel to the slope of inelastic compaction between loops (Riley, 1969, fig. 1). Inelastic compaction of aquifers and the compressibility of water are considered negligible in relation to inelastic aquitard compaction. Inelastic compaction however may be affected by the relative proportions of aggregate thickness of aquifers and aquitards that represent the aquifer system at any extensometer site. Thus, inelastic storage coefficient for the aquifer system can be used in most cases beyond the preconsolidation stress to directly approximate aquitard inelastic specific storage as

$$
\mathrm{s}^{\prime}{ }_{\mathrm{skv}}=\mathrm{s}_{\mathrm{kv}}^{*} / \mathrm{b}^{\prime},
$$

where

$$
\mathrm{s}_{\mathrm{kv}}^{*}=\text { inelastic specific storage of aquifer system. }
$$

\subsection{Geometric Properties}

The geometric properties that were used to define the flow medium at each extensometer site included layer frequency, composite average percent clay and silt, and equivalent (weighted-average) thickness. These three indices collectively give a measure that is distinctive for the three major depositional environments in these two alluvial basins-playa deposits, coallescing alluvial-fan deposits, and a zone of interfingering between playas and alluvial fans (Anderson and Hanson, 1987). Layering is the sequence of coarse- and fine-grained beds penetrated by each extensometer well. A compilation of layering yields a better understanding of the varying stress-strain responses measured at extensometers. Layering frequency provides a basis of 
comparison of sediments penetrated by extensometer wells that is independent of total depth or depositional environment. An interpretation of layering is also required to compute the equivalentaquitard thickness (Helm, 1975) that can be used as an option for compaction modeling. Interpretation of layering at extensometers was based on particle-size data, inspection of well cuttings, geophysical logs, and stratigraphic studies by Anderson (1987a, 1987b, 1988). Composite-average percent clay and silt is the weighted-average thickness of clay and silt that was estimated from sieve analysis of regular depth-interval samples of drill cuttings from the Fort Lowell Formation and the upper Tinaja beds. The composite-average percentage of clay and silt was used by Anderson (1987a, 1988, figs. 4, 5) to delineate sediment facies in the Fort Lowell Formation and upper Tinaja beds and to make initial predictions of potential land subsidence.

The equivalent thickness is a geometric weighted average of aquitard thicknesses expressed by Helm (1974, p. 120) as

$$
b^{\prime}{ }_{o e}=2\left(\left[\sum_{1=1}^{N}\left(b^{\prime}{ }_{o i} / 2\right)^{2}\right] / N\right)^{1 / 2} \text {, }
$$

where

$$
\begin{aligned}
& { }^{\mathbf{b}}{ }_{\text {oe }}=\text { initial equivalent thickness of an idealized } \\
& \text { aquitard, } \\
& \mathbf{b}_{\text {oi }}=\text { initial thickness of an individual aquitard within } \\
& \text { the aquifer system, and } \\
& \mathbf{N}=\text { total number of aquitards within the aquifer system. }
\end{aligned}
$$

The weighted average takes a form similar to the thickness term in the time factor, $\tau$, (equation 17) extracted from Terzaghi's (1943) analytical solution. Although no formal derivation exists, using the 
mean of the squared half-thickness of all the aquitards in the aquifer system preserves the rate of compaction for the equivalent number of aquitards (Helm, 1974, p. 120). Both the rate of compaction and ultimate compaction are preserved because the cumulative sum of equivalent aquitard thicknesses is initially set equal to the actual aggregate aquitard thickness.

Additional estimated properties that are required for simulation of aquifer-system compaction include hydraulic conductivity, porosity, specific yield, specific retention, and specific gravity of the sediments. Horizontal hydraulic conductivities were transformed into equivalent vertical hydraulic conductivities that represent the layered aquifer system (Freeze and Cherry, 1979) on the basis of a common anisotropy ratio- $\mathrm{K}_{\mathrm{h}} / \mathrm{K}_{\mathrm{v}}=100,000 / 1$. This order-of-magnitude anisotropy value was determined from selected wells in Avra Valley (D.R. Pool, hydrologist, U.S. Geological Survey, written commun., 1985). If aquifer-test data were unavailable, horizontal-hydraulic conductivities were estimated through grain-size relations developed for Tucson basin (T.W. Anderson, hydrologist, U.S. Geological Survey, written commun., 1985) and reduced by the same anisotropy ratio.

Single estimates of porosity, specific yield, specific retention, and specific gravity of the sediments were applied to all sites. An average porosity of 25 percent was estimated from borehole-gravity data (Tucci and others, 1982, Tucci and Pool, 1986) for a grain density of $2.65 \mathrm{~g} / \mathrm{cm}^{3}$. Specific-yield estimates from transient-model simulations range from 0.09 to 0.15 (Anderson, 1972, Moosburner, 1972, D. R. Pool, written commun., 1985) with a typical 
value of 0.12 (Freethey, 1986). The specific retention of 0.13 was estimated as the difference between porosity and specific yield. 
CHAPTER 3

\section{AQUIFER-SYSTEM COMPACTION}

As of 1986, maximum measured subsidence in Tucson basin was $0.5 \mathrm{ft}$ (Strange, 1983, Anderson, 1987a). Anderson (1987a, fig. 7) shows subsidence and water-level decline along three profiles in Tucson basin. Land subsidence from less than 0.1 to as much as $0.5 \mathrm{ft}$ was measured between land surveys in 1951-54 and 1979-80. The largest amount of subsidence in Tucson basin occurred south of Davis-Monthan Air Force Base (Winikka, 1984; Anderson, 1987a, fig. 7). Anderson (1987a) states that average subsidence rate south of Davis-Monthan Air Force Base was about $0.05 \mathrm{ft} / \mathrm{yr}$ from 1976 to 1980 and the general increase in subsidence was related to water-level decline in the same period. The long-term ratio of subsidence to water-level decline is about $0.003 \mathrm{ft} / \mathrm{ft}$ compared to $0.02 \mathrm{ft} / \mathrm{ft}$ in 1979-80 (Anderson, 1987a). The accelerating rate of subsidence and the large specific-unit compaction $^{1}$ value at extensometer SC-17 suggest that parts of the

${ }^{1}$ Specific-unit compaction is the gross compressibility of the system, and is defined as the compaction of the deposits, per unit thickness, per unit increase in applied stress, during a specified time period (Poland and others, 1972). 
alluvial aquifer may be in transition from predominantly elastic to inelastic compaction (Anderson, 1987a). The water-level decline that represents the initial preconsolidation-stress threshold of 1979-82 may be about $150 \mathrm{ft}$ in the northern part of Tucson basin and $50 \mathrm{ft}$ in the southern part (Anderson 1987a, fig. 7). For the purpose of this study, the present active interval of compaction coincides with the Fort Lowel1 Formation and the upper Tinaja beds but may include parts of lower units in some areas (Anderson, 1987a and 1988).

Anderson (1988, fig. 7) shows subsidence and water-level

declines in Avra Valley between 1948-52 and 1980 along one northwest-trending profile that bisects the northern part of Avra Valley. A maximum of $1.1 \mathrm{ft}$ of land subsidence and a long-term ratio of subsidence to water-level decline of about $0.01 \mathrm{ft} / \mathrm{ft}$ are indicated by data for the area southeast of Picacho Peak (Anderson, 1988, fig. 7). The water-level decline that represents the initial preconsolidation-stress threshold may be between 100 and $120 \mathrm{ft}$ in the northern part of Avra Valley (Anderson, 1988, fig. 7). As in Tucson basin, the active interval of compaction is assumed to coincide generally with units equivalent to the Fort Lowell Formation and upper Tinaja beds (Anderson, 1988).

\subsection{Extensometers in Tucson Basin}

As of 1986, more than 6 years of aquifer-system compaction data are available for wells SC-30, SC-17, B-76, C-45, and D-61 and more than 3.5 years for well WR-52 in Tucson basin (fig. 2). Test hole WR-53, which has less than 3 years of data, had no compaction. Components of storage that were estimated from field data and used as 
initial parameter estimates for compaction simulations are summarized in table 1 .

Records for well SC-30 in the southern part of Tucson basin northeast of Sahuarita (fig. 2) show seasonal changes in stress with seasonal water-level recoveries and aquitard expansion in winter months (fig. 8). Well SC-30 completely penetrates the Fort Lowe11 Formation and upper Tinaja beds and partially penetrates the middle Tinaja beds (fig. 9). The graph of stress and compaction for well SC-30 (fig. 10) shows large hysteresis loops that correspond to the seasonal water-level fluctuations.

Wel1 SC-17 is north of well SC-30, east of Black Mountain and the Santa Cruz River (fig. 2), and less than $0.5 \mathrm{mi}$ east of the Santa Cruz fault in an area where the aquifer sediments generally are clay and silt in the southern central-basin graben. We11 SC-17 is in the Santa Cruz well field that has been in operation since the mid$1940^{\prime} \mathrm{s}$. Seasonal water-level changes of less than $4 \mathrm{ft}$ for the period of record correlate with sustained discharge on the Santa Cruz River, and compaction is comparable to the net compaction of $0.07 \mathrm{ft}$ at well SC-30 (fig. 11). Well SC-17 completely penetrates the Fort Lowell Formation and upper Tinaja beds and partially penetrates the middle Tinaja beds (fig. 12). The stress versus compaction graph for well SC17 (fig. 13) shows two different scales of hysteresis loops that are related to the various recovery events shown in the hydrograph (fig. 10) and may be an indication of response from aquitards under different hydrologic conditions.

Extensometers are at wells B-76, C-45, and D-61 in southern metropolitan Tucson (fig. 2). Well B-76 is adjacent to the trace of 
Table 1.--Summary of aquifer-system storage components and related time constants for selected extensometer sites, Tucson basin and Avra Valley.

\begin{tabular}{|c|c|c|c|c|c|c|}
\hline \multirow{2}{*}{$\begin{array}{l}\text { Aquifer-system } \\
\text { components }\end{array}$} & \multicolumn{4}{|c|}{ Tucson basin } & \multicolumn{2}{|c|}{ Avra Valley } \\
\hline & $\mathrm{SC}-30$ & $\mathrm{sC}-17$ & $B-76$ & $4 R-52$ & $A F-14$ & $A V-25$ \\
\hline \multicolumn{7}{|c|}{ Monitored thickness of compacting sediments } \\
\hline $\begin{array}{l}\text { Aggregate aquifer } \\
\text { Ib, in feet }{ }^{2} \ldots \ldots \ldots \\
\text { Aggregate aquitard }\end{array}$ & 235. & 318. & 187 & 293. & 150. & 396. \\
\hline $\begin{array}{l}\Sigma \mathbf{b}^{\prime} \text {, in feet }{ }^{2} . \ldots \ldots \ldots \\
\text { Total monitored }\end{array}$ & 315. & 324 . & 306. & 274. & 463. & 18. \\
\hline $\begin{array}{l}\mathbf{b}^{*} \text {, in feet }{ }^{2} \ldots \ldots \ldots \\
\text { Total net compaction. }\end{array}$ & 550. & 642. & 493 & 567. & 613. & 414. \\
\hline in feet.............. & .073 & .072 & .051 & .031 & .020 & .008 \\
\hline
\end{tabular}

Elastic storage of compacting aquifer system component due to skeletal compressibility

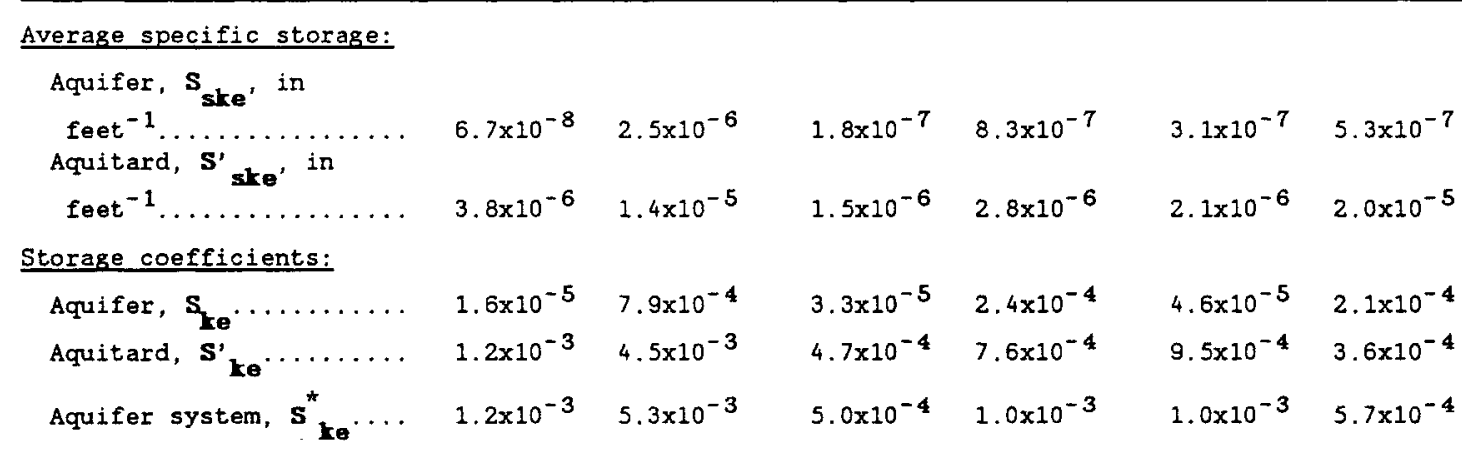

Average specific storage:

\begin{tabular}{|c|c|c|c|c|c|c|}
\hline feet $^{-1} \ldots \ldots \ldots \ldots \ldots$ & 4. $2 \times 10^{-7}$ & $2.8 \times 10^{-6}$ & $5.4 \times 10^{-7}$ & $1.2 \times 10^{-6}$ & $6.6 \times 10^{-7}$ & $8.8 \times 10^{-7}$ \\
\hline feet $^{-1}$. & $4.1 \times 10^{-6}$ & $1.4 \times 10^{-5}$ & $1.9 \times 10^{-6}$ & $3.1 \times 10^{-6}$ & $2.4 \times 10^{-6}$ & $2.0 \times 10^{-5}$ \\
\hline 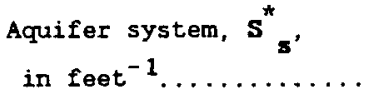 & $2.5 \times 10^{-6}$ & $8.6 \times 10^{-6}$ & $2.0 \times 10^{-6}$ & $2.1 \times 10^{-6}$ & $2.0 \times 10^{-6}$ & $1.7 \times 10^{-6}$ \\
\hline $\begin{array}{l}\text { Aquifer, } \mathbf{s}^{3} \ldots \\
\text { Aquitard, }\end{array}$ & $\begin{array}{l}1 \times 10^{-4} \\
1.3 \times 10^{-3}\end{array}$ & $\begin{array}{l}9 \times 10^{-4} \\
4.6 \times 10^{-3}\end{array}$ & $\begin{array}{l}1 \times 10^{-4} \\
5.8 \times 10^{-4}\end{array}$ & $\begin{array}{l}3.5 \times 10^{-4} \\
8.6 \times 10^{-4}\end{array}$ & $\begin{array}{l}1 \times 10^{-4} \\
1.1 \times 10^{-3}\end{array}$ & $\begin{array}{l}3.5 \times 10^{-4} \\
3.7 \times 10^{-4}\end{array}$ \\
\hline Aquifer system, $\mathbf{s}^{*}$. & $1.4 \times 10^{-3}$ & $5.5 \times 10^{-3}$ & $6.7 \times 10^{-4}$ & $1.2 \times 10^{-3}$ & $1.2 \times 10^{-3}$ & $7.2 \times 10^{-4}$ \\
\hline
\end{tabular}


Table 1.-- Continued.

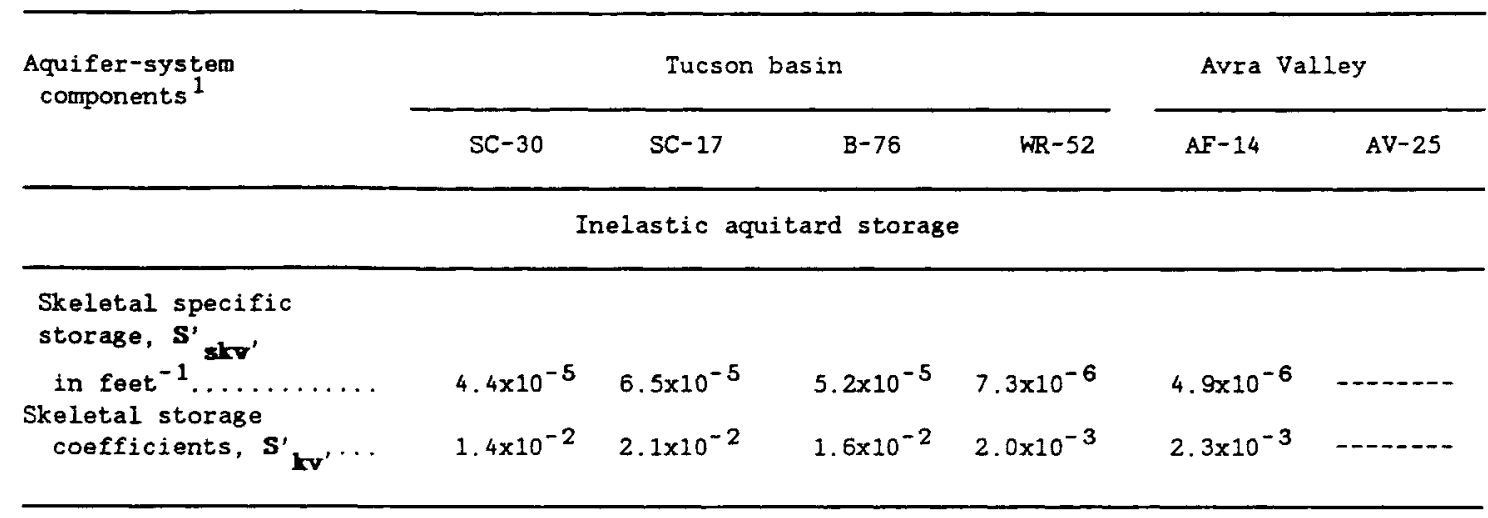

Ratio of inelastic to elastic specific storage for the aggregate of aquitards

\begin{tabular}{|c|c|c|c|c|c|c|}
\hline S'skv/S's $\ldots \ldots \ldots \ldots \ldots$ & 11 & 4.6 & 27 & 2.4 & 4.6 & 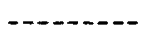 \\
\hline
\end{tabular}

Vertical hydraulic conductivity for the aquitards, in feet per year

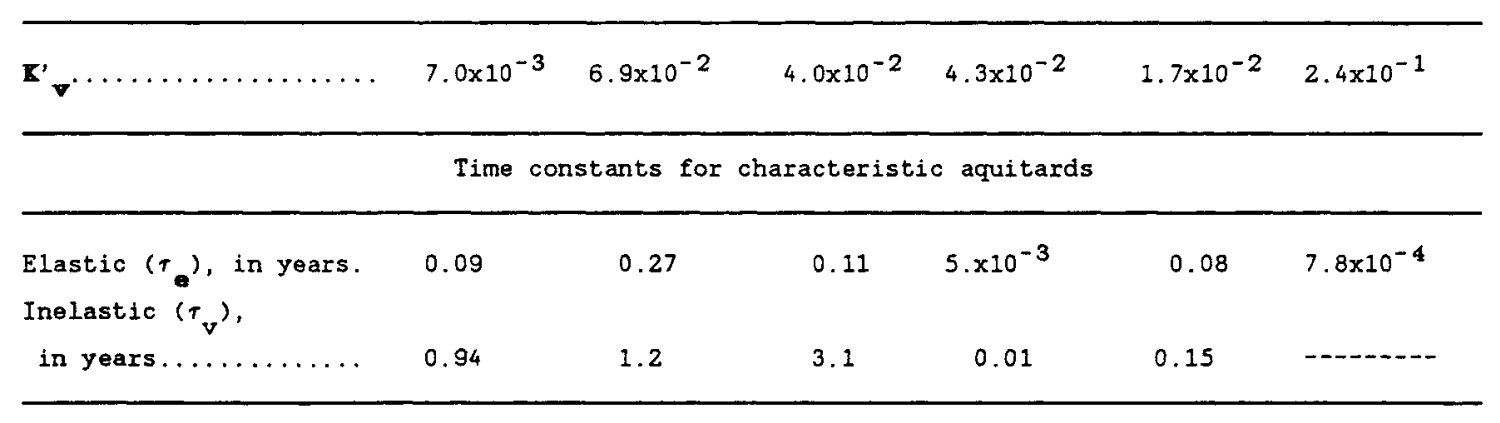

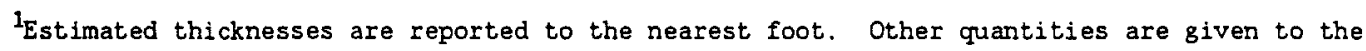
nearest two significant figures. The accuracy of the numbers are not related to the precision shown:

${ }^{2}$ value reported is within the period-of-record initial saturated thickness minus the thickness of less compressible layers and anchor zone.

3 alues of aquifer storage coefficient are assumed values except for wells SC-17 and WR-52. 


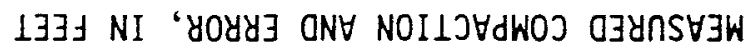

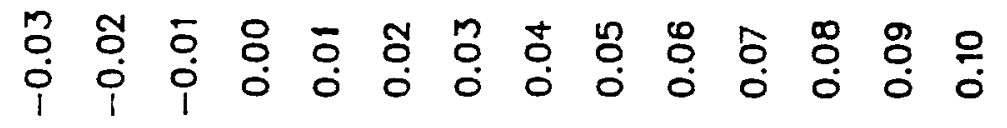

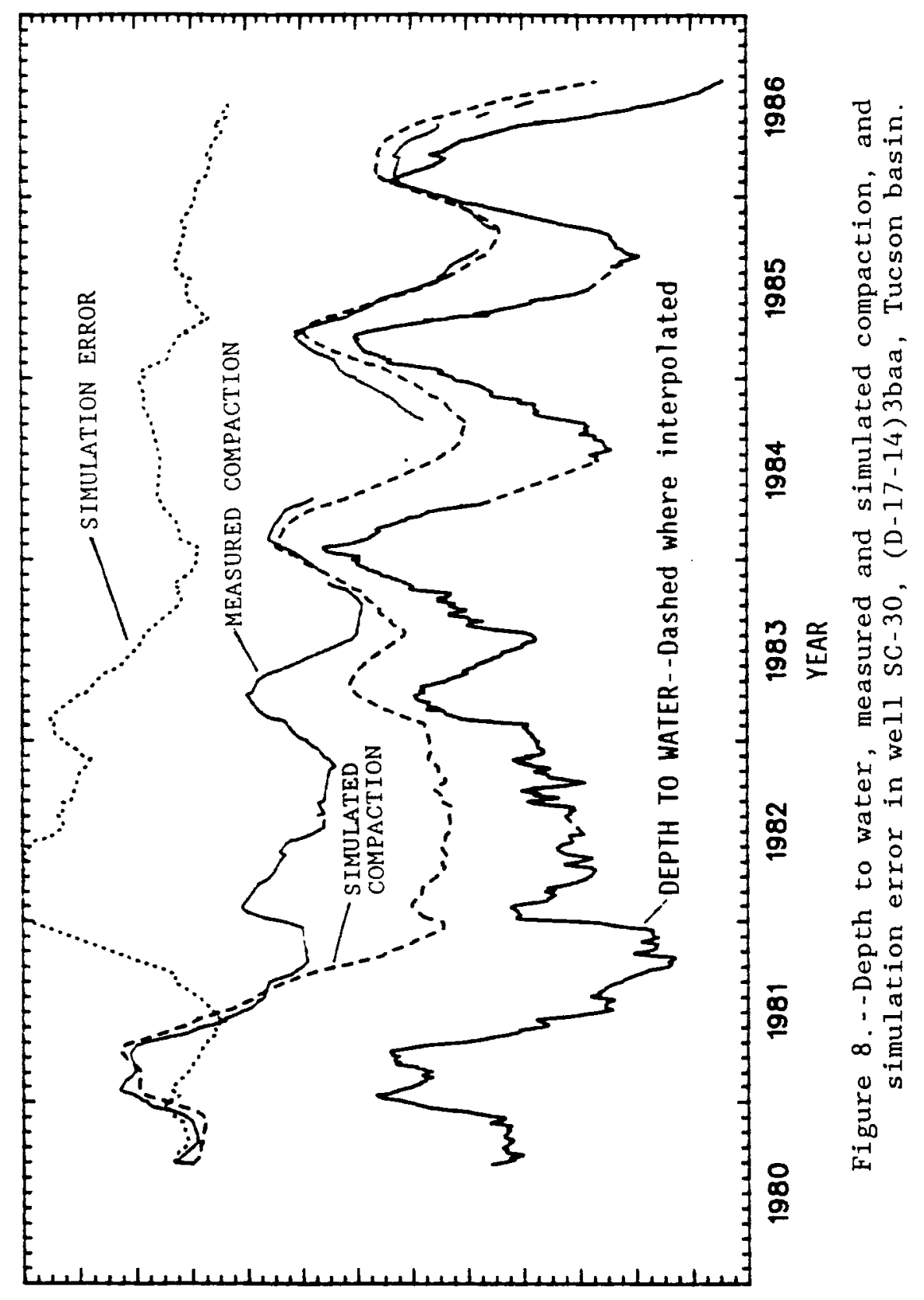

ஜ

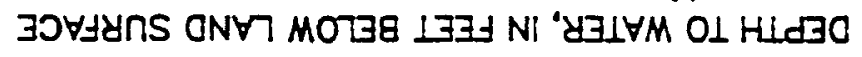




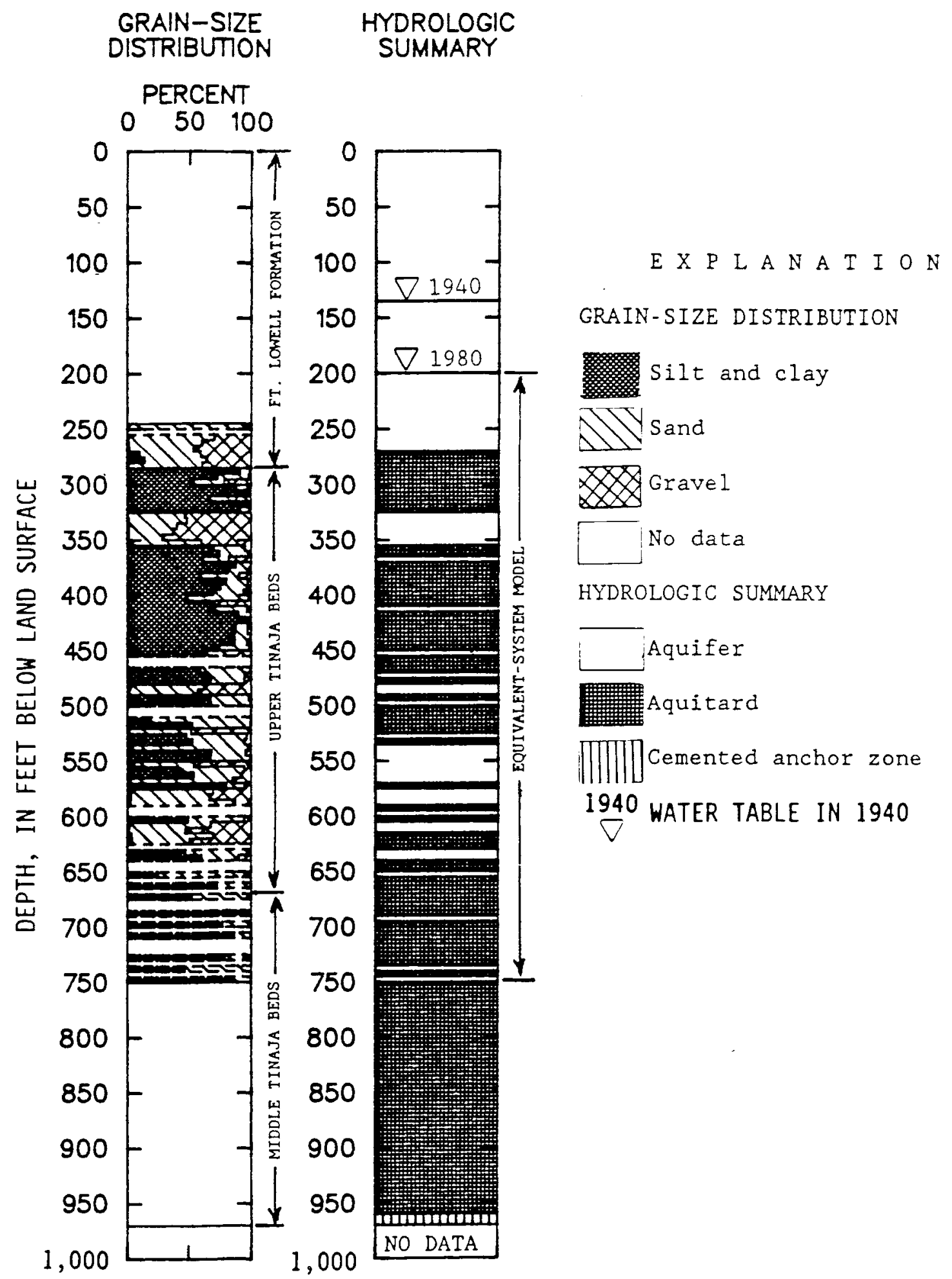

Figure 9.--Grain-size distribution and hydrologic summary for well SC-30,(D-17-14)3baa, Tucson basin. 


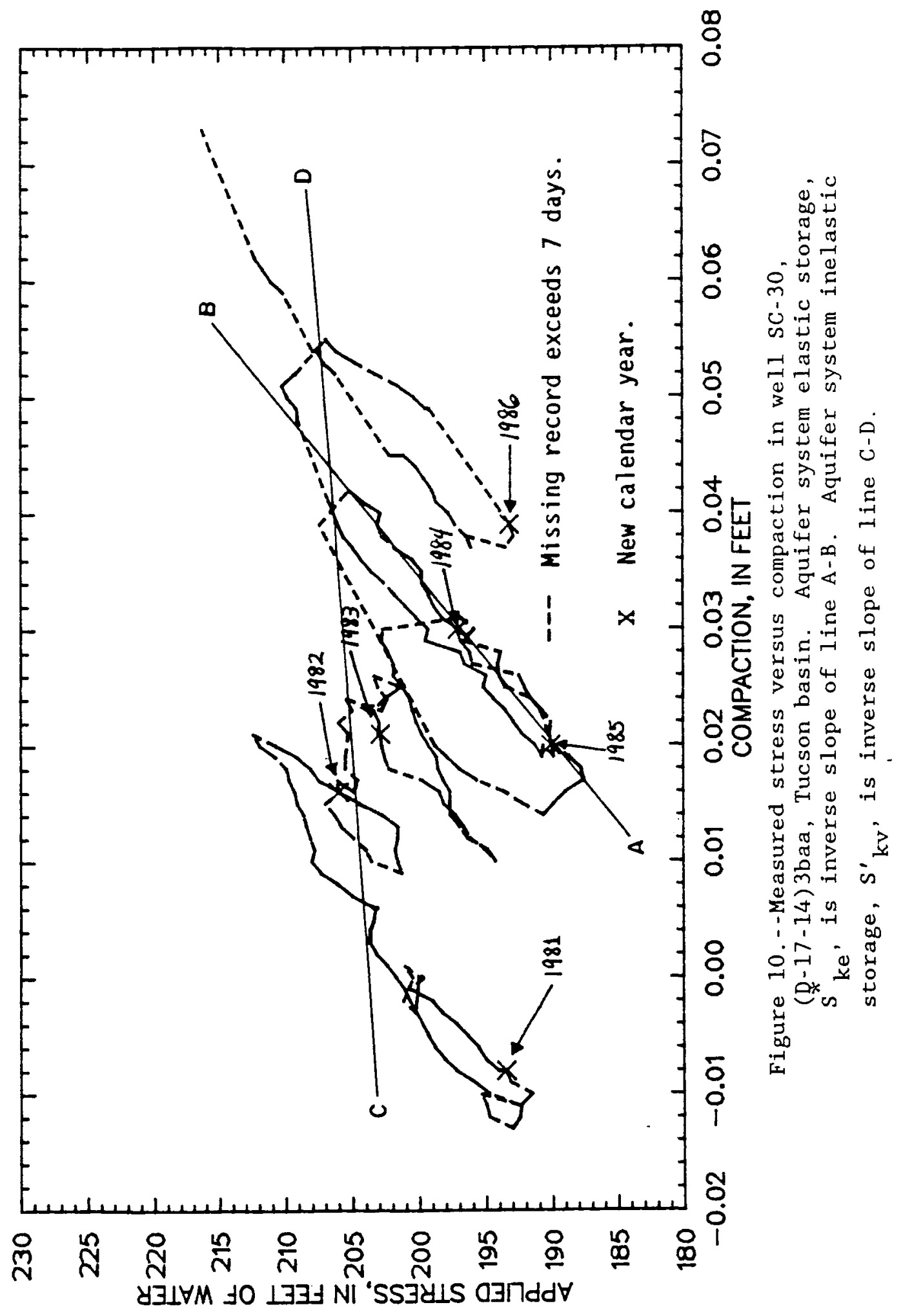




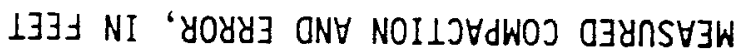

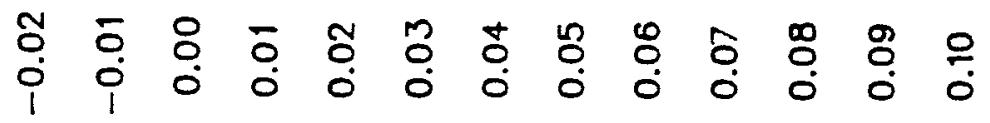

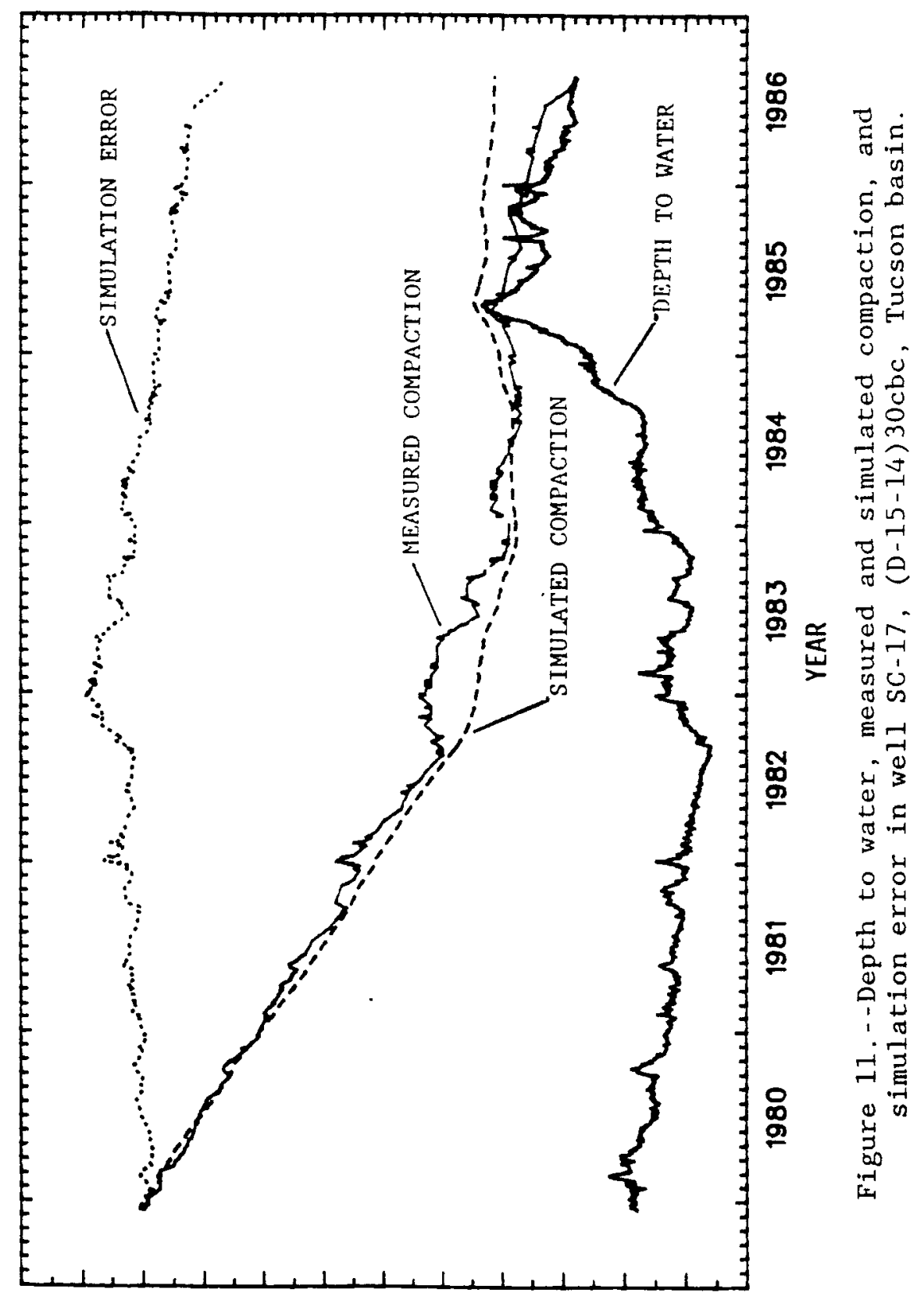

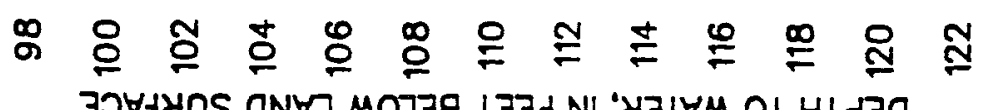

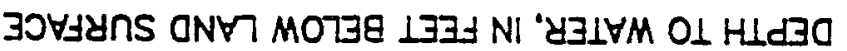




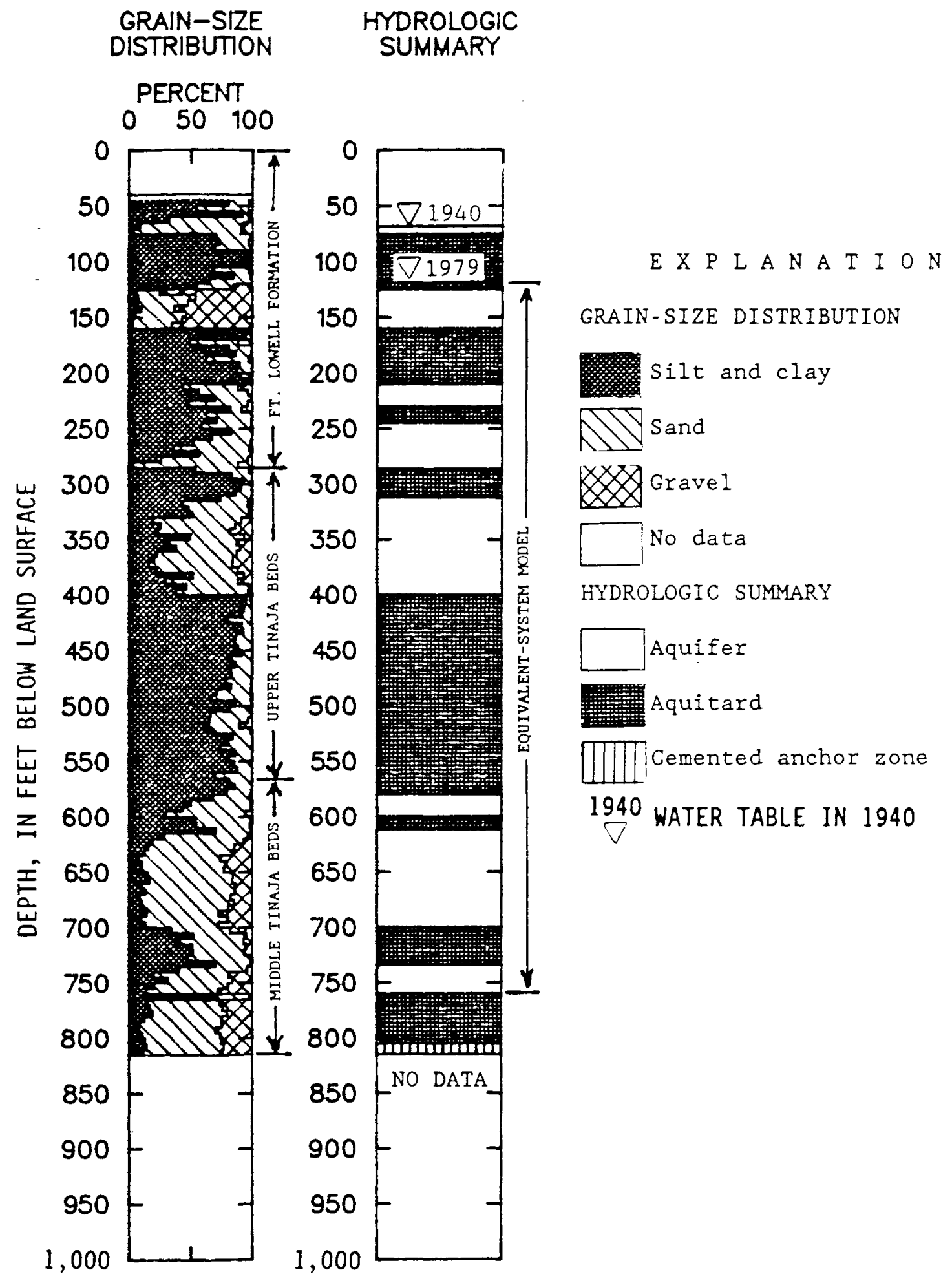

Figure 12.--Grain-size distribution and hydrologic summary for well $\mathrm{SC}-17,(\mathrm{D}-15-14) 30 \mathrm{cbc}$, Tucson basin. Lithologic data is from well (D-15-14) $31 \mathrm{cbb}$. 


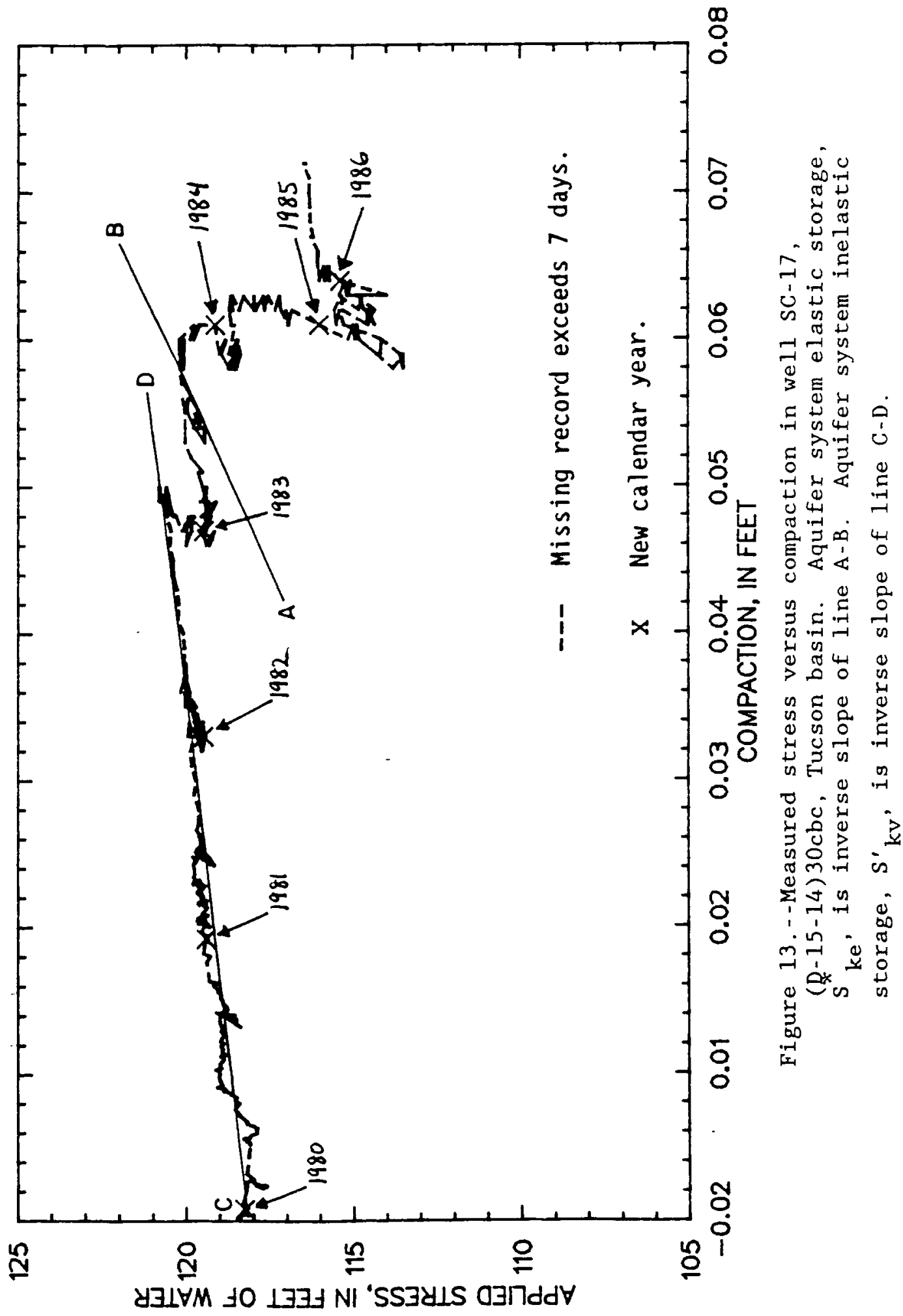


the Santa Cruz fault in the central-basin graben. Typical seasonal drawdown-recovery cycles from pumping of nearby supply wells are shown in the hydrograph for well B-76 (fig. 14). Seasonal water-level recoveries coincide with winter months, and smaller water-level recoveries coincide with summer monsoon seasons. Well B-76 fully penetrates the Fort Lowell Formation and partially penetrates the upper Tinaja beds (fig. 15). The size of hysteresis loops for stresscompaction data from well B-76 is in direct proportion to the size of the recovery events (fig. 16). Several of the larger loops did not close, which suggests that thicker aquitards in the aquifer system may not be dissipating all excess pore-water pressure for these larger drawdowns before the next seasonal drawdown resumes.

Wells C-45 and D-61 are northeast of we11 B-76 (fig. 2). Well C-45 fully penetrates the Fort Lowell Formation and partially penetrates the upper Tinaja beds. The hydrograph (fig. 17) shows barometric effects from winter storm fronts (Anderson, 1987a). Elastic compaction and seasonal water-level changes are absent (fig. 18). Almost all deformation at we11 $\mathrm{C}-45$ is rectilinearly inelastic with increasing stress. We11 D-61 is less than $0.5 \mathrm{mi}$ southeast of we $11 \mathrm{C}-$ 45 (fig. 2), fully penetrates the Fort Lowell Formation, and partially penetrates the upper Tinaja beds. As in the case of well $\mathrm{C}-45$, the hydrograph for we11 D-61 shows steady declines with no seasonal changes (fig. 17); however, unlike well C-45, inelastic compaction is curvilinear at well D-61 with increasing stress. Wel1 D-61 is twice as deep and penetrates sediments with twice the clay and silt content as well C-45; however, data from well C-45 shows twice the compaction for the same period of record. Sediments in well C-45 may be four times 


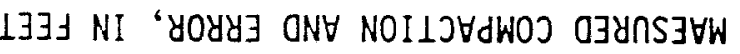

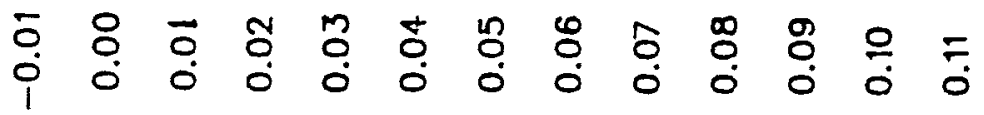

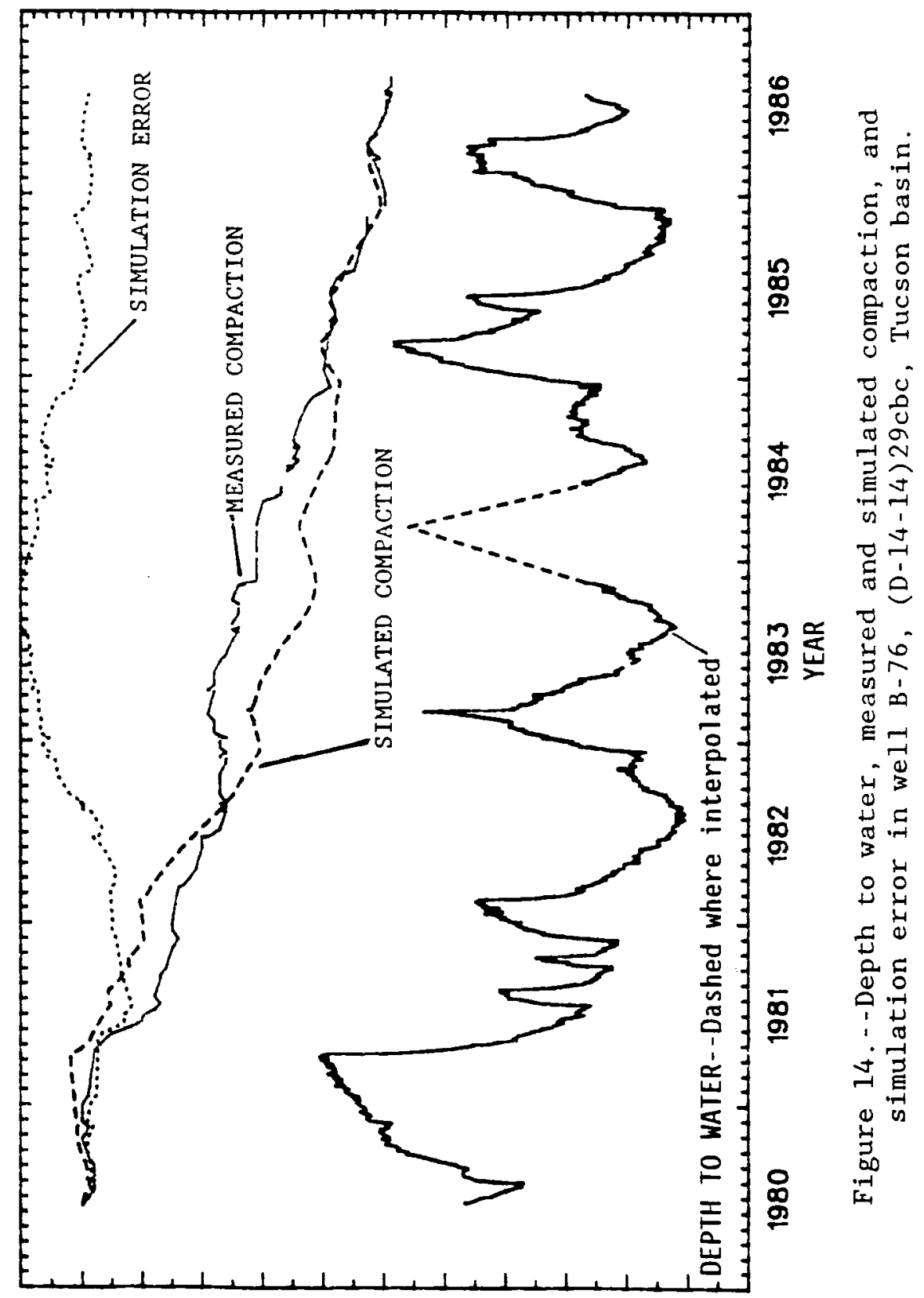

ஹ

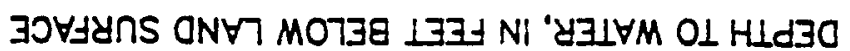




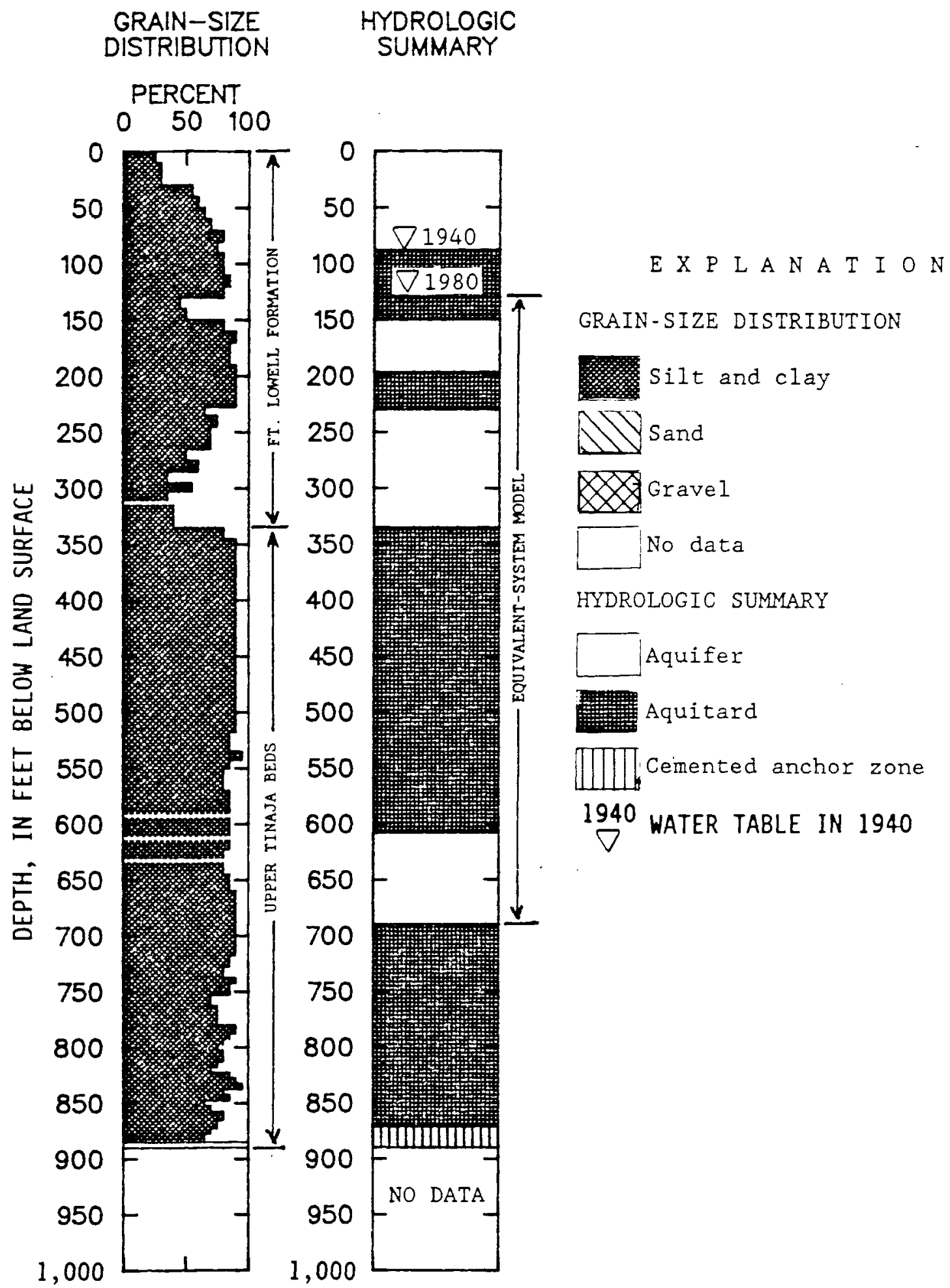

Figure 15.--Grain-size distribution and hydrologic summary for well B-76, (D-14-14)29cbc, Tucson basin. 


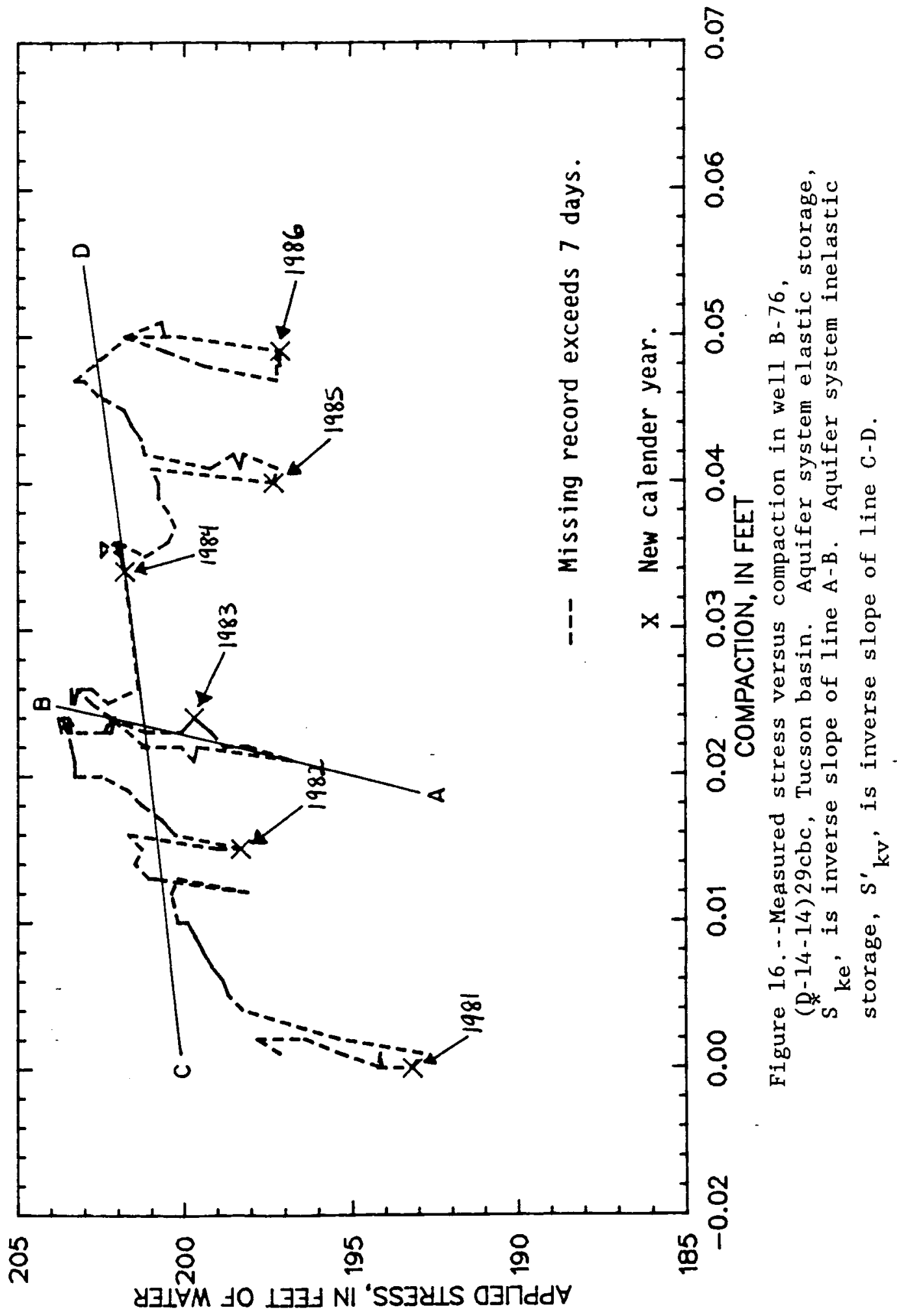




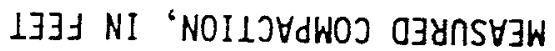

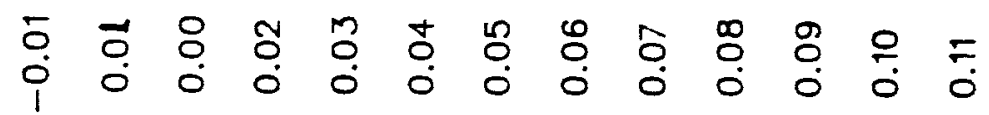

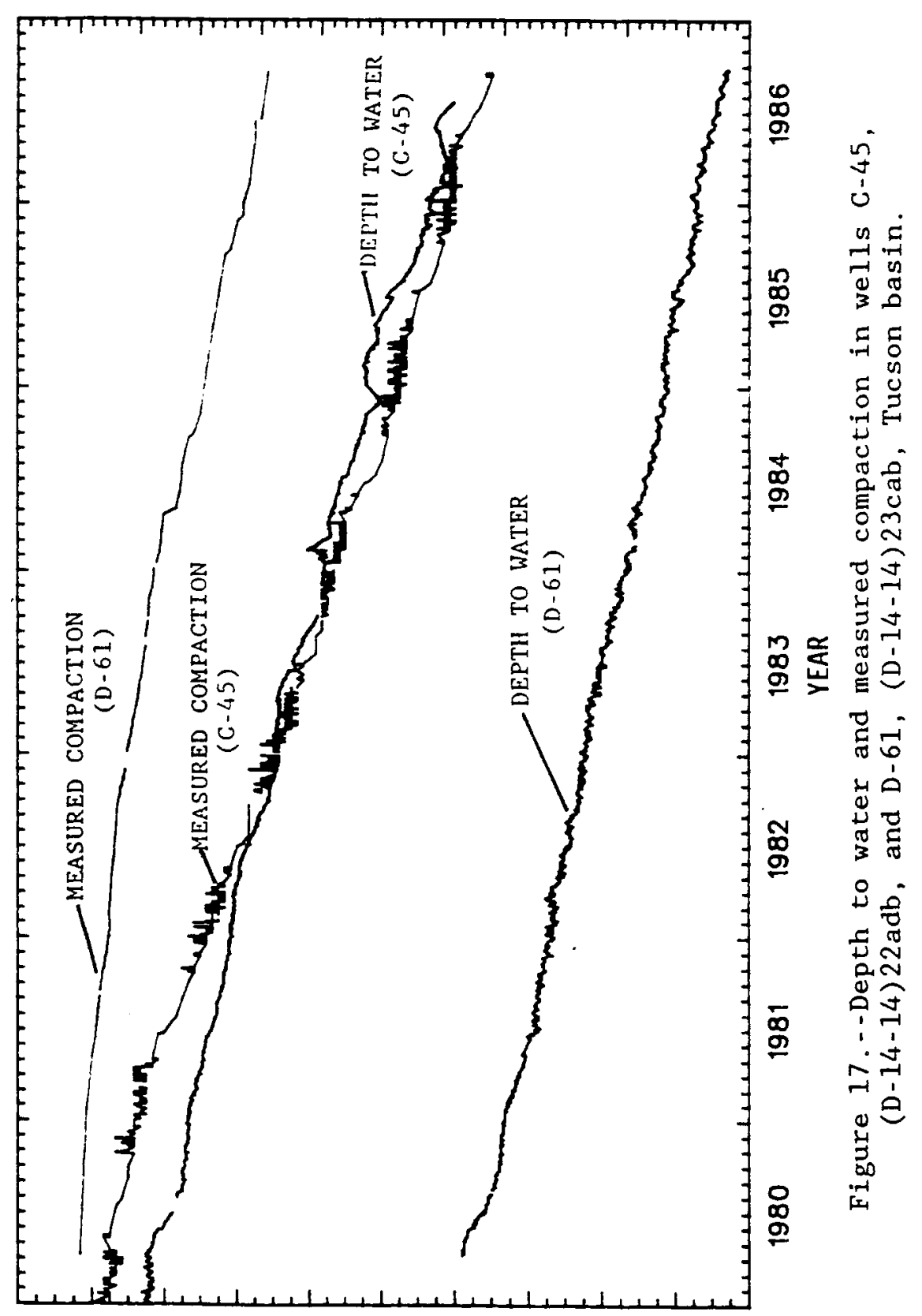

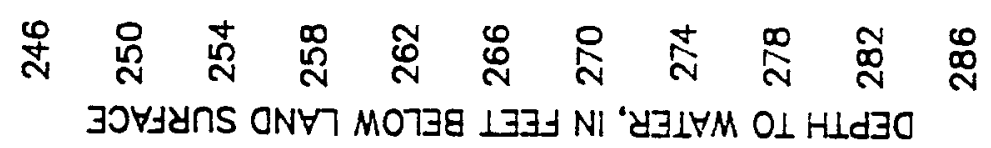




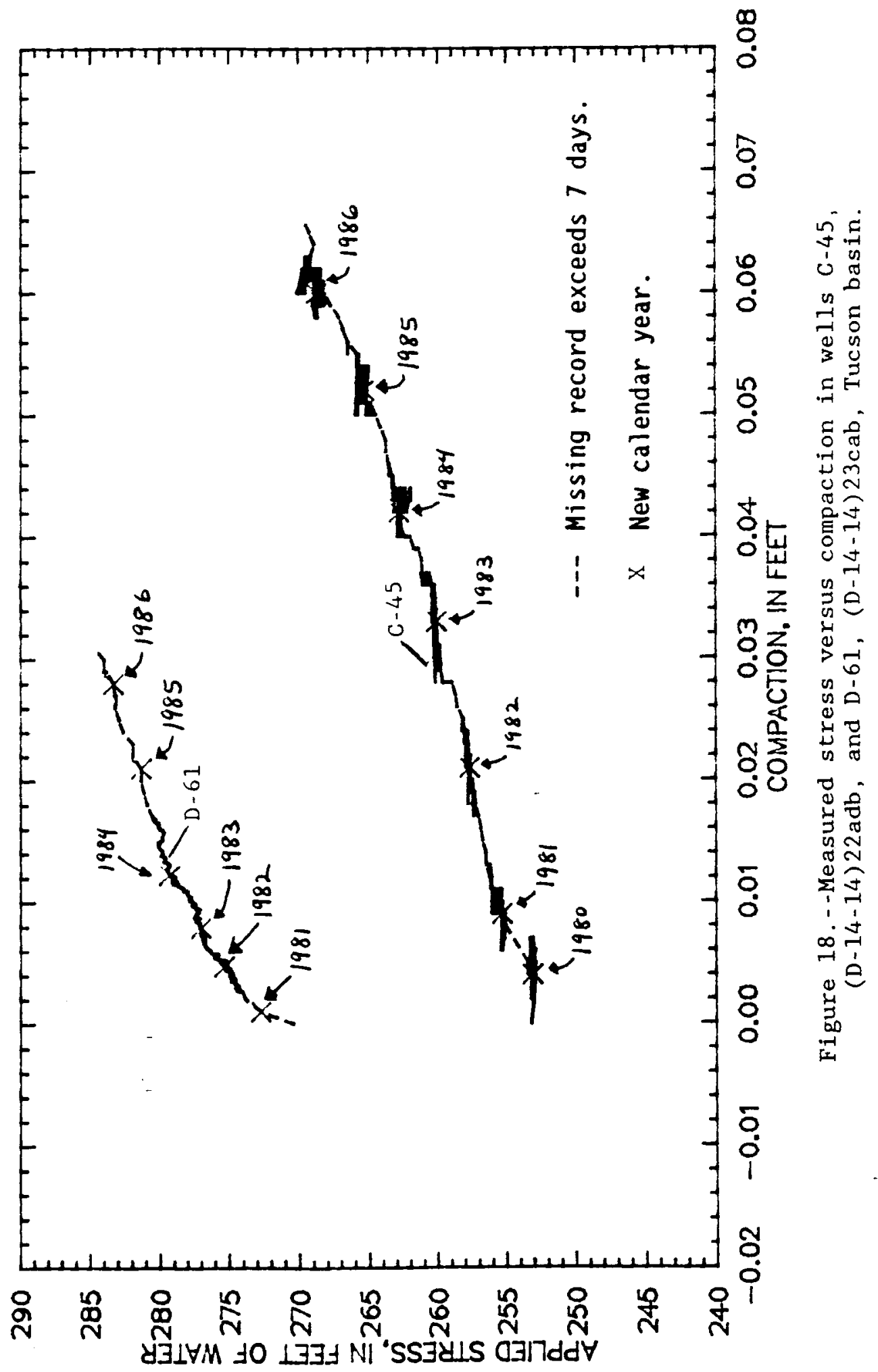


more compressible than sediments in well D-61 (fig. 18) or some measurement error may occur because of friction in well D-61.

Data from well WR-52 in north-central Tucson (fig. 2) show changes in compaction and water-level records that coincide with the pumping of water-supply wells B-10 and A-5 (fig. 19). Compaction occurs during water-level recovery, and expansion occurs during waterlevel declines from intraborehole flow that cools and shrinks the extensometer pipe. Well WR-52 fully penetrates the Fort Lowe11 Formation and the upper Tinaja beds and partially penetrates the middle Tinaja beds (fig. 20). Reverse hysteresis loops are superimposed on the curvilinear trend in stress-compaction data for well WR-52 (fig. 21). Compaction continues at a smaller rate with smaller rates of water-level decline (figs. 19 and 21).

\subsection{Extensometers in Avra Valley}

Aquifer-system compaction caused by the withdrawal of ground water is monitored by seven extensometers in Avra Valley (fig. 2). As of 1986, more than 2 years of compaction data are available at wells AF-14 and AV-25; 1 year of data indicates that almost no compaction has occurred at a third well, AF-17. Three extensometers in wells AF-14, $\mathrm{AV}-25$, and $\mathrm{AF}-17$ are in or near areas of greatest water-level declines. Four other extensometers (fig. 2) were placed in wells along the trace of the proposed Tucson aqueduct of the Central Arizona Project to monitor subsidence adjacent to the canal (Wrege and others, 1985).

We11 AF-14 is in the north-central part of Avra Valley just southwest of the largest measured land subsidence southeast of Picacho Peak (fig. 2). As in the case of well SC-30, well AF-14 has a 


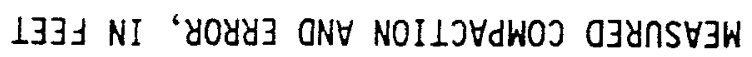

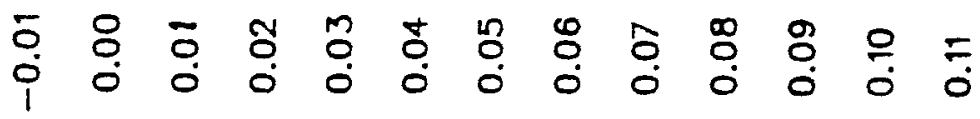

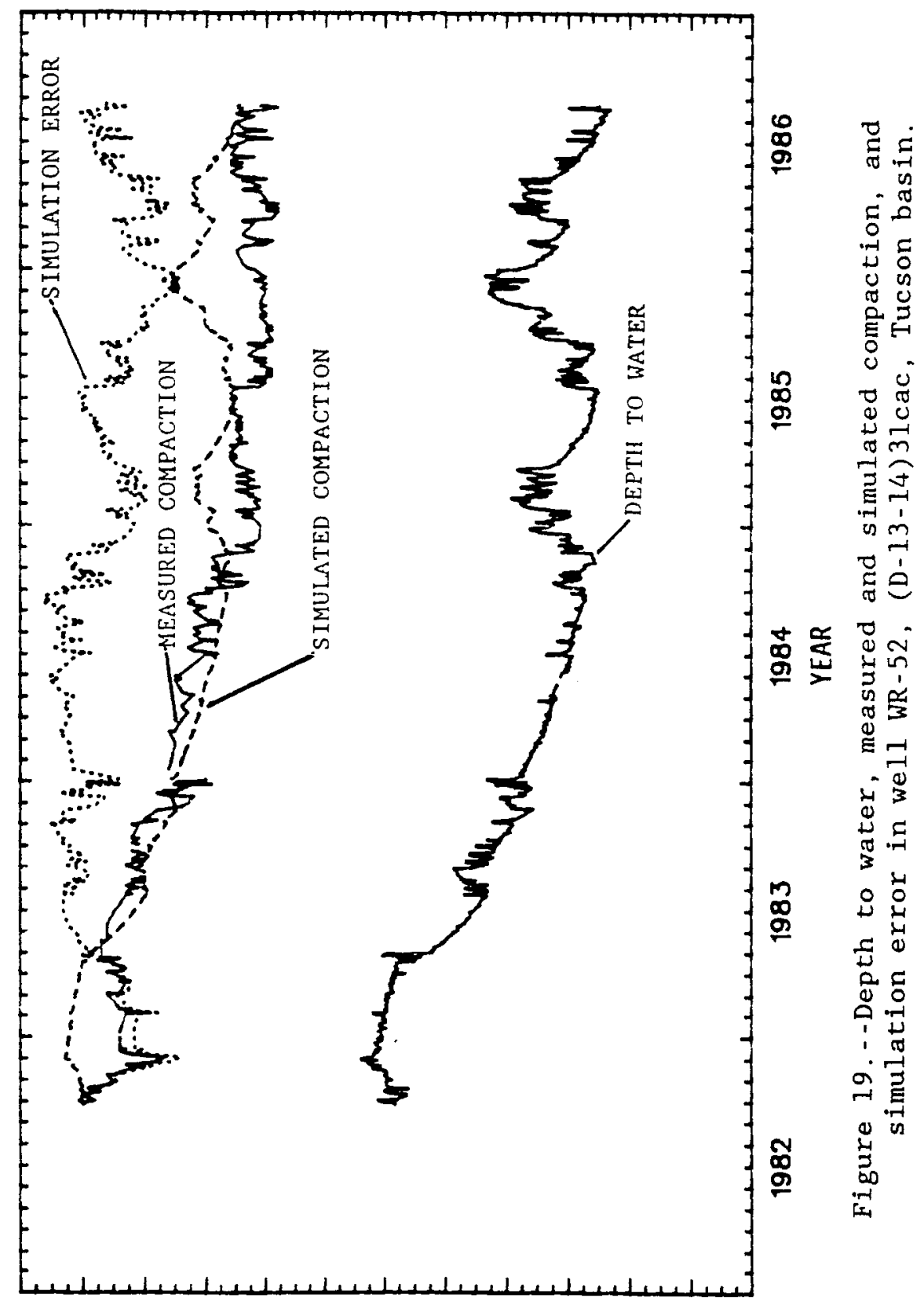

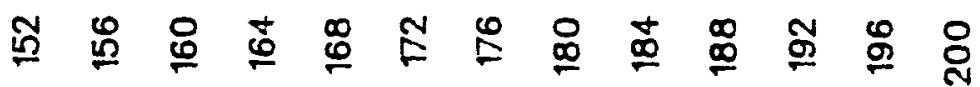

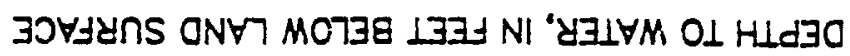




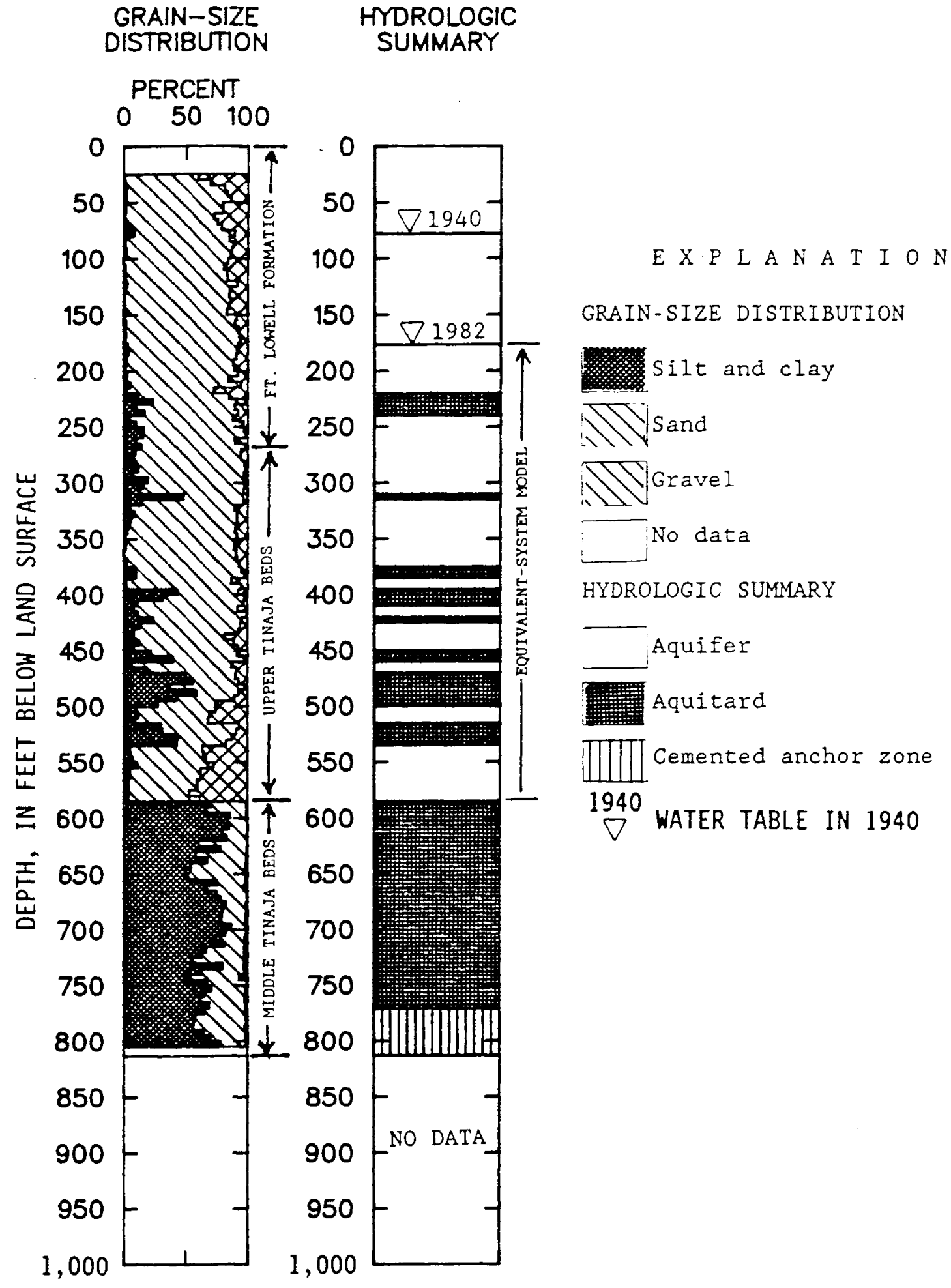

Figure 20.--Grain-size distribution and hydrologic summary for well WR-52, (D-13-14)3Icac, Tucson basin. 


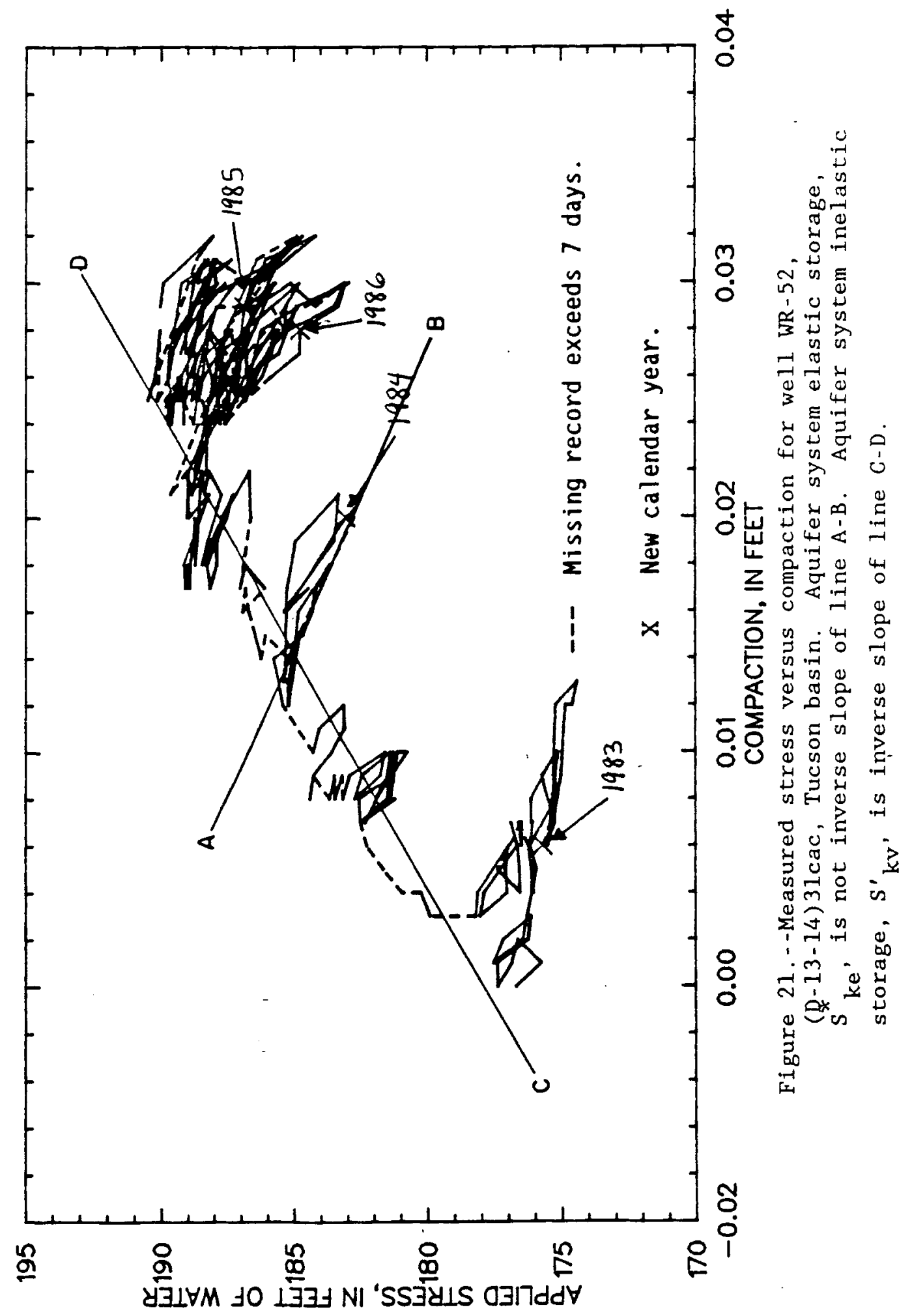


compaction and water-level record closely aligned with seasonal declines and recoveries (fig. 22). Well AF-14 fully penetrates the stratigraphic equivalent of the Fort Lowell Formation and upper Tinaja beds and partially penetrates the stratigraphic equivalent of the middle Tinaja beds (fig. 23). The stress-compaction data from well AF-14 are similar to data from well SC-30 in Tucson basin, and the graphic record shows large overlapping seasonal hysteresis loops (fig. 24).

Data from well AV-25 north of Ryan Field (fig. 2) show water-level declines of less than $10 \mathrm{ft}$ and net compaction of less than $0.01 \mathrm{ft}$ (fig. 25). The most recent data from well AV-25 shows a divergence between water levels and net compaction, which may indicate that in 1984 aquitards at the bottom of the compacting interval (fig. 26) were overconsolidated. Sediments penetrated by well AV-25 include the unsaturated stratigraphic equivalent to the Fort Lowell Formation and the stratigraphic equivalent of the saturated parts of the upper and lower Tinaja beds (fig. 26). A large number of small reverse hysteresis loops on a larger loop indicate small net compaction (fig. 27).

\section{$\underline{3.3 \text { Observed Stress and Compaction }}$}

Since 1940, water-level declines near extensometers have been on the order of several feet per year, and recovery or smaller rates of water-level decline have occurred since 1979-80. Short-term hydrographs from the extensometers show similar water-level decline and recovery patterns with seasonal cycles of less than $30 \mathrm{ft}$ combined with long-term declines of 2 to $5 \mathrm{ft} / \mathrm{yr}$. The development of perched 


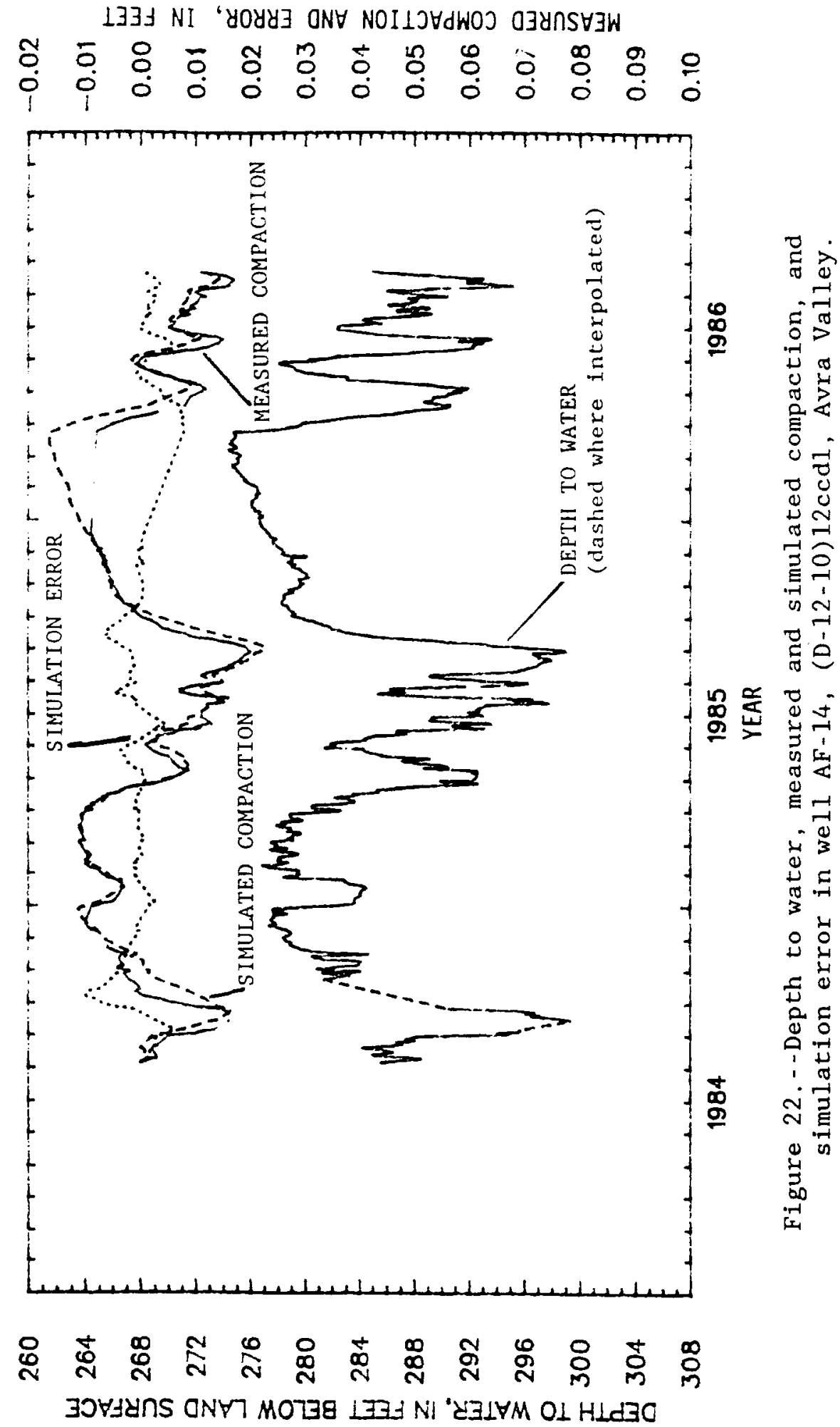




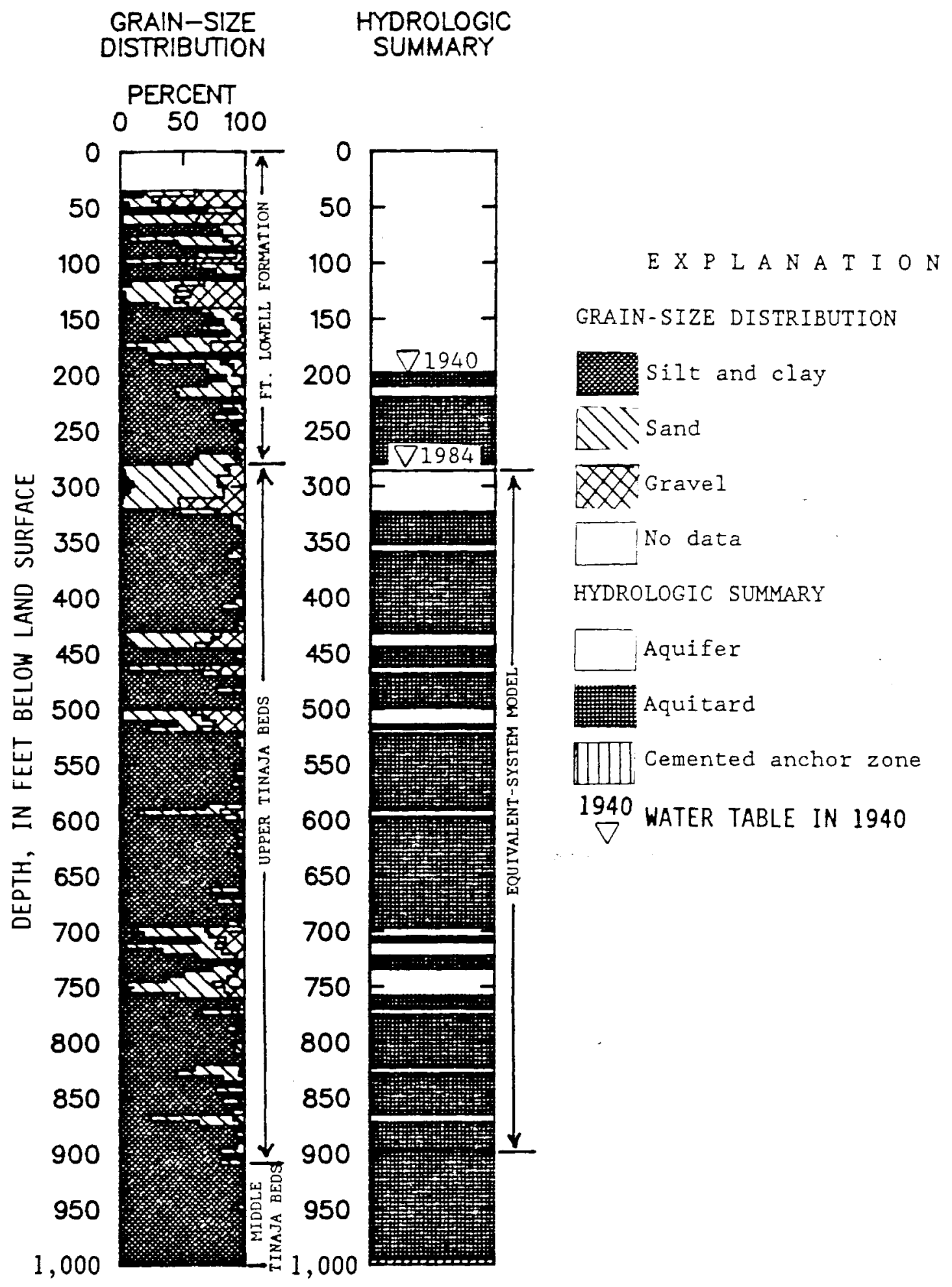

Figure 23.--Grain-size distribution and hydrologic summary for well AF14 (D-12-10) $12 \mathrm{ccdl}$, Avra Valley. Lithologic data from well (D-12-10) $12 \mathrm{cdb}$. 


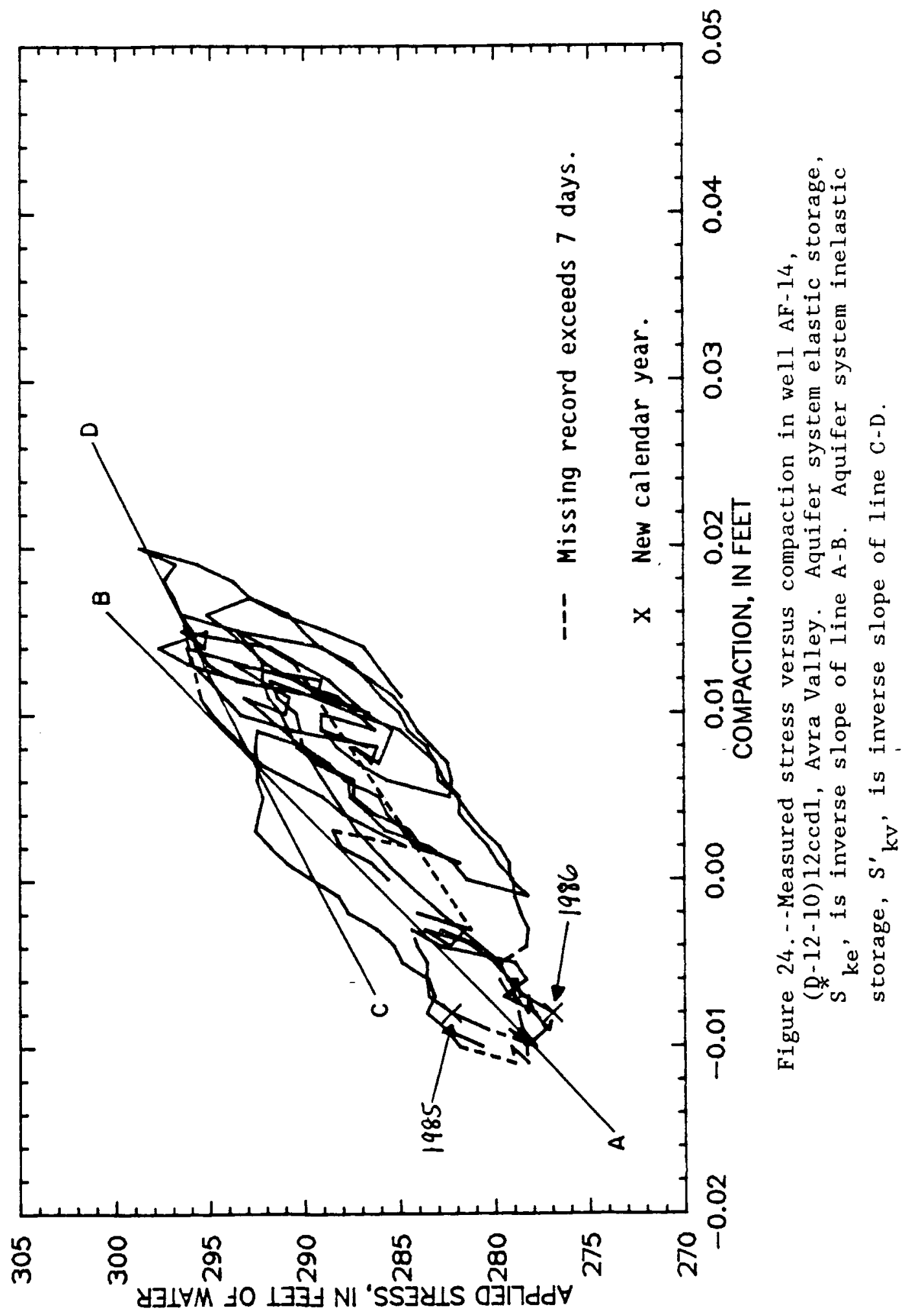




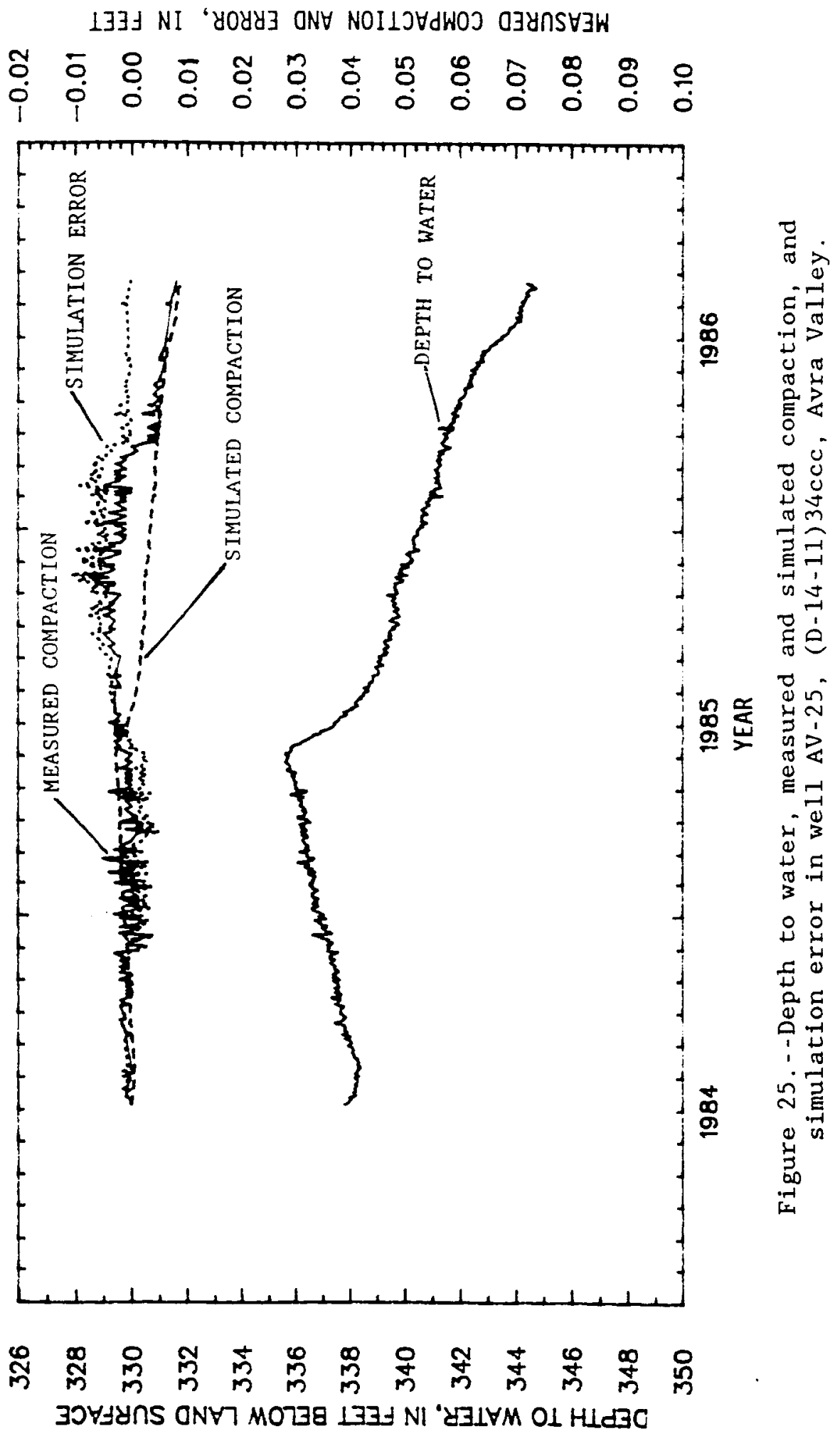




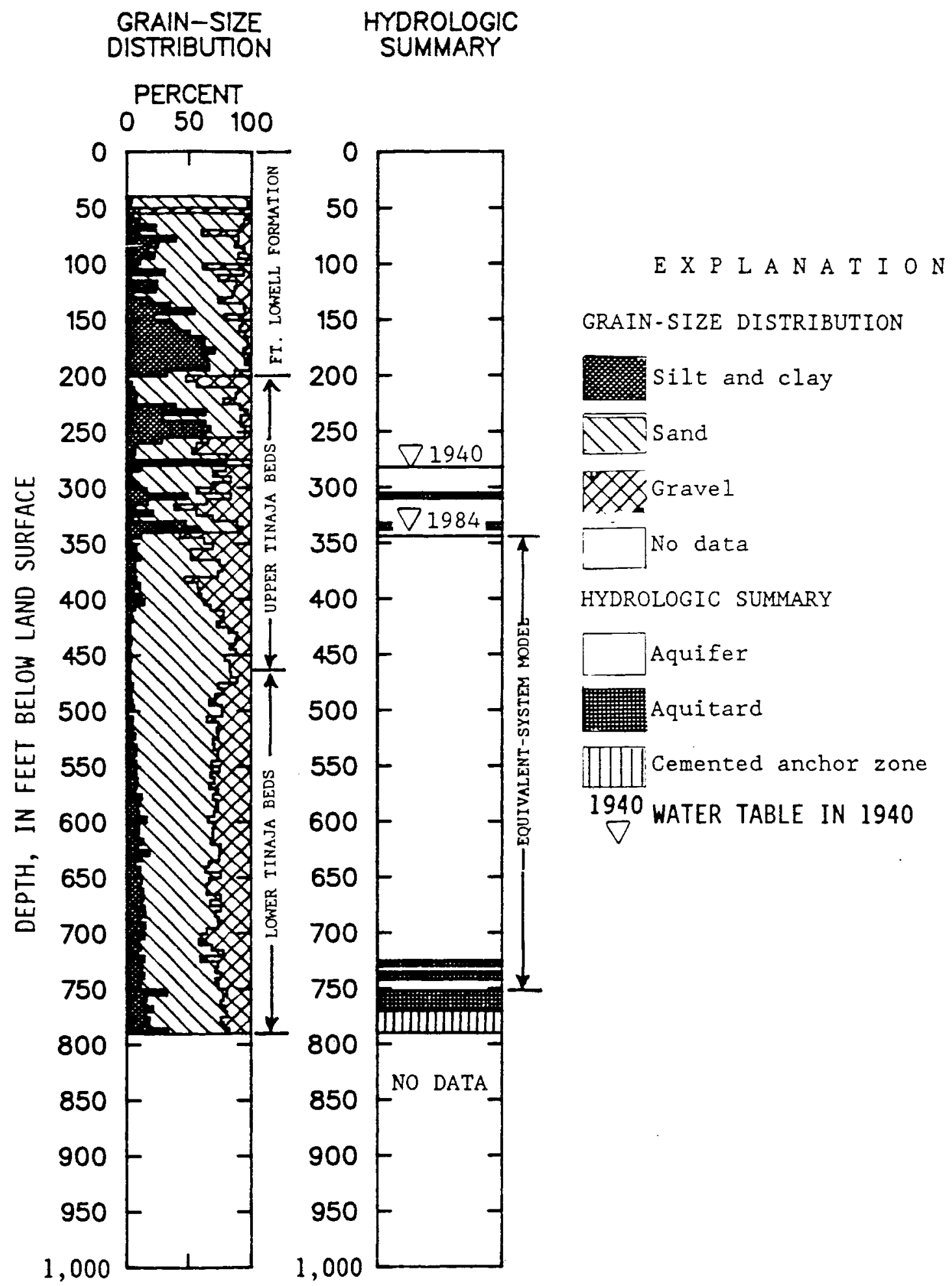

Figure 26.--Grain-size distribution and hydrologic summary for well AV-25, (D-14-11)34ccc, Avra Valley. 


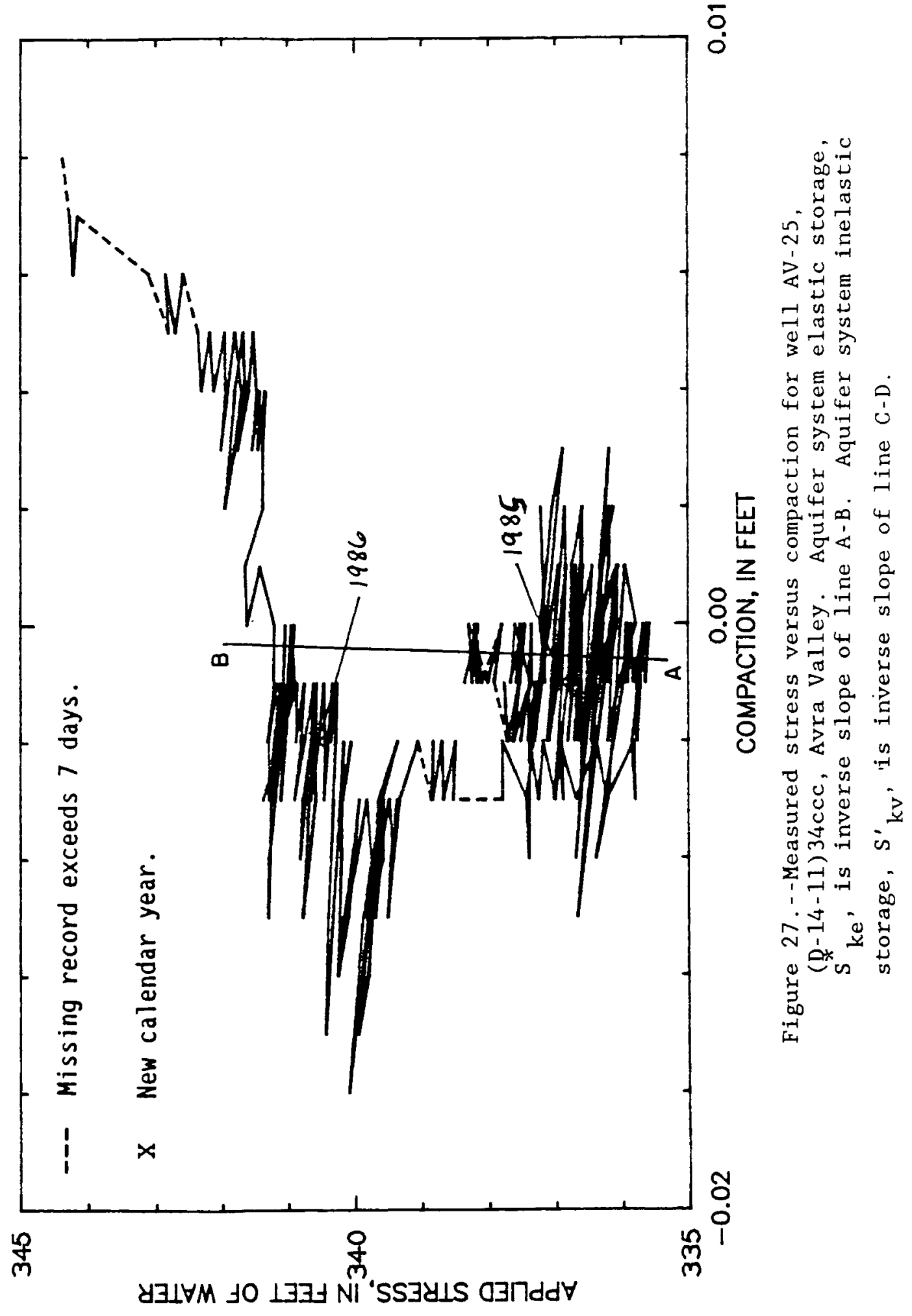


aquifers and vertical hydraulic gradients and the presence of cascading water in water-supply wells continue in both basins (Anderson, 1987a, 1988, Cuff and Anderson, 1987, Leake and Hanson, 1986, Davidson, 1973, Laney, 1973, and Wrege and others, 1985). Water-level data show vertical hydraulic gradients are largely constant through time and appear to be small in the upper $600 \mathrm{ft}$ of the aquifer system. For modeling purposes, the assumptions were made that the average hydraulic heads measured in the extensometers represent all the aquifers penetrated and that transient seepage stresses could be neglected. Because consolidation-test data of core samples were unavailable, initial estimates of preconsolidation heads are based on depths to water that coincide with measureable amounts of subsidence shown by Anderson (1987a and 1988). The estimated range of preconsolidation-stress threshold is from $150 \mathrm{ft}$ of water-level decline in the northern part of Tucson basin to $50 \mathrm{ft}$ in the southern part and from 100 to $120 \mathrm{ft}$ of water-level decline in northern Avra Valley. Since 1940, estimated water-level declines at extensometers ranged from 50 to $100 \mathrm{ft}$. Water-level declines at the two south-central extensometers at wells SC-30 and SC-17 exceeded the initial estimated preconsolidation-stress threshold of $50 \mathrm{ft}$ for the southern part of the basin. If the threshold is $100 \mathrm{ft}$ of water-level decline in the central part of Tucson basin, wells B-76, C-45, D-61, and WR-52 also may have exceeded the initial preconsolidation-stress threshold. Well AF-14 in the central part of Avra Valley and well AV-25 in the southern part also may have exceeded preconsolidation-stress thresholds of 50 to $150 \mathrm{ft}$. Small estimated time constants (table 1), decelerating waterlevel declines, closed hysteresis loops from most extensometer data, 
and water-level declines near or slightly past preconsolidation-stress thresholds collectively indicate that the active interval of compaction at most extensometers may be close to the condition of normal consolidation and that pumping is beginning to control preconsolidation-stress thresholds in parts of Tucson basin and Avra Valley.

Layering at extensometer sites can be categorized into three general groups that typify the fine- and coarse-grained layering within the Fort Lowell Formation and upper Tinaja beds. The first group, which includes wells SC-30 and AF-14, shows almost as much elastic as inelastic compaction and has a layering frequency of six layers per 100 $\mathrm{ft}$, weighted-average aquitard thicknesses of 20 to $50 \mathrm{ft}$, and 30 to 75 percent clay and silt. Wells WR-52, AV-25, C-45, and D-61 fall into a second group that shows inelastic compaction and has a layering frequency of two to three layers per $100 \mathrm{ft}$, weighted-average aquitard thicknesses of less than $20 \mathrm{ft}$, and less than 20 percent clay and silt. The third group, which includes wells SC-17 and B-76, shows inelastic compaction and has a layering frequency of fewer than two layers per $100 \mathrm{ft}$, weighted-average aquitard thicknesses of more than $50 \mathrm{ft}$, and 50 to 85 percent clay and silt.

The estimated elastic storage coefficients for the aquifer systems (table 1) spans about an order of magnitude $\left(6 \times 10^{-4}\right.$ to $\left.5 \times 10^{-3}\right)$. Elastic specific-storage values for aquitards $\left(2 \times 10^{-5} \mathrm{ft}^{-1}\right.$ to $\left.2 \times 10^{-6} \mathrm{ft}^{-1}\right)$ are comparable to values reported (1.8 $\times 10^{-6}$ to $\left.6.8 \times 10^{-6} \mathrm{ft}^{-1}\right)$ for Latrobe Valley, Australia, and San Joaquin Valley, California (Helm, 1984, and Ireland and others, 1982). Field estimates of aquitard elastic specific storage were largest for 
well AV-25 (2 $\left.\times 10^{-5} \mathrm{ft}^{-1}\right)$ and well SC-17 $\left(1 \times 10^{-5} \mathrm{ft}^{-1}\right)$, and smallest for well B-76 $\left(2 \times 10^{-6} \mathrm{ft}^{-1}\right)$. The small elastic time constants (table 1) range from a few hours for well AV-25 to 99 days for well SC17. Time constants are all consistent with the time frames of stresscompaction relations shown in figures $7,10,13,18,21$ and 24 . The aquifer-system specific-storage values $\left(2 \times 10^{-6} \mathrm{ft}^{-1}\right.$ to $\left.9 \times 10^{-6} \mathrm{ft}^{-1}\right)$ are also comparable to values $\left(2 \times 10^{-6} \mathrm{ft}^{-1}\right.$ to $\left.4 \times 10^{-6} \mathrm{ft}^{-1}\right)$ reported for San Joaquin Valley (Ireland and others, 1982, table 4).

Aquitard inelastic storage coefficients $\left(2.0 \times 10^{-3}\right.$ to

$2.1 \times 10^{-2}$ ) are an order of magnitude smaller than previously reported values $(0.06$ to 0.40$)$ for San Joaquin Valley (Ireland and others, 1982). Estimates of inelastic skeletal specific storage $\left(4.9 \times 10^{-6} \mathrm{ft}^{-1}\right.$ to $\left.6.5 \times 10^{-5} \mathrm{ft}^{-1}\right)$ are also about an order of magnitude lower than values for the San Joaquin Valley $\left(1 \times 10^{-4} \mathrm{ft}^{-1}\right.$ to $7 \times 10^{-4} \mathrm{ft}^{-1}$ ). Similarly, the inelastic time constants (table 1) are between 0.01 and 3.1 years, which are orders of magnitude smaller than estimates for the San Joaquin Valley (Ireland and others, 1982). The ratios of elastic specific-storage values to inelastic specific-storage values (2 to 27 ) for aquitards are also an order of magnitude smaller than values (32 to 126) reported for the San Joaquin Valley (Ireland and others, 1982). The small inelastic values may further indicate that the aquifer systems are still in transition to predominantly inelastic compaction. If so, long-term inelastic values may still increase before beginning to decrease because of increased compaction. Inelastic specific-storage values estimated for the initial 6 years of record may represent historical compaction but may not represent long-term inelastic specific storage. 
CHAPTER 4

\section{SIMULATION OF AQUIFER-SYSTEM COMPACTION}

Simulations of aquifer-system compaction were made at six sites in order to better understand controlling factors of compaction and to refine estimates of aquifer and aquitard hydraulic parameters. A one-dimensional, finite-difference model of aquifer-aquitard compaction developed by Helm $(1974,1975)$-hereafter referred to as the Helm model was used to calculate aquifer-system compaction in the shallow sediments. The Helm model uses measured head as applied stress, which transforms into change in applied stress. The model calculates compaction that can be compared with the measured compaction that is used for calibration. Because measured compaction data represent only a few multiples of the estimated time constants or represent both recovery and decline periods, all measured data were used for calibration.

One-dimensional simulation of compaction is considered reasonable for aquitards within large aquifer systems. Large aquifer systems with permeability contrasts of several orders of magnitude between aquifers and aquitards exhibit flow that is predominantly horizontal in the aquifers and vertical in the aquitards (Neuman and Witherspoon, 1969). Strictly vertical simulation of compaction and flow in aquitards also was used in three-dimensional models that 
simulate compaction and ground-water flow (Neuman and others, 1982; S.A. Leake, hydrologist, U.S. Geological Survey, written commun., 1987).

\subsection{Mode1 Structure}

The Helm (1974, 1975) model computes compaction in a layer using known boundary stresses, layer thickness, and hydraulic parameters for the compacting layer and adjacent aquifer. Changes in applied stress are calculated at the boundary of a compacting layer from water levels measured in the field (Lofgren, 1968). The vertical effective-stress distribution within the compacting layer is determined by solving the linear partial differential equation (Scott, 1963, p. 184) as

$$
\left(\mathrm{K}_{\mathrm{v}}^{\prime} / \mathrm{S}_{\mathrm{s}}^{\prime}\right) \partial^{2} \mathrm{u} / \partial \mathbf{z}^{2}=\partial \mathrm{u} / \partial \mathrm{t}-\partial \mathrm{p}_{\mathrm{a}} / \partial \mathrm{t}
$$

where

$$
\begin{aligned}
& \mathbf{p}_{\mathbf{a}}=\text { total applied stress at aquifer-aquitard boundary, } \\
& \mathbf{z}=\text { vertical coordinate, and } \\
& \mathbf{t}=\text { time. }
\end{aligned}
$$

In terms of effective stress, equation (22) simplifies to:

$$
\left(\mathrm{K}_{\mathrm{v}}^{\prime} / \mathrm{S}^{\prime}{ }_{\mathrm{s}}\right) \partial^{2} \mathrm{p}^{\prime} / \partial \mathrm{z}^{2}=\partial \mathrm{p}^{\prime} / \partial \mathrm{t}
$$

where the term $\partial \mathrm{p}_{\mathrm{a}} / \partial \mathrm{t}$ becomes the value of $\partial \mathrm{p}^{\prime} / \partial \mathrm{t}$ at the aquiferaquitard boundary. Specific storage, $\mathbf{S}^{\prime} \mathbf{s}^{\prime}$, is a combined term for both skeletal specific storage, $\mathbf{S}^{\prime}{ }_{\mathbf{s k}}$, and for compressibility of water, $\mathbf{s}_{\mathbf{s w}}$. Whenever skeletal specific storage is greater than compressibility of water, compressibility of water can be ignored, which leaves specific 
storage equal to skeletal specific storage. When the stress at the boundary is applied instantaneously and held constant thereafter, the change in total applied stress, $\partial \mathrm{p}_{\mathbf{a}} / \partial \mathrm{t}$, drops out, and equation 22 becomes similar to equation 9 :

$$
\left(K_{v}^{\prime} / s^{\prime}\right) \partial u^{2} / \partial z^{2}=\partial u / \partial t
$$

Note that equation 22 is more applicable than equation 24 whenever the change in effective stress is caused by factors other than reduction of head in the aquifers within the aquifer system such as a declining water table, land excavation, or other changes in the total stress. Equation 24 is Terzaghi's (1943) formulation of the diffusion equation for $\mathbf{S}_{\text {sk }}{ }^{>S_{\text {sw }}}$.

The one-dimensional numerical equation using a time-centered finite-difference approximation for solution of equation 23 for a homogeneous aquitard with constant mesh spacing, $\Delta z$, is

$$
-A p^{\prime} \underset{j+1}{n}+B p_{j}^{\prime n}-C p_{j-1}^{\prime n}=D
$$

where

$$
\begin{aligned}
& A=C=\left(K^{\prime}{ }_{v} \Delta t\right) /\left(2 S^{\prime}{ }_{s} \Delta z^{2}\right), \\
& B=1+(A+C), \\
& D=A p^{\prime}{ }_{j+1}^{n-1}+E p^{\prime}{ }_{j}^{n-1}+C p_{j-1}^{\prime n-1}, \text { and } \\
& E=1-(A+C),
\end{aligned}
$$

with

$$
\begin{aligned}
& S^{\prime}{ }_{s}=S^{\prime}{ }_{s k v} \text { when } p^{\prime n-1}=p_{j}^{\prime \frac{n-1}{\max }}{ }_{j} \text { or } \\
& S^{\prime}{ }_{s}=S^{\prime}{ }_{s k e} \text { when } p^{\prime n-1}=p_{j}^{\prime n-1},
\end{aligned}
$$


where

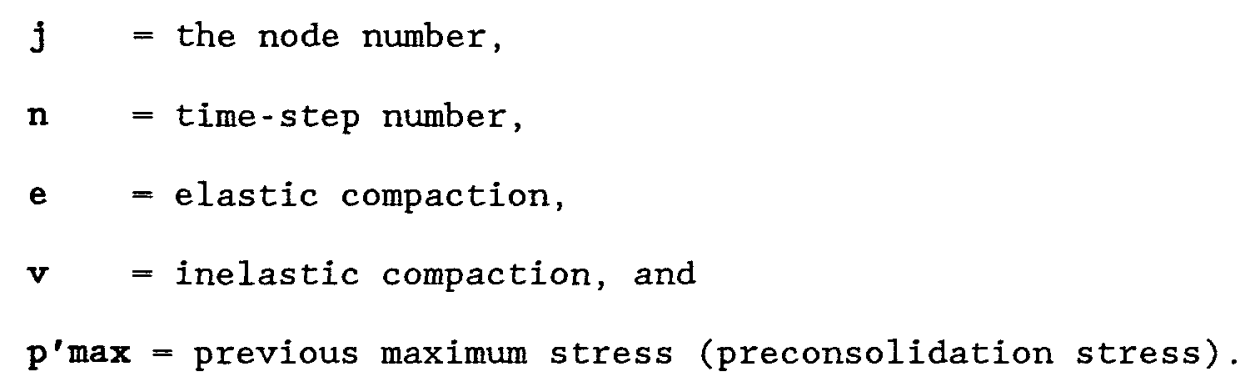

The term $\mathbf{p}^{\prime} \max _{\mathbf{j}}$ is the preconsolidation stress for node $j$ at which inelastic compaction resumes, and the term $\mathrm{P}^{\prime} \mathrm{e}$ merely specifies when the current effective stress at a specified node is less than $\mathrm{p}^{\prime} \max _{j}$. Preconsolidation stress for each node is automatically updated on the basis of this calculation. The numerical coefficient, D, is composed of known values from the last time step. Helm $(1974,1975)$ uses a modified form of a forward and backward substitution method developed by Thomas (Remson and others, 1971) to solve the set of simultaneous equations for the effective stress at each node for the current time step. The model determines which value of $S^{\prime}{ }_{S}$ is used on the basis of the value of $p^{\prime}$ in relation to the updated value of $p^{\prime} \max _{j}$ at the beginning of each time step. Initial values of elastic and inelastic specific storage, vertical hydraulic conductivity, and past maximum effective stress are elliptically interpolated between user-specified values at the aquitard midplane and the aquifer-aquitard boundary. Change in storage of each element is then calculated from the average change in effective stress at each node multiplied by the appropriate value of $\mathbf{S}$ ' $\mathbf{S}$. The total compaction in the aquitard is the 
sum of the elemental changes in storage multiplied by the thickness of the elements, $\Delta \mathbf{z}$, and is expressed as

$\Delta b^{\prime}=\Delta z(0.5)\left[S^{\prime}\right.$ skv $j_{j=1}^{J_{\Sigma}^{1}}\left(\Delta p_{v j}^{n}+\Delta p_{v j+1}^{n}\right)-S^{\prime}$ ske $\left.J_{j=1}^{\Sigma_{i}^{1}}\left(\Delta p_{e j}^{n}+\Delta p_{e j+1}^{n}\right)\right]$,

where

$\Delta \mathbf{b}^{\prime}=$ change in aquitard thickness,

$\Delta p_{e j}^{n}=p^{\prime} \max _{j}^{n}-p_{j}^{\prime n}$,

$\Delta \mathrm{p}_{\mathrm{vj}}^{\mathrm{n}}=\mathrm{p}^{\prime} \max _{\mathbf{j}}^{\mathrm{n}}-\mathrm{p}^{\prime} \max _{j}^{\mathrm{o}}$,

$\mathrm{J} \quad=$ total number of nodes, and

$\mathrm{J}-1=$ total number of elements.

In equation 25 when $\mathrm{p}^{\prime}{ }_{\mathbf{j}}^{\mathrm{n}}=\mathrm{p}^{\prime} \max _{\mathbf{j}}^{\mathrm{n}}$, the term $\Delta \mathrm{p}_{\mathrm{ej}}^{\mathrm{n}}$ goes to zero and compaction progresses along the inelastic curve at node $\mathbf{j}$. Because $p^{\prime} \max _{j}^{n}$ is continually being updated during inelastic compaction, the term $\Delta \mathbf{p}_{\mathbf{v j}}^{\mathrm{n}}$ automatically accumulates the inelastic component of $\Delta \mathrm{b}$.

Total aquifer-system compaction, $\Delta \mathbf{b}^{*}$, is the sum of aquitard and aquifer compaction, $\Delta \mathbf{b}^{*}=\Delta \mathbf{b}^{\prime}+\Delta \mathrm{b}$, at each time step. Compaction of the aquifer, $\Delta b$, is calculated on the basis of the change in applied stress, is calculated directly from the user-supplied water-level data, is assummed to be fully recoverable, and does not express a time lag:

$$
\Delta \mathrm{b}=\mathrm{s}_{\mathrm{ske}}(\Sigma \mathrm{b}) \Delta \mathrm{p}_{\mathrm{v} 1}^{\mathrm{n}}
$$

To avoid error from frequent transition between exclusively elastic and inelastic conditions, the time steps, $\Delta t$ are further controlled by a user-specified maximum subtime step. To insure spatial accuracy and numerical stability, the user-specified $\Delta \mathbf{z}$ should be smal1; however, Helm (1984) suggested that it need be no smaller than $3 \times 10^{-3}\left(\Delta t K^{\prime}{ }_{v} / S^{\prime} \text { ske }\right)^{3 / 2}$. 
The Helm model also can use a weighted-average thickness (equation 21) to determine the cumulative compaction from multiple beds. The calculated time-dependent compaction, $\Delta \mathrm{b}^{\prime}$, for one idealized bed is multiplied by an equivalent number, $\mathbf{N}_{\mathbf{e}}$, of beds, where the product, $\mathrm{N}_{\mathbf{e}} \mathrm{b}^{\prime}$ oe' must equal the measured aggregate thickness of actual beds, $\sum_{i=1}^{N} b^{\prime}{ }_{0 i}$. The calculated product, $N_{e} \Delta b^{\prime}$, is then added to $\Delta b *$ and used to calibrate the compaction simulation to measured compaction of the aquifer system.

The Helm model also can simulate stress-dependent hydraulic parameters, $\mathbf{K}_{\mathbf{v}}, \mathbf{S}^{\prime}{ }_{\mathbf{s k v}}$, and $\mathbf{S}{ }^{\prime}{ }_{\text {ske }}$. Stress-dependent parameter values decrease with increasing stress, thus decelerating the rate and amount of compaction through time. This option was not used because reliable estimates of preconsolidation stresses are unavailable and because simulations for this study are for small ranges of $\operatorname{strain}\left(<2 \times 10^{-4}\right)$. The assessment of stress-dependent parameters by Helm (1976) suggests that little error is generated through the use of constant hydraulic parameters for simulations of several decades.

\subsection{Model Calibration}

A water-table and confined, equivalent-system, homogeneous, and linear approach to compaction simulation was used (fig. 6) to align the compaction modeling with ongoing areal ground-water flow-model development (Anderson, 1983). The depth to the midplane of the equivalent-system aquitard was estimated as the thickness-weighted average of midplane depths for all aquitards in the active compaction 
interval. All equivalent systems are assumed to be doubly draining and every aquitard is bounded by an aquifer layer at each modeled location.

Field estimates of hydraulic conductivity and aquifer and aquitard specific storage were varied during calibration (table 1 ). Field estimates represent homogeneous, constant, average values applied uniformly over the modeled interval (Riley, 1969). The estimates of weighted-average aquitard thickness and total aquifer and aquitard thickness were restricted to the saturated interval at the beginning of the simulation period. Estimates of aquifer storage and hydraulic conductivity generally were derived from interpretations of aquifertest data from nearby wells.

The water-level data at each extensometer were directly used to generate a single applied stress history of daily values that, in turn, was used to simulate equivalent-system compaction. Because of the small estimated elastic time constants and small amounts of measured compaction, daily time steps were subdivided into ten subtime steps that were used for all simulations. To minimize initialcondition error, the maximum preconsolidation-stress range was set initially to a condition of normal consolidation throughout the aquitard half thickness of the equivalent system. Thus, the initial effective-stress distribution is equal to the past maximum effective stress throughout the aquitard.

The calibration process was trial-and-error adjustment of model parameters. Adjustments were made to parameters that were based on the least reliable field estimates. When the simulated compaction appeared to closely fit the measured compaction, additional adjustments were made, and the response of two measures of error mean error and 
rate of error growth were noted. Calibration was complete when the value of mean error and the error-growth rate was near or below the estimated resolution of the measured compaction data.

The mean error was the mean of the residuals measured compaction minus simulated compaction-for each day that a value of measured compaction was available. The mean error and the standard deviation of this error could easily be related to the resolution of the measured data of $\pm 0.003 \mathrm{ft}$. A linear regression was also performed on the residual errors through time to quantify the error-growth rate during the simulation period. Error-growth rate was used to estimate the temporal growth of the inelastic component of error. The assumption was made that any periodic elastic error would have little effect on the long-term growth in residual error.

\subsection{Model Results}

The curves showing historical simulated compaction and respective simulation error are included with the measured compaction (figs. 8, 11, 14, 19, 22, and 25). The simulations fit within 10 percent of their respective total measured compaction at four of the six sites (table 2). Mean errors ranged from -0.007 to $0.004 \mathrm{ft}$, which are near the resolution of the extensometer data of $\pm 0.003 \mathrm{ft}$. A large percentage of the error at wells WR-52 and AV-25 may be caused by the transient thermal effect on the elastic compaction. A large percentage of the error at we1l AV-25 also is partly because of the small amount of net compaction, less than $0.01 \mathrm{ft}$ as of August 1986. The average growth of the residual error ranged from $2.3 \times 10^{-3} \mathrm{ft} / \mathrm{yr}$ at well AF-14 to $-4.0 \times 10^{-3} \mathrm{ft} / \mathrm{yr}$ at well $\mathrm{AV}-25$ during the simulation period. 
Simulations for wells SC-30, SC-17, WR-52, and AF-14 showed small

positive error growth that represents progressive underestimation of compaction. Simulations for wells B-76 and AV-25 showed small negative error growth that represents progressive overestimation of compaction. Simulations that used the equivalent-system option best fit the periods of decline and the seasonal cycles. Recoveries in 1982-83 at well SC30 and in 1985 at we11 SC-17 are examples of poor model fit in the elastic range and may be attributed in part to the nonlinear increase of elastic storage during sustained recovery or to differing hydrologic conditions within the aquifer system.

The geometric components are similar for the three pairs of extensometers at wells SC-30 and AF-14, wells SC-17 and B-76, and we11s WR-52 and AV-25 (table 2). All simulations except the simulation for well B-76 used the initial estimated equivalent thickness. Measured compaction at well B-76 could not be simulated by the model using reasonable hydraulic components without decreasing the equivalent thickness to half the estimated value. Using half the equivalent thickness would be similar to having several additional small aquifer layers at a site with few lithologic data.

The aquitard skeletal elastic specific-storage values are similar to values $\left(2 \times 10^{-6} \mathrm{ft}^{-1}\right.$ to $\left.7 \times 10^{-6} \mathrm{ft}^{-1}\right)$ reported for other areas (Ireland and others, 1982, and Helm, 1984) and are close to the field estimates (tables 1 and 2 ). The aquitard skeletal inelastic specific-storage values from simulations for wells SC-17 and B-76 were also similar to values reported for combined water-table and confined aquifer models from San Joaquin Valley (Ireland and others, 1982). The inelastic-model values are about four times larger than field estimates 
Table 2.--Summary of Helm model aquifer-system components for selected extensometer sites, Tucson basin and Avra Valley.

\begin{tabular}{|c|c|c|c|c|c|c|}
\hline \multirow{2}{*}{$\begin{array}{l}\text { Helm-model } \\
\text { components }\end{array}$} & \multicolumn{4}{|c|}{ Tucson basin } & \multicolumn{2}{|c|}{ Avra Valley } \\
\hline & $\mathrm{SC}-30$ & $\mathrm{SC}-17$ & $B-76$ & WR-52 & $\mathrm{AF}-14$ & AV -25 \\
\hline \multicolumn{7}{|l|}{$\begin{array}{l}\text { Aquitard thickness: } \\
\text { Cumulative thickness, }\end{array}$} \\
\hline $\begin{array}{c}\text { in feet. . . . . . . . . . . . } \\
\text { Equivalent thickness, }\end{array}$ & 315 & 324 & 306 & 274 & 463 & 18 \\
\hline $\begin{array}{l}\text { in feet................. } \\
\text { Weighted-average depth to }\end{array}$ & 24.4 & 72.8 & 97.1 & 16.5 & 46.1 & 6.1 \\
\hline $\begin{array}{l}\text { midplane, in feet........ } \\
\text { Vertical hydraulic }\end{array}$ & 503 & 437 & 443 & 415 & 605 & 600 \\
\hline $\begin{array}{l}\text { conductivity, in feet per } \\
\text { year................. }\end{array}$ & $3.3 \times 10^{-3}$ & $4.9 \times 10^{-2}$ & $4.9 \times 10^{-2}$ & $3.3 \times 10^{-3}$ & $1.7 \times 10^{-2}$ & $3.3 \times 10^{-3}$ \\
\hline $\begin{array}{l}\text { Minimum preconsolidation }{ }^{2} \\
\text { stress at } t=0 \text {, as depth }\end{array}$ & & & & & & \\
\hline $\begin{array}{l}\text { to water, in feet...... } \\
\text { Maximum preconsolidation } \\
\text { stress at } t=0 \text {, as depth }\end{array}$ & 200 & 116 & 197 & 177 & 288 & 342 \\
\hline to water, in feet....... & 215 & 161 & 257 & 187 & 314 & 346 \\
\hline $\begin{array}{l}\text { Elastic specific } \\
\text { storage for aquitards, }\end{array}$ & $69 \times 10^{-6}$ & $38 \times 10^{-6}$ & $0 \times 10^{-6}$ & $5 \operatorname{lr}^{-6}-6$ & $0=10^{-6}$ & $0-10^{-5}$ \\
\hline In feet $\ldots \ldots \ldots \cdots \cdots \cdots \cdots \cdots$ & $6.9 \times 10^{-0}$ & $3.8 \times 10^{-10}$ & $1.0 \times 10$ & $5.4 \times 10^{-0}$ & $4.8 \times 10^{-20}$ & $2.0 \times 10^{-}$ \\
\hline $\begin{array}{l}\text { storage for aquitards, } \\
\text { in feet- } 1 \ldots \ldots \ldots \ldots \ldots \ldots\end{array}$ & $4.6 \times 10^{-5}$ & $2.7 \times 10^{-4}$ & $2.1 \times 10^{-4}$ & $7.3 \times 10^{-6}$ & $8.4 \times 10^{-6}$ & $2.0 \times 10^{-5}$ \\
\hline Agregate aquifer & & & & & & \\
\hline $\begin{array}{l}\text { thickness, in feet....... } \\
\text { Elastic specific }\end{array}$ & 235 & 318 & 187 & 293 & 150 & 396 \\
\hline $\begin{array}{l}\text { storage for aquifers, } \\
\text { in feet- }{ }^{1} \ldots \ldots \ldots \ldots \ldots \ldots \\
\text { Elastic time constant. }\end{array}$ & $3.4 \times 10^{-7}$ & $3.4 \times 10^{-7}$ & $1.3 \times 10^{-6}$ & $8.3 \times 10^{-7}$ & $3.1 \times 10^{-8}$ & $2.4 \times 10^{-6}$ \\
\hline $\begin{array}{l}\text { Elastic time constant, } \\
\text { in years................. } \\
\text { Inelastic time constant. }\end{array}$ & .31 & .10 & .05 & .13 & .14 & .06 \\
\hline $\begin{array}{l}\text { in years................... } \\
\text { Mean residual simulation }\end{array}$ & 2.1 & 7.4 & 10.2 & .15 & .26 & .06 \\
\hline $\begin{array}{l}\text { error, in feet.......... } \\
\text { Residual error as percent }\end{array}$ & -.007 & -.001 & -.002 & .004 & -.0001 & -.002 \\
\hline $\begin{array}{l}\text { of net compaction........ } \\
\text { Standard deviation of }\end{array}$ & 9.6 & 1.4 & 3.9 & 13 & .5 & 25 \\
\hline residual error, in feet.. & \pm .01 & \pm .003 & \pm .005 & \pm .005 & \pm .004 & \pm .003 \\
\hline Number of error comparisons & 257 & 506 & 133 & 398 & 241 & 314 \\
\hline $\begin{array}{l}\text { Lons-term error growth, } \\
\text { in feet per year......... }\end{array}$ & $1.8 \times 10^{-3}$ & $2.3 \times 10^{-4}$ & $-1.2 \times 10^{-3}$ & $1.5 \times 10^{-3}$ & $2.3 \times 10^{-3}$ & $-4.0 \times 10^{-3}$ \\
\hline
\end{tabular}

${ }^{1}$ Cumulative thickness and depth to midplane of equivalent aquitard are reported to the nearest foot. Other quantities are given to the nearest two significant figures. The accuracy of the numbers are not related to the precision shown.

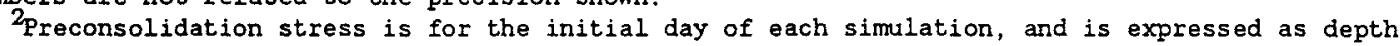
to water below land surface. The minimum value is for the center of the layer and the maximum value is for the edge of the layer. 
at wells $\mathrm{SC}-17$ and $\mathrm{B}-76$ and are close to field estimates at the remaining extensometer sites. The vertical hydraulic-conductivity model values were the same as field estimates at all model sites except for wells WR-52 and AV-25 where vertical hydraulic-conductivity values were increased during calibration.

\subsection{Sensitivity Analysis}

Sensitivity to changes in storage parameters, equivalent thickness, initial preconsolidation-stress range, vertical hydraulic conductivity, and model layering was determined for all six sites (table 3). Almost none of the sensitivity simulations showed less mean error and a smaller long-term error growth rate than the calibrated simulations. The two exceptions were increasing the equivalent thickness for the simulation for well B-76 and alterations in various aquifer parameters-increasing $\mathbf{S}_{\mathbf{s k v}}$, increasing $\mathbf{S}_{\mathbf{s k e}}$, lowering the initial preconsolidation-stress range, and decreasing elastic time constant-for simulation of well WR-52. These simulations are not conclusive until better information on layering at well B-76 is available and until the thermal error can be removed from the measured compaction data at we11 WR-52.

For data from all sites except well AV-25, simulations showed the most sensitivity to changes in the initial preconsolidationstress range. When applied to data from well AV-25, the model was most sensitive to changes in aquifer specific storage because of the large aggregate thickness of aquifers. Simulation of data from well WR-52 
was also sensitive to changes in aquitard inelastic specific storage and the elastic time constant.

Aquifer specific storage was the least sensitive parameter for wel1s SC-30, SC-17, and AF-14. For data from well B-76, the model was least sensitive to changes in aquitard elastic specific storage. For data from well WR-52, the model was least sensitive to changes in vertical hydraulic conductivity and decreasing the aquitard equivalent thickness. For data from well AV-25, the model was least sensitive to aquitard inelastic specific storage, vertical hydraulic conductivity, initial preconsolidation-stress range, and variable elastic time constant.

Model simulations were also made by summing the simulated compaction of each aquitard layer rather than using the equivalentthickness option in order to assess the difference between the equivalent-thickness geometry and actual layering. These simulations used the same parameter values from the calibrated equivalent-thickness simulations. Individual aquitard simulations used aquitard thickness and midplane depth estimated for each aquitard previously combined in the equivalent-system option. Simulations for wells SC-30 and AV-25 yielded little difference in error between these two geometric configurations, which may be due to a smaller range in aquitard thickness. Summed-layer simulations for individual layers at the remaining sites underestimated compaction, suggesting that the equivalent-system parameters may be less than actual field values for some layers or that changes in stress are greater than the measured composite heads for some layers at depth. 
Table 3.--Summary of error sensitivity for selected aquifer-system components.

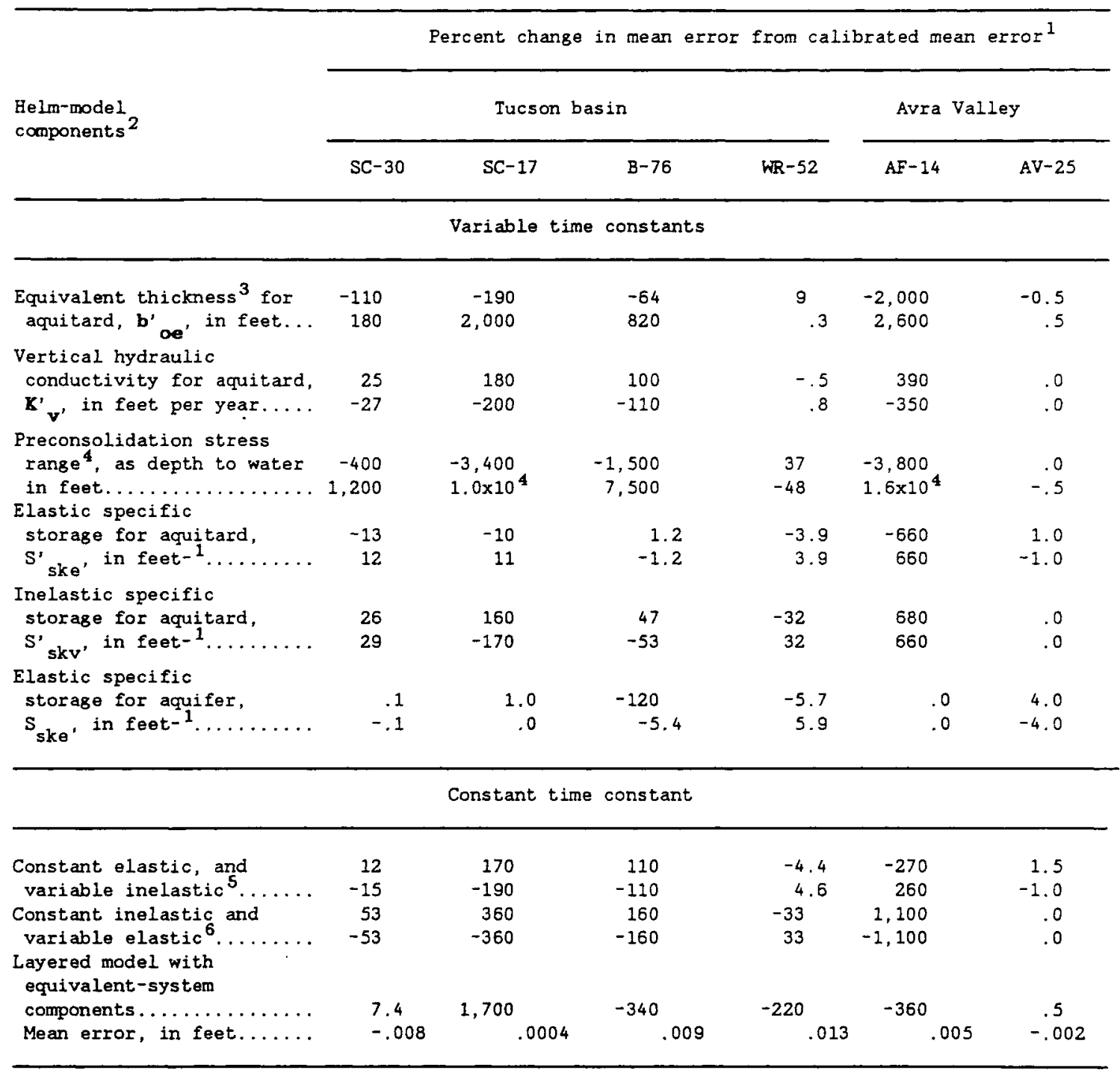

${ }^{1}$ Percent difference is difference between calibrated mean error and adjusted-conponent mean error. Plus sign denotes overestimation of compaction and minus sign denotes underestimation of compaction relative to the calibrated equivalent-thickness simulation.

Helm-model component adjusted to \pm 10 percent of the calibration value unless otherwise noted.

Equivalent thickness adjusted to \pm 20 percent of the initial calibration value and preconsolidation stress range adjusted to remain normally consolidated at $t=0$.

${ }^{4}$ Based on \pm 5 percent change in the initial calibration minimum preconsolidation stress with the maximum preconsolidation stress adjusted by the same amount.

5 Vertical hydraulic conductivity and elastic specific storage both changed with the ratio held constant.

Gertical hydraulic conductivity and inelastic specific storage both changed with the ratio held constant. 
CHAPTER 5

\section{SUMMARY}

Since the $1940^{\prime} \mathrm{s}$, ground-water declines of several feet per year induced aquifer-system compaction and land subsidence of as much as $0.5 \mathrm{ft}$ in the Tucson basin and $1.1 \mathrm{ft}$ in Avra Valley. Although overdrafts continue in both areas, ground-water declines have slowed or recovery has begun in parts of these areas since 1979-80. Vertical hydraulic gradients may result in transient seepage stresses across lower aquifers with continued declines. The upper $600 \mathrm{ft}$ of the aquifer system appears to have variable vertical gradients that are fairly constant during the simulation period. Aquifer-system compaction is affected by the preconsolidation stress, hydraulic diffusivity, layering, and stress history of the aquifer system. Layering at extensometer sites can be categorized into three general groups that typify the fine- and coarse-grained layering within the Fort Lowell Formation and upper Tinaja beds. The first group, which includes wells SC-30 and AF-14, shows almost as much elastic as inelastic compaction, a layering frequency of six layers per $100 \mathrm{ft}$, weighted-average aquitard thicknesses of 20 to $50 \mathrm{ft}$, and 30 to 75 percent clay and silt. The second group, WR-52, AV-25, C-45, and D61, shows inelastic compaction, a layering frequency of two to three layers per $100 \mathrm{ft}$, average aquitard thicknesses of less than $20 \mathrm{ft}$, and 
less than 20 percent clay and silt. The third group, SC-17 and B-76, shows inelastic compaction, a layering frequency of fewer than two layers per $100 \mathrm{ft}$, weighted-average aquitard thicknesses of more than $50 \mathrm{ft}$, and 50 to 85 percent clay and silt. The relation between compaction and size of compacting interval at wells C-45 and D-61 may indicate that most compaction between 1979 and 1986 was occurring in the shallower aquitards in this part of Tucson basin. As of 1986, the active interval of compaction generally includes the Fort Lowe11 Formation and the upper Tinaja beds. Estimated water-level declines at most extensometers are within the estimated preconsolidation-stress threshold range of 50 to $150 \mathrm{ft}$ of water-level decline.

Field and model estimates of aquitard elastic specific storage span about an order of magnitude but are comparable to values reported for Latrobe Valley, Australia, and San Joaquin Valley, California. Inelastic specific-storage values also span an order of magnitude, and the largest field values are about an order of magnitude lower than field values for aquitards in San Joaquin Valley, California. The largest model values are comparable to model values for aquitards in San Joaquin Valley, California. Low inelastic storage values at some extensometers may further indicate that the aquifer system is in transition to predominantly inelastic compaction. If so, long-term inelastic storage values may still increase before beginning to decrease because of increased compaction.

Calibration simulations of a one-dimensional, combined water-table and confined aquifer model using the equivalent-system layer option were applied to data from six extensometers in order to simulate aquifer-system compaction for periods of 2 to 6 years. 
Simulations at four of the six sites showed less than 10-percent mean error. Long-term error growth was small for all simulations, and phase-lag error was small for all simulations. Simulations were best for periods of decline and the seasonal cycles and worst for periods of sustained recovery. Calibrated hydraulic parameters were close to field estimates for most model sites. Model elastic time constants ranged between 0.06 and 0.31 years, and inelastic time constants ranged between 0.06 and 10.2 years.

Additional simulations were made to determine the sensitivity of error to changes in storage parameters, equivalent thickness, hydraulic conductivity, initial preconsolidation-stress range, and layering. Almost all simulations were most sensitive to a reduction in the initial preconsolidation stress levels and were least sensitive to changes in aquifer specific storage. Simulating compaction of individual layers and summing the results indicate that the equivalent-layers option may yield more similar results for sites with less of a range in aquitard thickness. Storage values and the single composite stress history derived from the equivalent-layers option underestimated compaction in the more realistic individual-layer configuration simulations, which suggests that either storage values are underestimated or that stress histories of the individual aquifers may be different from the composite heads used for all simulations. Because calculated compaction has not reached its ultimate value, a third alternative is that the vertical hydraulic conductivity may be what is underestimated by the equivalent-layers option. Values of vertical hydraulic conductivity are in alignment with values used elsewhere for compaction modeling, and the extreme sensitivity of the 
simulations to changes in vertical hydraulic conductivity indicate that this is not considered to be the most plausible alternative source of model-parameter error.

Initial preconsolidation-stress distribution is critical in making accurate simulations and finding accurate estimates of all model parameters. The compaction of each individual aquitard layer depends to a large extent on the stress history of the surrounding aquifers. Ideally, the stress history of each individual aquifer and the compaction history for groups of aquitards within the aquifer system and each semiconfining bed should be measured independently. These measurements should begin before the initial preconsolidation-stress threshold is reached for each part of the aquifer system.

If the estimated initial preconsolidation stress has a small error, all model parameters will have a large error during the calibration process. The error can be minimized by calibrating to historical data that represents several multiples of the time constants. Sensitivity tests indicate that varying the values of $K^{\prime}{ }^{\prime}$ ' $S^{\prime}$ ske, $S^{\prime}$ skv' and $S_{\text {ske }}$ do not affect the results as long as $p^{\prime} \max (t=0)$ is correctly distributed as a function of depth. The absolute value of $\mathbf{K}^{\prime}{ }_{\mathbf{v}}, \mathbf{S}^{\prime}{ }_{\text {ske' }}$ and $\mathbf{S}^{\prime}{ }_{\mathbf{s k v}}$ for successful calibration depends on the choice of the initial preconsolidation stress, $p^{\prime} \max (z, 0)$ when part or all of the aquifer system becomes norma1ly consolidated at some time past the initial simulation time. Conversely, if all parts of the aquifer system are at all times overconsolidated, then knowing $\mathrm{p}^{\prime} \max (\mathbf{z}, 0)$ becomes immaterial, and it becomes difficult to evaluate S'skv' Continued data collection and a postaudit of compaction simulations may 
be needed after another 6 to 10 years of data collection and would determine whether inelastic specific-storage values will continue to increase with increasing stress in the different depositional environments. The additional data also would determine what values of preconsolidation stress, inelastic specific storage, and depth intervals should be used for projections of aquifer-system compaction and land subsidence. 


\section{IIST OF REFERENCES}

Allen, T.J., 1981, The subsurface stratigraphy of the northern Avra Valley, Pima County, Arizona: Akron, Ohio, Kent State University, unpublished master's thesis, $71 \mathrm{p}$.

Anderson, S.R., 1987a, Potential for aquifer compaction, land subsidence, and earth fissures in the Tucson basin, Pima County, Arizona: U.S. Geological Survey Open-File Report 86 $482,3 \mathrm{p} 1$. , pending publication as U. S. Geological Survey Hydrologic Investigations Atlas HA-713, 4 sheets. [In press]

1987b, Cenozoic stratigraphy and geologic history of the Tucson basin, Pima County, Arizona: U. S. Geological Survey Water-Resources Investigations Report 87-4190, 20 p.

1988, Potential for aquifer compaction, land subsidence, and earth fissures in Avra Valley, Pima County, Arizona: U. S. Geological Survey Open-File Report 87-685, 4 sheets.

Anderson, S.R., and Hanson, R.T., 1987, Relation of Cenozoic depositional environments to aquifer-system compaction and 1 and subsidence [abs.], in Abstracts with Programs: Geological Society of America, Annual Meeting and Exposition, October 26 29, 1987, Phoenix, Arizona, p. 573

Anderson, S.R., Schumann, H.H., and Wallace, B.L., 1982, Progress report on measurement of aquifer compaction in the Tucson basin, in Babcock, J.A., and Hix, G.L., 1982, Annual static water-level basic data report, Tucson basin and Avra Valley, Pima County, Arizona, 1981, 1982: City of Tucson, Tucson Water Planning Division report, $21 \mathrm{p}$.

Anderson, T.W., 1972, Electrical analog analysis of the hydrologic system, Tucson basin, southeastern, Arizona: U.S. Geological Survey Water-Supply Paper 1939-C, 34 p.

1980, Study plan for the regional aquifer-system analysis of alluvial basins in south-central Arizona and adjacent States: U.S. Geological Survey Open-File Report 80-1197, 22 p.

1983, Implications of deep percolation to ground-water systems in south-central Arizona and adjacent States, in Proceedings of the 1983 Deep Percolation Symposium, October 26, 1982: Arizona Department of Water Resources Report 4, 84 p.

Babcock, J.A., Cameron, J.A., and Andrews, John, 1984, Annual static water-level basic data report, Tucson basin and Avra Valley, Pima County Arizona, 1983: City of Tucson, Tucson Water Planning Division report, $45 \mathrm{p}$. 
Babcock, J.A., Cameron, J.A., and Heidenreich, L.K., 1986, Annua1 static water level basic data report Tucson basin and Avra Valley, Pima County, Arizona, 1985: City of Tucson, Tucson Water Planning Division report, $57 \mathrm{p}$.

Babcock, J.A., and Hix, G.L., 1982, Annual static water-level basic data report, Tucson basin and Avra Valley, Pima County, Arizona, 1981: City of Tucson, Tucson Water Planning Division report, $21 \mathrm{p}$.

Burkham, D.E., 1970, Depletion of streamflow by infiltration in the main channels of the Tucson basin, southeastern Arizona: U.S. Geological Survey Water-Supply Paper 1939-B, 36 p.

Caito, T.J., and Sogge, R.L., 1982, Fissuring and subsidence in Avra Valley, Arizona: Tucson, Arizona, Desert Earth Engineering prepared in cooperation with City of Tucson and Pima County, Department of Transportation, $69 \mathrm{p}$.

Clifton, P.M., 1981, Statistical inverse modeling and geostatistical analysis of the Avra Valley aquifer: Tucson, Arizona, University of Arizona master's thesis, 190 p.

Clyma, W., Rebuck, E.C., and Show, R.J., 1968, Hydraulic properties of the Tucson basin from short-term pumping tests: American Society of Agricultural Engineers Paper PC68-105, 17 p.

Condes de la Torre, Alberto, 1970, Streamflow in the upper Santa Cruz River basin, Santa Cruz and Pima Counties, Arizona: U.S. Geological Survey Water-Supply Paper 1939-A, 26 p.

Cuff, M.K., and Anderson, S.R., 1987, Ground-water conditions in Avra Valley, Pima and Pinal Counties, Arizona: U.S. Geological Survey Water-Resources Investigations 87-4192, 3 sheets.

Davidson, E.S., 1973, Geohydrology and water resources of the Tucson basin, Arizona: U.S. Geological Survey Water-Supply Paper $1939-\mathrm{E}, 81 \mathrm{p}$.

Eberly, L.D., and Stanley, T.B., Jr., 1978, Cenezoic stratigraphy and geologic history of southwestern Arizona: Geological Society of America Bulletin, v. 89, p. 921-940.

Fenneman, N.M., 1931, Physiography of Western United States: New York, McGraw-Hill Book Co., 534 p.

Freethey, G.W., 1986, Considerations in modeling ground-water flow in the alluvial basins of Arizona, in Anderson, T.W., and Johnson, I.A., editors., Regional aquifer systems of the United States, Southwest alluvial basins of Arizona: American Water Resources Association Monograph Series 7, p. 57-67.

Freeze, R.A., and Cherry, J.A., 1979, Groundwater: Englewood Cliffs, New Jersey, Prentice-Hall, 604 p. 
Helm, D.C., 1974, Evaluation of stress-dependent aquitard parameters by simulating observed compaction from known stress history: Berkeley, California, University of California, doctoral dissertation, $175 \mathrm{p}$.

1975, One-dimensional simulation of aquifer-system compaction near Pixley, California. 1, Constant paramters: American Geophysical Union, Water Resources Research, v. 11, no. 3, p. 465-478.

1976, One-dimensional simulation of aquifer-system compaction near Pixley, California. 2, Stress-dependent parameters: American Geophysical Union, Water Resources Research, v. 12, no. 3, p. $375-391$.

1977, Estimating paramters of compacting fine-grained interbeds within a confined aquifer system of one-dimensional simulation of field observations, in International Symposium on Land Subsidence, 2d, Anaheim, California 1976, Proceedings: International Association of Hydrological Sciences Publication 121 , p. $145-156$.

1978, Field verification of a one-dimensional mathematical model for transient compaction and expansion of a confined aquifer system, in Specialty Conference on Verification of Mathematical and Physical Models in Hydraulic Engineering: College Park, Maryland, American Society of Civil Engineers Proceedings, p. 189-196.

1984, Latrobe Valley subsidence predictions-The modeling of time-dependent ground movement due to groundwater withdrawal: State Electricity Commission of Victoria, Fuel Department and Design Engineering and Environment Department, 2 volumes, v.p.

Holtz, R.D., and Kovacs, W.D., 1981, An introduction to geotechnical engineering: Englewood Cliffs, New Jersey, Prentice-Hall, 733 p.

Holzer, T.L., 1981, Preconsolidation stress of aquifer systems in areas of induced land subsidence: American Geophysical Union, Water Resources Research, v. 17, no. 3, p. 693-704.

Ireland, R.L., Poland, J.F., and Riley, F.S., 1982, Land subsidence in the San Joaquin Valley, California, as of 1980: U.S. Geological Survey Professional Paper 437-I, 93 p.

Johnson, P.W., 1952, Upper Santa Cruz basin, Pima and Santa Cruz Counties, in Halpenney, L.C. and others, Ground water in the Gila River basin and adjacent areas, Arizona-A summary: U.S. Geological Survey open-file report, p. 101-114.

Jorgensen, D.G., 1980, Relationships between basic soils-engineering equations and basic ground-water flow equations: U.S. Geological Survey Water-Supply Paper 2064, 40 p. 
Lambe, T.W., and Whitman, R.V., 1969, Soil mechanics: New York, John Wiley and Sons, Inc., 553 p.

Laney, R.L., 1972, Chemical quality of the water in the Tucson basin, Arizona: U.S. Geological Survey Water-Supply Paper 1939-D, 46 p.

Laney, R.L., and Davidson, C.B., 1986, Aquifer-nomenclature guidelines: U.S. Geological Survey Open-File Report 86-534, 46 p.

Leake, S.A., and Hanson, R.T., 1986, Distribution and movement of trichloroethylene in ground water in the Tucson area, Arizona: U.S. Geological Survey Water Resources Investigations Report $86-4313,61 \mathrm{p}$.

Lofgren, B.E., 1968, Analysis of stresses causing land subsidence, in Geological Survey Research, 1968: U.S.Geological Survey Professional Paper 600-B, p. B219-B225.

Mock, P.A., Travers, B.C., and Williams, C.K., 1985, Results of the Tucson Airport area remedial investigation, Phase I, Volume 2, Contaminant transport modeling: Arizona Department of Water Resources duplicated report, $106 \mathrm{p}$.

Moosburner, Otto, 1972, Analysis of the ground-water system by electrical-analog model, Avra Valley, Pima and Pinal Counties, Arizona: U.S. Geological Survey Hydrologic Investigations Atlas $\mathrm{HA}-215,2$ sheets

Neuman, S.P., Preller, C., and Narasimhan, T.N., 1982, Adaptive explicit-implicit quasi three-dimensional finite element mode1 of flow and subsidence in multiaquifer systems: American Geophysical Union, Water Resources Research, v. 18, no. 5, p. 1551-1561.

Neuman, S.P., and Witherspoon, P.A., 1969, Theory of flow in a confined two-aquifer system: American Geophysical Union, Water Resources Research, v. 5, no. 4, p. 803-816.

Oppenheimer, J.M., and Sumner, J.S., 1980, Depth-to-bedrock map of southern Arizona: University of Arizona, Laboratory of Geophysics, Department of Geosciences, 1 sheet.

Platt, W.S., 1963, Land-surface subsidence in the Tucson area: University of Arizona, Department of Geology master's thesis, $38 \mathrm{p}$.

Poland, J.F., Lofgren, B.E., Ireland, R.L., and Pugh, R.G., 1975, Land subsidence in the San Joaquin Valley, California, as of 1972: U.S.Geological Survey Professional Paper 437-H, $78 \mathrm{p}$. 
Poland, J.F., Lofgren, B.E., and Riley, F.S., 1972, Glossary of selected terms useful in studies of the mechanics of aquifer systems and land subsidence due to fluid withdrawal: U.S. Geological Survey Water-Supply Paper 2025, 9 p.

Pool, D.R., 1984, Aquifer geology of alluvial basins of Arizona, in Replogle, J.A., and Renard, K.G., editors., Water today and tomorrow: American Society of Civil Engineers, Proceedings of the 1984 Irrigation and Drainage Specialty Conference, Flagstaff, Arizona, July 24-26, 1984, p. 683-690.

Rampe, J.J., 1985, Results of the Tucson Airport area remedial investigation, Phase I, Volume 3 , An evaluation of the potential sources of groundwater contaminantion near the Tucson International Airport, Tucson, Arizona: Arizona Department of Health Services duplicated report, $110 \mathrm{p}$.

Reeter, R.W., and Cady, C.V., 1982, Maps showing ground-water conditions in the Avra-Altar Valley area, Pima and Santa Cruz Counties, Arizona: Arizona Department of Water Resources Hydrologic Map Series Report Number 7, 2 sheets.

Remson, I., Homberger, G.M., and Molz, F.J., 1971, Numerical methods in subsurface hydrology: New York, John Wiley and Sos, Inc., $389 \mathrm{p}$.

Riley, F.S., 1969, Analysis of borehole extensometer data from central California, in Tison, L.J., editor, Land subsidence: Tokoyo, International Association of Scientific Hydrology Publication 89 , v. 2, p. 423-431.

1984, Developments in borehole extensometry, in International Symposium on Land Subsidence, 3d, Venice, Italy, 1984, Proceedings: International Association of Hydrological Sciences Publication 151, p. 169-186

Schmidt, K.D., 1985, Results of the Tucson Airport area remedial investigation, Phase I, Volume 1, Summary report: Arizona Department of Health Services duplicated report, 114 p.

Schwalen, H.C., and Shaw, R.J., 1957, Ground water supplies of Santa Cruz Valley of southern Arizona between Rillito Station and the international boundary: University of Arizona, Agriculteral Experiment Station Technical Bulletin 288, 119 p.

Scott, R.F., 1963, Principles of soil mechanics: Palo Alto, AddisonWesley, $550 \mathrm{p}$.

Smith, G.E.P., 1938, The physiography of Arizona valleys and the occurrence of ground water: University of Arizona, College of Agriculture Experiment Station Technical Bulletin 77, 91 p. 
Strange, W.E., 1983, Subsidence monitoring for State of Arizona:

National Oceanic and Atmospheric Administration report, $74 \mathrm{p}$.

Terzaghi, K., 1943, Theoretical soil mechanics: New York, John Wiley and Sons, Inc., $510 \mathrm{p}$.

Travers, B.C., and Mock, P.A., 1984, Groundwater modeling study of the Upper Santa Cruz basin and Avra Valley in Pima and Santa Cruz Counties, southeastern Arizona: Arizona Department of Water Resources, Hydrologic Division, 2 volumes, v.p.

Tucci, Patrick, and Pool, D.R., 1986, Use of geophysics for geohydrologic studies in the alluvial basins of Arizona, in Anderson, T.W., and Johnson, I.A., editors., Regional aquifer systems of the United States, Southwest alluvial basins of Arizona: American Water Resources Association Monograph Series 7 , p. $37-56$.

Tucci, Patrick, Schmoker, J.W., and Robbins, S.L., 1982, Boreholegravity surveys in basin-fill deposits of central and southern Arizona: U.S. Geological Survey Open-File Report 82-473, 23 p.

Turner, S.F., 1946, Ground water in the Tucson quadrangle, Arizona: U.S. Geological Survey open-file report, $15 \mathrm{p}$.

Turner, S.F., and others, 1943, Ground-water resources of the Santa Cruz basin, Arizona: U.S. Geological Survey open-file report, 84 p.

1947, Further investigations of the ground-water resources of the Santa Cruz basin, Arizona: U.S. Geological Survey open-file report, $45 \mathrm{p}$.

U.S. Environmental Protection Agency, 1984, Final determination of ground water system of the Upper Santa Cruz basin and AvraAltar basin of Pima, Pinal, and Santa Cruz Counties, Arizona-Aquifer Determination: Federal Register, v. 49, no. 16, OWFRL-2511-3, p. 2948-2950.

Whallon, A.J., 1983, A geohydrologic study of the regional ground-water system in Avra Valley, Pima and Pinal Counties, Arizona: Tucson, Arizona, University of Arizona, master's thesis, $68 \mathrm{p}$.

White, N.D., Matlock, W.G., and Schwalen, H.C., 1966, An appraisal of the ground-water resources of Avra and Altar Valleys: Arizona State Land Department Water-Resources Report 25, 66 p.

Wilson, E.D., Moore, R.T., and Cooper, J.R., 1969, Geologic map of Arizona: Arizona Bureau of Mines map, scale 1:500,000.

Winikka, C.C., 1984, A view of subsidence: Arizona Bureau of Geology and Mineral Technology Fieldnotes, v. 14, no. 3, p. 1-5. 
Wrege, B.M., Schumann, H.H., and Wallace, B.L., 1985, Geohydrologic data along the Tucson aqueduct of the Central Arizona Project in Pinal and Pima Counties, Arizona: U.S. Geological Survey Open-File Report 85-565, 77 p. 